Pharmacognosy Program

Doctoral School of Pharmaceutical Sciences

University of Szeged

\title{
Isolation and structure elucidation of bioactive compounds from Euphorbia species
}

Ph.D. Thesis

Norbert Kúsz

Supervisors:

Prof. Judit Hohmann

Dr. Dóra Rédei

Szeged, Hungary 


\section{Table of contents}

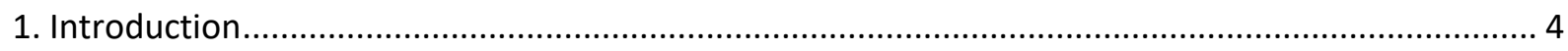

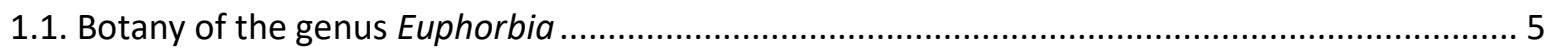

1.1.1. Taxonomic classification of the investigated Euphorbia species ........................................ 5

1.1.2. Botanical description of the investigated Euphorbia species............................................. 6

1.2. Chemical composition of the latex of Euphorbia species, and its role in plant defence ............. 7

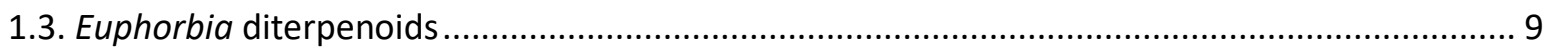

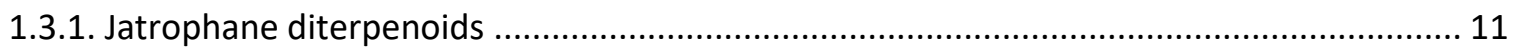

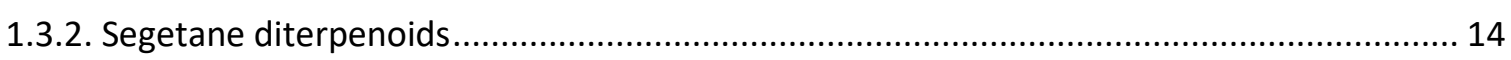

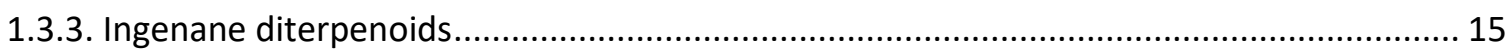

1.4. Chemistry and folk medicinal use of the investigated Euphorbia species ............................... 16

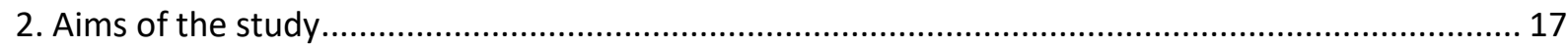

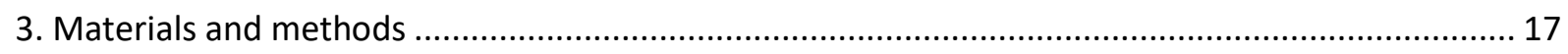

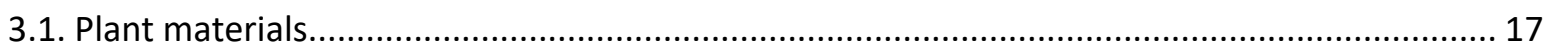

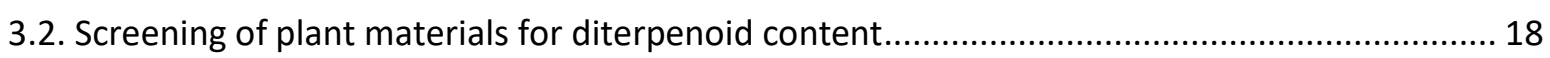

3.3. Extraction and isolation, and preparation of plant extracts .................................................. 18

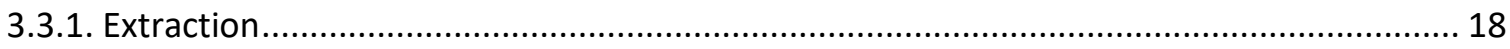

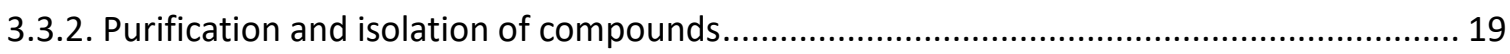

3.3.3. Preparation of plant extracts for pharmacological screening ........................................... 21

3.4. Characterization and structure determination of the isolated compounds .............................. 21

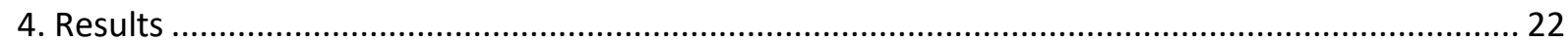

4.1. Screening of E. dulcis, E. taurinenis, and E. davidii for diterpenoid contents ......................... 22

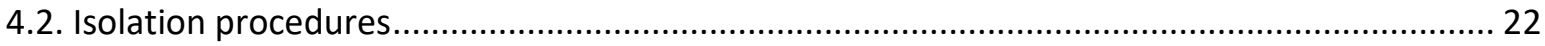

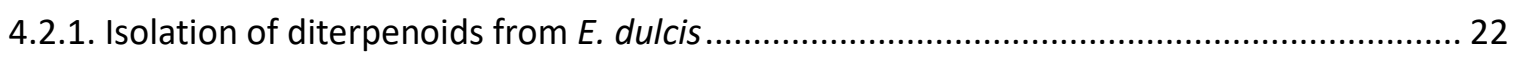

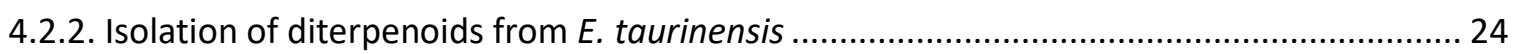

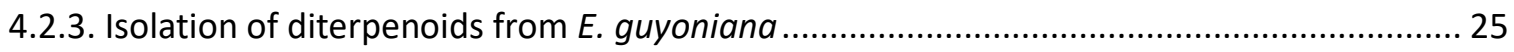

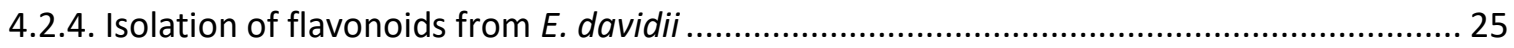

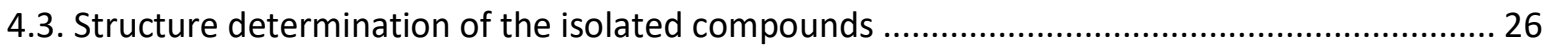

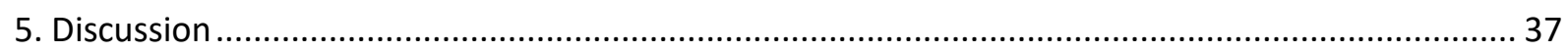

5.1. Isolation and purification of the diterpenoids and flavonoid glycosides ................................. 38

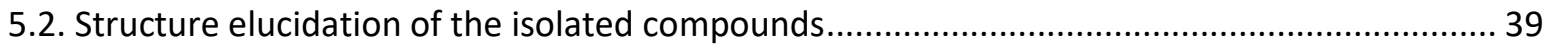

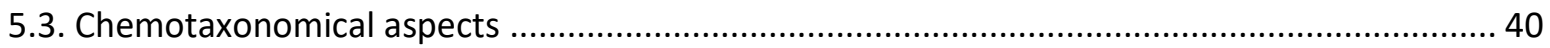

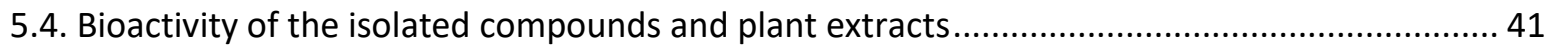

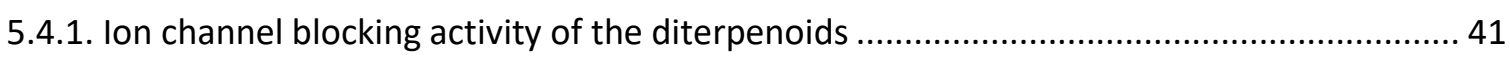

5.4.2. MDR-reversing and cytotoxic activities of diterpenoids isolated from E. taurinensis ........ 43

5.4.3. Antiproliferative activities of the extracts of $E$. davidii ..................................................... 45

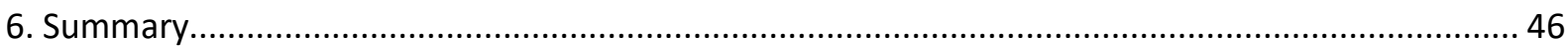

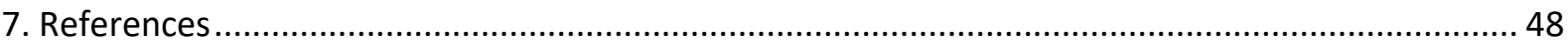




\section{Abbreviations and symbols}

$1 \mathrm{D}$

2D two-dimensional

CC column chromatography

COSY correlated spectroscopy

$\delta \quad$ chemical shift

fr fraction

GIRK G protein-gated inwardly rectifying potassium channels

hERG human ether-a-go-go-related gene

HMBC heteronuclear multiple-bond correlation spectroscopy

$\mathrm{HSQC}$ heteronuclear single-quantum coherence spectroscopy

HPLC high-performance liquid chromatography

HRESIMS high-resolution electrospray ionization mass spectroscopy

JMOD J-modulated spin-echo experiment

MDR multidrug resistance

NOE nuclear Overhauser effect

NOESY nuclear Overhauser effect spectroscopy

NP normal-phase

OCC open-column chromatography

P-gp permeability glycoprotein

PKC protein kinase $\mathrm{C}$

PLC preparative-layer chromatography

$R_{f} \quad$ retention factor

RP reversed-phase

SEM standard error of the mean

TLC thin-layer chromatography

$t_{R} \quad$ retention time

VLC vacuum-liquid chromatography

Ac acetyl

$\mathrm{Bz}$ benzoyl

Cin cinnamoyl

iBu. isobutyryl

AcOAc acetoxyacetyl

Tig tigloyl 


\section{Introduction}

The genus Euphorbia belongs to the Euphorbiaceae family, which comprises 5 subfamilies, about 50 tribes, 300 genera, and 8000 species. ${ }^{1}$ Euphorbia is among the largest genera of flowering plants with approximately 2000 recognized species. ${ }^{2}$ Plants of this nearly cosmopolitan genus grow throughout the world, except in cold, harsh alpine and arctic regions. A comprehensive work written in the last decade described 29 Euphorbia species in the Hungarian flora. ${ }^{3}$ Since then, other invasive Euphorbia plants (e.g. Euphorbia davidii, E. serpens, E. prostrata) have also appeared in disturbed habitats of the country. ${ }^{4-6}$ The remarkably diverse growth forms - including geophytes, herbs, shrubs, understory and canopy trees, and an array of succulent and xerophytic plants - are the result of evolutionary adaptations to different environmental challenges, and serve as a hallmark of the genus. ${ }^{7}$

Members of the genus Euphorbia can be characterized by the frequent occurrence of white, milky latex. The presence of the exudate is supposed to provide protection against herbivores, insects, and microbial phytopathogens. ${ }^{8}$ Some Euphorbias, such as E. esula, are listed by local authorities as noxious weeds, and are required to be eradicated from both public and private properties because of their capability to kill livestock. ${ }^{9}$ In the first edition of Species Plantarum (1753), Carl Linnaeus named the genus after an ancient Greek physician, Euphorbus, who successfully treated the severe constipation of his king (Juba II, King of Numidia) with the dried sap of a succulent species. ${ }^{1}$ Many authors believe that the plant described in ancient texts as growing abundantly on the slopes of the Atlas Mountains was E. resinifera.${ }^{10}$ Euphorbia species are collectively known as "spurges". Their name has been derived from the Medieval French word "epurger" ("expurgare" in Latin), referring to the purgative activity of the latex and seeds. ${ }^{11}$

The traditional medicinal uses of spurge species have a long and rich history. Spurges are commonly used in folk medicine for the treatment of microbial (e.g. gonorrhoea, syphilis) and parasitic infections, obstipation, asthma, coughs, rheumatism, snakebites, wounds and haemorrhages, eczema, sores, warts, and other skin disorders. ${ }^{12}$ Furthermore, the preparations of "euphorbium" - the sticky gum of E. resinifera - have been used against cancers since at least the time of Hippocrates, Galen, and Dioscorides. ${ }^{10}$ Some species (E. kansui, E. pekinensis, E. lathyris, E. humifusa, E. maculata, E. hirta, E. ebracteolata, E. fischeriana) have been acknowledged in Chinese pharmacopoeias as valuable herbal remedies. ${ }^{13-15}$ The genus contains many plants of economic importance, such as E. tetragonal and E. triangularis (inferior rubber), E. resinifera (euphorbium), E. intisy (intisy rubber), and E. antisyphylitica (candelilla wax, E 902). ${ }^{16}$ Last but not least, some Euphorbia species are cultivated as ornamentals, for instance E. pulcherrima (poinsettia, Christmas flower), which is widely used for decorating houses during the festive season of Christmas. 
In the recent years growing attention has been paid to the diterpenoids, a major class of natural products of spurge species. Due to their structural variability and promising bioactivities, Euphorbia diterpenoids provide great opportunities for the development of novel drug candidates. In 1995, Hohmann et al. (Department of Pharmacognosy, University of Szeged) initiated a research project with the aim of investigating the secondary metabolites of Euphorbia species. In the course of those studies, a fast and reliable screening method was developed for the detection of diterpenoids, and several diterpenoid esters with different skeletons were isolated. ${ }^{17-38}$ The present thesis summarizes the results of the phytochemical analysis of E. dulcis, E. taurinensis, E. guyoniana, and E. davidii, with particular focus on their diterpenoid contents.

\subsection{Botany of the genus Euphorbia}

The genus Euphorbia is renowned as one of the most diverse groups of the family Euphorbiaceae. Despite the highly modified growth forms, all plants in the genus can be characterized by a distinctive synapomorphy called as cyathium. The cyathium is a monoecious inflorescence, which name originates from the Greek word "kyathos" meaning "cup" or "dipper". ${ }^{39}$ The structure of cyathium indeed has a cup-like shape, and is composed of an involucre formed by fused bracts, and a single, terminal stalked gynoecium (interpreted as a perianthless female flower) surrounded by 4 or 5 lateral clusters of stamens (interpreted as reduced male flowers). A series of (usually 4 or 5) nectar-secreting gland located at the rim of the cyathial involucre is responsible for attracting pollinators. ${ }^{40}$

\subsubsection{Taxonomic classification of the investigated Euphorbia species}

\begin{tabular}{|c|c|c|c|c|}
\hline Order & \multicolumn{4}{|c|}{ Euphorbiales } \\
\hline Family & \multicolumn{4}{|c|}{ Euphorbiaceae } \\
\hline Subfamily & \multicolumn{4}{|c|}{ Euphorbioideae } \\
\hline Tribe & \multicolumn{4}{|c|}{ Euphorbieae } \\
\hline Subtribe & \multicolumn{4}{|c|}{ Euphorbiinae } \\
\hline Genus & \multicolumn{4}{|c|}{ Euphorbia } \\
\hline Subgenus & \multicolumn{3}{|c|}{ Esula Pers. } & Chamaesyce Raf. \\
\hline Section & Helioscopia Dumort. & Paralias Dumort. & $\begin{array}{l}\text { Guyonianae } \\
\text { Molero \& Riina }\end{array}$ & $\begin{array}{c}\text { Poinsettia } \\
\text { (Graham) Baill. }\end{array}$ \\
\hline Subsection & - & - & - & Stormieae Croizat \\
\hline Species & E. dulcis $\mathrm{L}^{41}$ & E. taurinensis All. ${ }^{41}$ & $\begin{array}{l}\text { E. guyoniana } \\
\text { Boiss. \& Reut. }{ }^{41}\end{array}$ & E. davidii Subils. ${ }^{42}$ \\
\hline
\end{tabular}

The giant genus Euphorbia includes four subgenera: E. subg. Esula Pers., E. subg. Euphorbia, E. subg. Chamaesyce Raf., and E. subg. Athymalus Neck. ex Rchb. (also known as E. subg. Rhizanthium (Boiss.) 
Wheeler)..$^{41}$ The "leafy spurges" term is often used to describe subgenus Esula, because leafy herbaceous plants are predominant in this taxon. The subgenus comprises about 480 species, which are distributed through Eurasia, but some of its members also occur in Africa and in the New World. Subgenus Chamaesyce is the second-most species-rich after subgenus Euphorbia..$^{42}$ It contains around 600 species worldwide, and encompasses the largest New World radiation of the genus. Plants in subgenus Athymalus (about 150 species) are mostly succulents growing in Africa. Subgenus Euphorbia (> 600 species) is especially diverse in the arid and semi-arid regions of tropics and subtropics, and is well-known for its cactus-like, succulent representatives. ${ }^{7}$

\subsubsection{Botanical description of the investigated Euphorbia species}

Euphorbia dulcis L. (sweet spurge, syn. Euphorbia alpigena A.Kern., E. cordata Schrank, E. deseglisei Boreau ex Boiss., E. fallax Hagenb., E. hiberna Lepech., E. incompta Ces., E. lanuginosa Lam., E. patens Kit., E. purpurata Thuill., E. solisequa Rchb., E. viridiflora Waldst. \& Kit., Galarhoeus dulcis (L.) Haw., Pythius dulcis (L.) Raf., Tithymalus alpigena (A.Kern.) Woerl., T. deseglisei (Boreau ex Boiss.) Soják, T. dulcis Scop. ${ }^{*}$ ) is a more or less pubescent perennial herb with a height of $20-50 \mathrm{~cm}$. The rhizomes are long, thicker than the stems, fleshy, swollen, and jointed. The stems are slender, terete, scaly at their base, and are approximately $2 \mathrm{~mm}$ in diameter. Usually 4-8 axillary rays can be found on a single stem. The leaves are 25-70 $\mathrm{mm}$ long and have elliptical to oblong shape. The ray-leaves are shorter than the rays, like the cauline but wider. The raylet-leaves are triangular-shaped, sub-cordate, and serratededged. The capsules measure 3 to $4 \mathrm{~mm}$ in length, are deeply sulcate, glabrous or pubescent, and irregularly and sometimes sparsely covered with cylindrical and hemispherical tubercles. The tubercles are often filiform. The seeds are $2 \times 3$ to $2 \times 6 \mathrm{~mm}$, smooth, and dark brown. The species occurs in the damp and shady places of West and Central Europe and extends southwards to Central Italy and Macedonia. ${ }^{43}$

Euphorbia taurinensis All. (syn. Esula taurinensis (All.) Fourr., Euphorbia dalmatica Vis., E. graeca Boiss. \& Spruner, E. lagascae Spruner ex Nyman, E. preslii Spruner ex Nyman, E. serbica Formánek, Tithymalus graecus (Boiss. \& Spruner) Klotzsch \& Garcke, T. taurinensis (All.) Klotzsch \& Garcke) is a glabrous annual herb with a height of $15 \mathrm{~cm}$. The stems are simple or bear 2 branches at the base, with up to 6 axillary rays. The shortly petiolate, linear or oblanceolate shaped, entire leaves measure $2-3 \mathrm{~cm}$ in length and 3.5-5 mm in width. Raylet-leaves are somewhat obliquely rhombic or trullate, acute, and subentire. The rays are often much-branched. The capsules are $3 \times 3.5 \mathrm{~mm}$, shallowly sulcate, and finely granulated on the keels. The seeds are 1.8-2 $\mathrm{mm}$ long, ovoid shaped, rather deeply pitted,

\footnotetext{
* synonym names of plants in the thesis are found at http://www.theplantlist.org/
} 
greyish-white with dark grey discoloration in the pits. This invasive species is native in southern parts of Europe and has been introduced into Central and North Europe as well. ${ }^{43}$

Euphorbia guyoniana Boiss. \& Reut. (syn. Tithymalus guyonianus (Boiss. \& Reut.) Klotzsch \& Garcke) is a dark green herbaceous, glabrous, deciduous plant. The branchy, ascending or erect stems are usually 30-50 cm tall, but sometimes they can reach up to $1 \mathrm{~m}$ in height. Leaves are narrow, linear, alternate, the leaf apex is acute or obtuse, and gradually tapers to the tip. As a hemicryptophyte, the plant produces perennating buds in order to survive unfavourable conditions. The leaves are often absent on the flowering branches, and rapidly dry out at the onset of drought. It has an umbel with 2-3 (rarely 4-5) rays. Bracts are small and are oval or rhomboid shaped. The smooth capsules are $4 \times 5 \mathrm{~mm}$, globular, depressed, smooth capsules and have deep longitudinal grooves on their surface. ${ }^{44,45}$ The ecarunculate seeds are ovoid, whitish or greyish, covered by longitudinal denticulate-lacerate wings of arillate origin. E. guyoniana grows on sandy dunes on the northern edge of the Saharan Desert and is distributed from Morocco to Libya. ${ }^{41}$

Euphorbia davidii Subils. (toothed spurge, syn. E. dentata var. gracillima Millsp., E. dentata var. lancifolia Farw.) is an annual herb. The stems are solitary, erect, 20-70 cm tall, coarsely or sparsely hirsute, and closely strigillose. The branches are usually straight, while the proximal branches are occasionally arcuate. The leave blades are 1-10 cm long and 5-35 mm wide, usually stand opposite, and sometimes alternate at distal nodes. They have lanceolate to broadly elliptic shape. Ray-leaves are narrowly elliptic to lanceolate, shortly petiolate, and paler at their base. The glabrous, 3-lobed, broadly ovoid capsules measure 2.9-3.3 $\times$ 4-4.8 $\mathrm{mm}$. The seeds display ovoid or triangular-ovoid shape, measure 2.4-2.9 $\times$ 2.2-2.9 mm in size, angular in cross-section, irregularly tuberculate, and have black, brown, or pale grey colour. E. davidii Subils. and E. dentata Michx. (David's spurge) belong to the $E$. dentata aggregate, and sometimes grow sympatrically. These plants have been widely misidentified due to the similarities in their morphology, and because of the recent recognition of $E$. davidii as a separate species. The agricultural weed $E$. davidii is native in the southwestern United States and northern Mexico, elsewhere is adventive; in Europe it has dozens of dispersed populations throughout the continent. ${ }^{4,46}$

\subsection{Chemical composition of the latex of Euphorbia species, and its role in plant defence}

Latex is considered to be the most intriguing part of Euphorbia species from the point of view of natural product discovery. This aqueous emulsion or suspension is secreted into vacuoles of specialized cells called laticifers and contains complex mixtures of pharmacologically active compounds including terpenoids, proteins, carbohydrates, and amino acids. The latex is held under pressure, and immediately oozes out in case of an injury. Previously, several hypotheses have been proposed to 
explain the function of latex, like storage of plant nutrients, deposit of waste products, or water reserve. Nowadays it is generally accepted that latex plays a major role in plant self-defence mechanisms.$^{47}$ Latices often contain specialized defensive metabolites at much higher concentrations compared to other plant organs. ${ }^{48}$ This fact, along with the localization of toxic diterpenoids to young stems and roots, strongly supports this theory. ${ }^{49}$

Serine and cysteine proteases are frequently present in the latex of Euphorbia species. ${ }^{50}$ They are considered to promote coagulation processes after an injury, and therefore the formed clot could prevent infections by sealing the damaged area. Due to the procoagulant activity of these enzymes, Euphorbia latices have traditionally been applied to fresh cuts in order to stop bleeding. ${ }^{51}$ The so-called pathogenesis-related proteins, involving lysozyme and various chitinases are de novo synthesized under stressful conditions, and serve the purpose of overcoming attacks of pathogens, drought, or wounding. ${ }^{52}$ Lectins with selective affinity for particular sugar molecules represent a further fraction of proteins in the sap. A galactose-specific lectin purified from the latex of E. antiquorum is reported to exert bacteriostatic activity by binding to carbohydrates of the bacterial cell wall, which results in drastic changes in cell morphology. ${ }^{53}$

The stickiness of latices stems from the presence of polyisoprenoids which, together with proteolytic enzymes, enable rapid wound closure. The viscous latex also acts as a physical barrier against insects by deterring or trapping them. Rubber built up by cis-1,4-isoprene units is one of the most abundant polymeric terpenoid in spurge species. ${ }^{54} \mathrm{Di}$ - and triterpenoids are also major components of the latex. Bigonija et al. analysed the chemical composition of the latex from E. neriifolia, and reported total diand triterpenoid contents of the solid particles of $24.50 \%$ and $16.23 \%$, respectively. ${ }^{55}$ Triterpenoids isolated from Euphorbia latices to date are mostly tetracyclic euphanes, tirucallanes, and cycloartane derivatives, ${ }^{56,57}$ although some spiro- ${ }^{58}$ seco- ${ }^{56}$ and acyclic compounds ${ }^{59}$ have also been identified. Despite the considerable amounts of triterpenoids in rubbery latices, their contribution to the plant's defence mechanisms remains to be determined. Nevertheless, it has been shown that triterpenoids are able to incorporate into the lipid bilayer of cell membranes. ${ }^{60}$ This might increase membrane permeability of phytopathogens for smaller toxic hydrophilic (e.g. phenolic) compounds. ${ }^{54}$ Smaller isoprenoids, such as sesquiterpene hydrocarbons ( $\beta$-caryophyllene, $\alpha$-humulene, $\alpha$-copaene $)^{61}$ and dihydroionol-type bisnorsesquiterpenoids ${ }^{62}$ were reported from the latex of some spurges.

Diterpenoids represent the most diverse group of secondary metabolites of Euphorbia plants. Without being exhaustive, diterpenoids have been described to possess antifungal, ${ }^{63,64}$ antifeedant, $^{65}$ and molluscicidal ${ }^{66}$ activities. Krstić et al. have recently investigated the fungal infection-induced metabolic changes in the latex of E. palustris. ${ }^{67}$ It was found that the concentrations of antifungal metabolites, benzoyl ingenol-laurate and 24-methylenecycloartanol, increased in the infected plants; notably, the level of benzoyl ingenol-laurate was 20 -fold higher compared to healthy plants. In addition, tigliane, 
daphnane, and ingenane diterpenoids, collectively referred to as "phorboids", exhibit strong skin- and mucosa-irritating and pro-inflammatory activities. ${ }^{68}$ Besides phorboids, ${ }^{69-74}$ jatrophane, ${ }^{75-85}$ lathyrane, ${ }^{70,86}$ ingol, ${ }^{70,87,88}$ and rhamnopholane ${ }^{87}$ diterpenoids were also isolated from the latices.

\subsection{Euphorbia diterpenoids}

Spurge species are prolific producers of a diverse range of diterpenoids, which can be broadly classified into two main groups: 'higher diterpenes' are formed from the common precursor geranylgeranyl pyrophosphate (GGPP) through classical, concertina-like cyclizations typical of many triterpenoids and steroids, while 'lower diterpenes' are derived by cyclizations after the loss of a diphosphate group and alkylation one of the double bonds. ${ }^{89}$ In the genus Euphorbia higher diterpenes are mainly represented by labdanes, kauranes, atisanes, pimaranes, and abietanes. In contrast to non-specific higher diterpenes, lower diterpenes (also known as macrocyclic diterpenes) are not widely distributed in the plant kingdom. Cembrane diterpenes mainly occur in members of Euphorbia and Nicotiana genera, in the oleoresins of Pinus species, and in various marine organisms (soft corals, etc.). ${ }^{90}$ Cyclic products of the cembrane class are important chemotaxonomic markers, because their occurrence is mostly limited to the families Euphorbiaceae and Thymeleaceae. ${ }^{91}$ The blanket term 'macrocyclic diterpenes' might be deceptive, as it is used to describe compounds with actual macrocycles (e.g. jatrophanes) and their polycyclic derivatives (e.g. ingenanes) as well.

The hypothetical biosynthetic pathways of macrocyclic diterpenes are shown in Figure 1. Thanks to the studies of recently identified enzymes responsible for initiating the cyclization processes, the conversion of GGPP into casbene has been clarified. First, a reactive cembrene cation is formed from GGPP by the loss of a diphosphate moiety, then it readily undergoes cationic cyclizations and subsequent Wagner-Meerwein rearrangements. ${ }^{92}$ CYP450 enzymes catalyse a further series of oxidative reactions on the hydrocarbon backbones. ${ }^{93}$ Transannular cyclizations and ring openings, as well as esterification of the oxidized cores with a wide range of organic acids bring about unprecedented chemical diversity. However, in spite of the obvious structural similarities between macrocyclic skeletons, the production of advanced intermediates is still poorly understood.

The first known macrocyclic Euphorbia diterpenoid, euphorbiasteroid, was isolated in 1937 from the seed oil of E. lathyris. ${ }^{94}$ As its name implies, it was originally thought to be a steroid, but later the structure was unambiguously determined as 6,17-epoxy-lathyrol. ${ }^{95}$ Jatrophone, the first jatrophane 


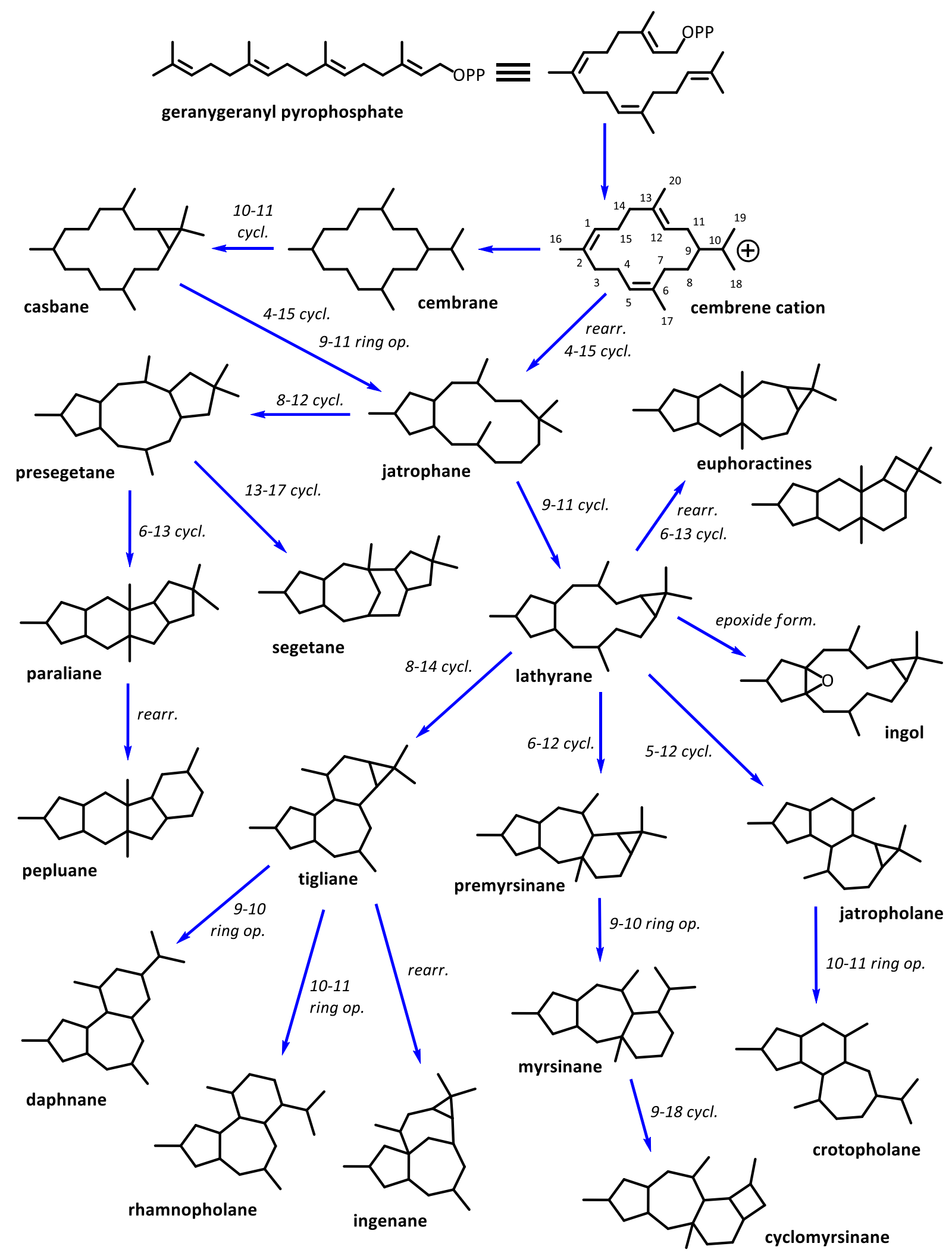

Figure 1. Plausible biosynthetic routes of macrocyclic diterpenes ${ }^{96-101}$ (cycl.: cyclization, rearr.: rearrangement, op.: opening, form.: formation). Some authors suggest that the lathyrane skeleton is directly formed from casbane by cyclization between $\mathrm{C}-4$ and $\mathrm{C}-15{ }^{68}$ (For certain macrocycles, the principles of numbering differ, thus the numbering method of jatrophanes is used here for the sake of clarity.) 
diterpenoid was discovered from Jatropha gossypiifolia in 1970. ${ }^{102}$ Ingenol, the parent compound of ingenane diterpenoids was identified in 1968 by Hecker et al. as a chemical constituent of $E$. ingens. ${ }^{94}$ Two years later the structure of its triacetate was elucidated through single-crystal X-ray analysis. ${ }^{103}$ Since that time, Euphorbia species have been the subject of extensive phytochemical investigations leading to the isolation of hundreds of new diterpene derivatives with more than 20 different skeletons. ${ }^{91}$

\subsubsection{Jatrophane diterpenoids}

Jatrophanes are synthesized in a number of Jatropha and Euphorbia species. ${ }^{104}$ These plant metabolites are characterized by a highly oxygenated trans-bicyclo[10.3.0]pentadecane skeleton wherein three methyls are located at C-2, C-6, and C-13, and a gem-dimethyl group at C-10. Jatrophane diterpenoids usually occur in the form of polyesters. Acetyl, benzoyl, nicotinoyl, propyl, isobutyl, 2methylbutyl, angeloyl, tigloyl, and cinnamoyl groups are the most frequent acyl residues. The number and positions of the double bonds and oxygen functions, as well as the esterification pattern can differ, which considerably increases the chemical variability of jatrophanes.

Hydroxy groups are most often found at C-3, C-5, C-7, C-9, and C-15, and in some cases at C-1, C-2, C-6, $\mathrm{C}-8, \mathrm{C}-11, \mathrm{C}-13, \mathrm{C}-14$, and $\mathrm{C}-17 .{ }^{105}$ The unusual presence of an $\mathrm{OH}$ group at C-4 was only reported in pubescenol (Figure 2, compound a). ${ }^{106}$ Keto groups are usually attached to C-9 and/or C-14. Jatrophanes containing a 11,12-epoxide ring were reported from E. lateriflora, ${ }^{76}$ E. welwitschii, ${ }^{107}$ E. salicifolia, ${ }^{25}$ E. kansui, ${ }^{108-110}$ and E. esula (Figure 2, b). ${ }^{17,111}$ Jatrophanes of E. mongolica, ${ }^{36}$ E. characias, ${ }^{75}$ and E. connata ${ }^{112}$ have a unique 5,6-epoxide structural part. Some of the jatrophane derivatives bear hemiketal moieties. Compounds with an ether bond between C-11 and C-14 are characteristic of E. kansui ${ }^{108-110}$ (Figure 2, c) and E. esula. ${ }^{17,32,111}$ Furthermore, some diterpenoids obtained from E. serrulata ${ }^{23,28}$ (Figure 2, d) and E. platyphyllos ${ }^{29}$ possess a 6,9-hemiketal, while jatrohemiketal from E. amygdaloides incorporates a tetrahydropyran ring formed between C-9 and C17 (Figure 2, e). ${ }^{113}$ The presence of an ether bridge connecting C-12 and C-15 is quite rare among the jatrophanes. ${ }^{102,107,114}$ Terracinolides identified from E. terracina (Figure 2, f), ${ }^{115,116}$ E. sororia, ${ }^{117}$ E. dendroides, ${ }^{80,83}$ and E. segetalis ${ }^{118}$ are based on a $C_{22}$ 17-ethyl bis-homojatrophane framework featured by a $\delta$-lactone. In the structural isomers isoterracinolides isolated from E. terracina, ${ }^{119}$ E. guyoniana, ${ }^{120}$ E. exigua, ${ }^{37}$ and E. sororia (Figure 2, g), ${ }^{117,121}$ and in salicinolide isolated from E. salicifolia, ${ }^{26}$ the 8 -membered lactone rings are closed between the two-carbon fragment attached to $\mathrm{C}-17$ and the oxygen function at $\mathrm{C}-3$ or $\mathrm{C}-9$, respectively.

The great majority of jatrophanes contain a 6(17)-exomethylene group. Jatrophane diterpenoids can be categorized as exo- and endo-conformers based on the spatial orientation of 6(17)-exomethylene 
with respect to the mean plane of the macrocycle. ${ }^{83}$ In the more common exo-form the exomethylene points outward, thus it is parallel with the mean plane of the twelve-membered ring, while in the endotype conformation it is perpendicular to the plane. The ${ }^{3} \mathrm{~J}_{\mathrm{H} 4-5}$ coupling constant is either small $(0-3 \mathrm{~Hz}$ - exo) or large (9-11 Hz - endo) depending on which conformer the particular diterpenoid adopts. ${ }^{83,122}$ In an exo-conformer the adjacent $\mathrm{H}-4$ and $\mathrm{H}-5$ protons are almost orthogonal to each other, while in an endo-conformer they are antiperiplanar. Besides the common endocyclic $\Delta^{(11,12)}$ double bond, olefin groups are sometimes formed between $\mathrm{C}-4 / \mathrm{C}-5,{ }^{24} \mathrm{C}-5 / \mathrm{C}-6,{ }^{24} \mathrm{C}-7 / \mathrm{C}-8,{ }^{19}$ and $\mathrm{C}-12 / \mathrm{C}-13 .{ }^{123}$ Jatrophanes of Pedilanthus tithymaloides contain rare $\Delta^{(3,4)}$ and/or $\Delta^{(6,7)}$ double bonds (Figure 2, h). ${ }^{124}$

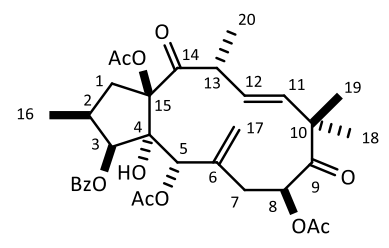

a

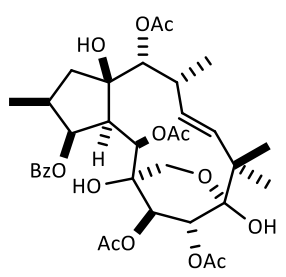

e

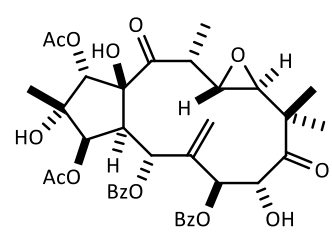

b

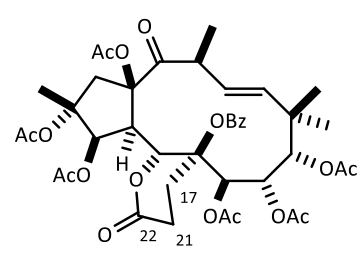

f
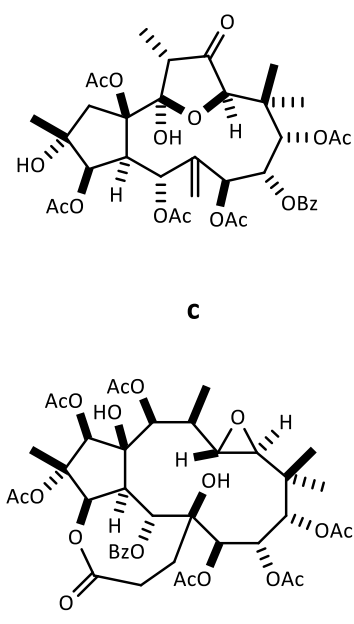

g

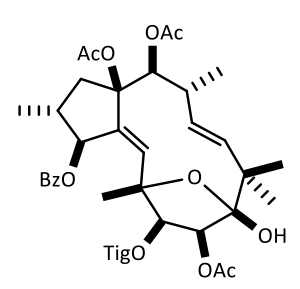

d

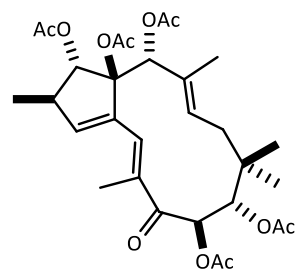

h

Figure 2. Selected diterpenoids illustrating the chemical diversity of jatrophanes.

Several modified jatrophane derivatives are reported in the literature. Heliojatrones $\mathrm{A}-\mathrm{C}$ with an unprecedented trans-bicyclo[8.3.0]tridecane scaffold were isolated from E. helioscopia (Figure 3, i). ${ }^{125,126}$ Abeo-jatrophanes constitute an extraordinary group of rearranged diterpenoids. It is postulated that $1(15 \rightarrow 14)$ abeo-jatrophanes might arise from a pinacol-type rearrangement. ${ }^{105}$ Although this kind of reaction could possibly occur in all of the 14-keto-15-hydroxy jatrophanes, to the best of our knowledge, until now such compounds have only been detected in E. dendroides (Figure 3, j) and E. terracina ${ }^{80,127}$ Euphosalicin isolated from E. salicifolia is the only known $9(10 \rightarrow 18)$ abeojatrophane. ${ }^{25}$ Heliosterpenoids $A$ and $B$ obtained from $E$. helioscopia, and gaditanone derived from $E$. gaditana (Figure 3, k), possessing a novel 5/6/4/6-fused tetracyclic ring system, are presumably formed from a general jatrophane skeleton via intramolecular [2+2] cycloadditions between the positions 5 and 12, and 6 and $11 .{ }^{128,129}$ Euphowelwitschines $A$ and $B$ are interesting 12,17cyclojatrophanes having an additional tetrahydrofuran ring. ${ }^{107}$ Salicifoline isolated from E. salicifolia is another 12-17-cyclo-derivative with an epoxy function. ${ }^{26}$ Secoheliosphanes $A$ and $B$ are based on an unusual 7,8-seco jatrophane skeleton (Figure 3, I). ${ }^{130}$ Moreover, in a very recent study E. helioscopia 
has been reported to contain two novel diterpenoids based on a 4-(5,5-dimethylheptan-2-yl)-2,7dimethylbicyclo[4.3.0]nonane framework (Figure 3, m). ${ }^{131}$ Guided by the presence of the 3,3dimethylhept-4-en-2-one side chain, which is a common structural fragment of the 12-membered macrocycle, the authors concluded that these compounds might be converted from the co-occurring jatrophanes euphoscopin A and epieuphoscopin A.

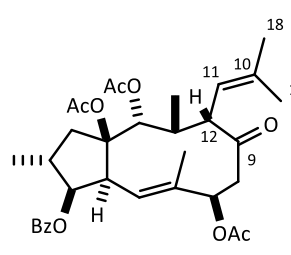

i

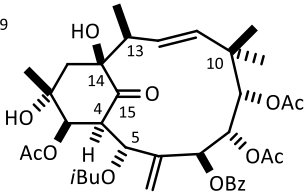

j

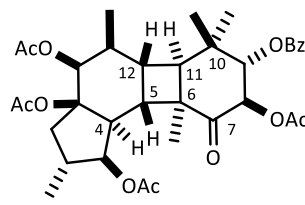

k

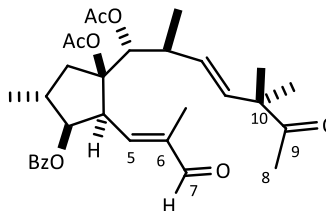

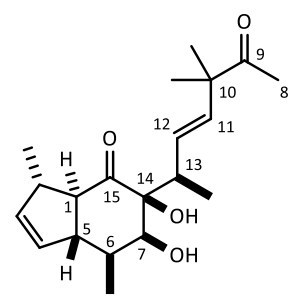

m

Figure 3. Examples of rearranged jatrophane derivatives.

Jatrophane diterpenoids do not form a stereochemically homogeneous series, because the configurations of asymmetric carbons are variable. Findings from current studies investigating the absolute configuration of jatrophanes by $\mathrm{X}$-ray diffraction or circular dichroism are in line with previous reports: $\mathrm{H}-4$ is $\alpha$, and $15-\mathrm{OH}$ or 15 -acyl group is $\beta$ in all of the natural jatrophanes. ${ }^{83,117,129,132-134}$

The fascinating structures of jatrophanes give rise to complex interactions with living organisms. Jatrophanes might be best known for their MDR modulator activity. This noteworthy feature of jatrophanes was first reported by Hohmann and co-workers, ${ }^{24}$ followed by a number of published articles in the past 17 years. Recent findings also support the promising MDR modulator role of jatrophanes. Their MDR reversing effects on cancer cell lines of different origin are often as good as that of the positive controls verapamil ${ }^{79,85,134}$ or cyclosporin, ${ }^{125,132}$ while even compounds exerting many-times stronger activities have also been described. ${ }^{117}$ The fruits of $E$. sororia afforded a jatrophane which significantly enhanced the effect of vinorelbine against KBV200 cell xenografts in nude mice. ${ }^{135}$ Macrocyclic diterpenoids of Euphorbia species are proven to be potent inhibitors of MDR proteins of Candida albicans; substantial decrease in yeast growth was observed at submicromolar concentrations of these terpenoids in the presence of fluconazole. ${ }^{84,136}$ Besides inhibiting Pglycoprotein-mediated drug resistance, some jatrophanes also synergize with paclitaxel, ${ }^{137}$ doxorubicin, ${ }^{138}$ and epirubicin. ${ }^{139}$ Further jatrophane diterpenoids exerting strong proapoptotic effects on human gastric and pancreatic tumor cells, as well as on ovarian cancer cell lines were isolated from E. welwitschii, ${ }^{138}$ E. osyridea, ${ }^{140}$ and E. cyparissias, ${ }^{141}$ respectively. Jatrophanes from E. dendroides are reported to exert anti-angiogenic activity by decreasing the secretion of vascular endothelial growth factor, ${ }^{142}$ while macrocyclic diterpenoids yielded from the Sardinian endemic species E. semiperfoliata 
were found to interact with tubulin polymerization. ${ }^{143}$ Pešić et al. have concluded that the synergism between paclitaxel and jatrophanes is partly due to their mutual effects on microtubule assembly that leads to cell cycle arrest at the G2/M phase. ${ }^{142}$

However, the scientific merit of jatrophane diterpenoids is not limited to their anticancer properties. The jatrophane esters isolated by bioassay-guided purification of the EtOAc extract of E. amygdaloides ssp. semiperfoliata inhibit the replication of HIV-1, HIV-2, and chikungunya viruses. ${ }^{144}$ Bedoya et al. reported that a jatrophane of $E$. hyberna, assigned as SJ23B, prevents the viral infections of human primary $\mathrm{T}$ cells at nanomolar concentrations by inducing the internalization of HIV-1 receptors, and suggested that the activation of classical PKCs might explain the mitigation of viral reservoirs. ${ }^{145} \mathrm{E}$. helioscopia furnished a jatrophane polyester that exerts significant antimicrobial activity against the oral pathogens Streptococcus mutans and Actinomyces viscosus. ${ }^{146}$ The polyacylated diterpenoids of $P$. tithymaloides show pronounced antiplasmodial activity, and one of the tested compounds was found to be moderately effective against Mycobacterium tuberculosis. ${ }^{147}$ Jatrophone and some of its semisynthetic derivatives, together with euphorbesulin $\mathrm{G}$ from $E$. esula display notable activity against Plasmodium falciparum strains. ${ }^{148,149}$ Jatrophanes of E. kansui, ${ }^{150}$ E. helioscopia, ${ }^{151,152}$ and E. peplus ${ }^{153}$ are potent inhibitors of the lipopolysaccharide-induced production of NO, which is a key signalling molecule in the pathogenesis of inflammation. In other experiments jatrophanes exerted lipid lowering, ${ }^{133}$ neuroprotective, ${ }^{109,132,152}$ and vasodepressor effects. ${ }^{154}$

\subsubsection{Segetane diterpenoids}

Segetanes, a unique class of Euphorbia diterpenoids are characterized by a modified jatrophane core incorporating a bicyclo[4.3.1]decane ring system. Prior to our research work, only 12 segetanes had been identified from E. segetalis (Figure 4, n), ${ }^{118}$ E. paralias, ${ }^{155-158}$ E. portlandica, ${ }^{159}$ and E. peplus. ${ }^{153}$ Segetanes might be synthetized from jatrophane precursors via two-step transannular cyclization processes. Jakupovic et al. proposed that the first step could be an intramolecular $\mathrm{C}-\mathrm{C}$ bond formation between $\mathrm{C}-8$ and $\mathrm{C}-12$, which would yield a tricyclic intermedier called presegetane. Later on this hypothesis was reinforced by the presence of presegetane diterpenoids in E. esula and E. paralias (Figure 4, 0). ${ }^{149,158} \mathrm{~A}$ related isomer, 15-epi-presegetane with an inner ketal structural part was obtained from E. segetalis (Figure 4, p). ${ }^{118}$ The second step of biosynthesis is most likely a subsequent ring closure occurring between C-13 and C-17. An alternative approach was reported by Wang et al., who achieved the single-step Diels-Alder synthesis of a segetane diterpenoid from a jatrophane precursor. ${ }^{153}$ Due to the limited number of studies, knowledge on the pharmacological properties of segetane diterpenoids is scarce. Compounds of this group are reported to possess in vitro antiinflammatory and MDR modulating activities. ${ }^{153,159}$ 


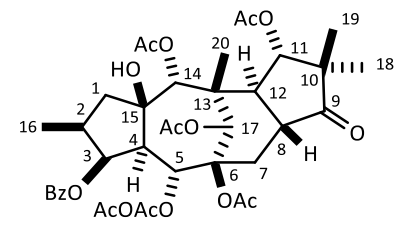

n

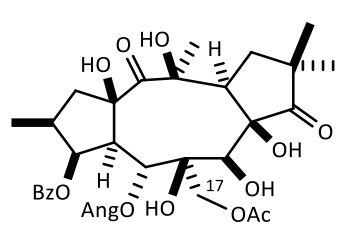

o

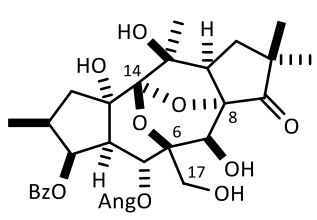

$\mathbf{p}$

Figure 4. Some of the segetanes and segetane-related diterpenoids.

\subsubsection{Ingenane diterpenoids}

The intriguing group of ingenane diterpenoids are based on a bicyclo[4.4.1]undecane-11-one core with a highly strained inside-outside trans-intrabridgehead stereochemistry. ${ }^{160}$ This structural feature is very rare in natural compounds: apart from the ingenanes, seco-trinervitane diterpenoids isolated from nasute termite species are the only examples displaying in/out stereochemistry. ${ }^{161}$ The chemical structures of ingenanes are far less diverse compared to jatrophanes. The skeleton of ingenane diterpenes isolated to date always comprises a $\Delta^{(1,2)}$ and a $\Delta^{(6,7)}$ endocyclic double bond. The cyclopentane and cycloheptane rings in the 5/7/7/3-tetracyclic ring system are trans-fused. ${ }^{162} \mathrm{~A}$ $\beta$-hydroxy group is linked to $C-4$, and other oxygen functionalities are usually found on C-3, C-5, C-13, C-17, and C-20. The hydroxy moieties are esterified with acetyl, angeloyl, dimethylbutanoyl, and benzoyl groups, or long-chain (octanoyl, decanoyl, decadienoyl, tetradecadienoyl, dodecanoyl, myristoyl, palmitoyl etc.) fatty acids. Ingenanes from E. cornigera contain $\mathrm{N}$-(2aminobenzoyl)anthraniloyl moieties (Figure 5, q), ${ }^{66}$ while E. milii and E. leuconeura afforded ingenanes with unique tri-anthraniloyl peptides attached to the diterpenoid core at C-3 (Figure 5, r). ${ }^{70,163}$ An ingenane, euphorkanlide $A$ isolated from $E$. kansuensis contains a quite strange $C_{24}$ appendige, which forms a hexahydroisobenzofuran-fused 19-membered macrocyclic bis-lactone ring system (Figure 5, s). ${ }^{164}$

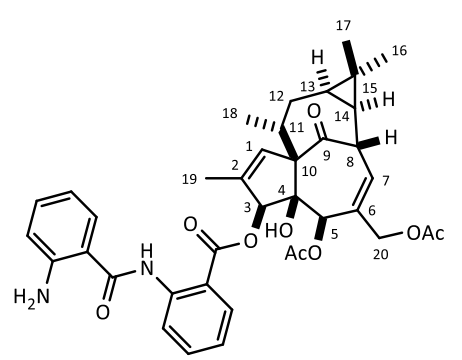

$\mathbf{q}$

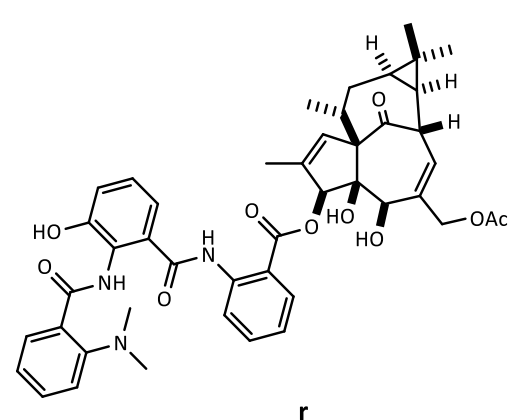

$\mathbf{r}$

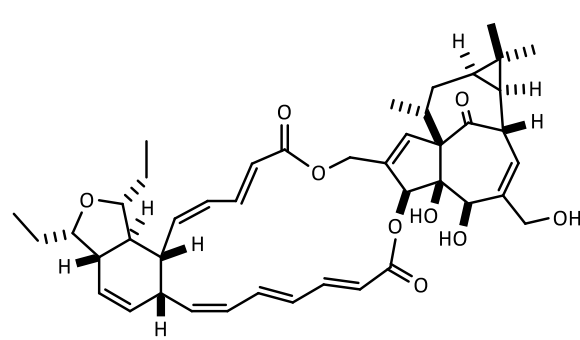

$\mathbf{S}$

Figure 5. Ingenane diterpenoids with unique side chains.

Ingenol mebutate is definitely the most prominent member of ingenanes. Ingenol mebutate, or ingenol 3-angelate is the active principle of the commercially available Picato ${ }^{\circledR}$ gel, approved by the 
U.S. Food and Drug Administration (FDA) in 2012 and the European Medicines Agency (EMA) in 2013 for the topical treatment of actinic keratosis, a common premalignant skin-condition. ${ }^{89}$ The presence of ingenol mebutate in E. peplus was first reported by Hohmann et al. during a screen of Hungarian Euphorbia species. ${ }^{22}$ It had previously been isolated from other Euphorbias (E. antiquorum, E. helioscopia, and E. paralias), too. Due to the unusual structural elements of the parent compound ingenol, including the congested $3 \beta, 4 \beta, 5 \beta$-triol part, an adjoining quaternary stereocenter and a dimethylcyclopropane moiety, the synthesis of ingenol mebutate is extremely challenging. ${ }^{165}$ Currently the general source of ingenol mebutate is E. peplus. ${ }^{166}$

The C-3 monoesters of ingenol, together with structurally related phorbols, are potent tumor promoter and pro-inflammatory agents. Their carcinogenic and irritant properties have been shown to correlate with the length of the aliphatic chain: compounds with longer ester groups were found to be more toxic. ${ }^{167}$ Ingenol mebutate bearing a smaller C-3 angeloyl group has anticancer activity, mediated by a dual mechanism. First, it induces the translocation of pro-apoptotic intracellular PKC into cytoplasmic and nuclear membranes, which ultimately leads to rapid mitochondrial disruption and the consequent apoptosis of dysplastic keratinocytes. ${ }^{168}$ In addition to its necrotic effect, ingenol mebutate promotes the infiltration of neutrophils into the affected areas, which then eliminate malfunctioning epidermal cells by antibody-dependent cellular cytotoxicity. Ingenol 3,20-dibenzoate is a noteworthy compound because, in sharp contrast to other 3-acyl esters of ingenol, it is able to selectively activate the novel forms of PKCs. The activation of this class of enzymes has been associated with in vivo thrombopoietic effects, therefore the dibenzoate derivative of ingenol may represent a novel strategy for alleviating bone marrow damage caused by toxic anticancer agents. ${ }^{169}$ Recent studies have also reported antinematodal, ${ }^{170}$ anti-HIV, ${ }^{171,172}$ cytotoxic, ${ }^{173}$ and interferon gamma (INFү) production modulating activities ${ }^{174}$ of ingenane diterpenoids.

\subsection{Chemistry and folk medicinal use of the investigated Euphorbia species}

The chemical constituents of E. dulcis have only been investigated by Pohl et al., who isolated quercetin-3-O- $\beta$-glucoside, quercetin-3-O- $\beta$-galactoside and quercetin-3-O- $\beta$-galactoside-6"-gallate from the plant. ${ }^{175}$ Phytochemical screening revealed the presence of sterols, carotenoids, tannins, flavone glycosides, and anthocyanosides in different parts of E. guyoniana. ${ }^{176}$ Boudiar et al. reported the isolation of a new alkaloid, 1,5-diphenyl-3-styryl-2-pyrazolin, and six known flavonoids (kaempferol, quercetin, and their glycosides) from the acetone extract of aerial parts of E. guyoniana ${ }^{177}$ Diterpene content of E. guyoniana of Algerian origin was also examined earlier, and ent-abietane, atisane, jatrophane and tigliane type diterpenes were isolated from the roots, ${ }^{178,179,180}$ 
as well as the jatrophanes guyonianin A-F from the aerial parts. ${ }^{120,181,182}$ To the best of our knowledge, no data had been previously published on the chemical compositions of E. taurinensis and E. davidii. In the Algerian and Tunisian folk medicines preparations of E. guyoniana have long been used for the treatment of pain, cough, diarrhoea, wounds, warts, skin diseases, stings of venomous scorpions, and snakebites. ${ }^{120,183}$ E. dulcis, E. taurinensis, and E. davidii are not used in traditional medicine.

\section{Aims of the study}

As a part of ongoing research, the goals of my work were the isolation and structure determination of new diterpenoids, followed by the investigation of their bioactivity, executed in collaboration with cooperative partners. In order to meet these objectives, the main tasks were as follows:

- Screening of E. dulcis, E. taurinensis, and E. davidii for their diterpenoid contents (diterpenoids have previously been described from E. guyoniana, thus screening of this Saharan species was unnecessary).

- Extraction of the plant materials of E. dulcis, E. taurinensis, E. guyoniana, and E. davidii.

- Isolation and purification of the diterpenoids by various chromatographic methods (polyamide OCC, VLC, PLC, and HPLC).

- Structure elucidation of the diterpenoids by means of advanced spectroscopic techniques (1D- and 2D NMR, HRMS, single-crystal X-ray diffraction).

- Assessment of the chemotaxonomic importance of the isolated compounds.

- Evaluation of the pharmacological properties of diterpenoids (GIRK- and hERG channel inhibitory activity, MDR modulation, cytotoxicity).

\section{Materials and methods}

\subsection{Plant materials}

E. dulcis: Whole plants $(3.8 \mathrm{~kg}$ ) were collected in the flowering period at Homoródalmás, Romania, in July 2014. The plant material was identified by Dr. Gusztáv Jakab (Institute of Environmental Sciences, Szent István University, Szarvas, Hungary). The fresh plant material was frozen and stored at $-20{ }^{\circ} \mathrm{C}$ until extraction.

E. taurinensis: Whole plants (1 kg) were collected in May 2014, in Budapest, Hungary (at latitude $47^{\circ} 27^{\prime} 35^{\prime \prime} \mathrm{N}$ and longitude $19^{\circ} 3^{\prime} 34^{\prime \prime} \mathrm{E}$ ) and identified by Dr. Zoltán Barina (Department of Botany, Hungarian Natural History Museum, Budapest, Hungary). The phytochemical analysis of E. taurinensis was immediately started after harvesting the plants.

E. guyoniana: Aerial parts were gathered in 2013 in southern Tunisia, specifically from the droughty natural region called Grand Erg Oriental. The plant material was identified by Dr. Mohamed Chaieb 
(Department of Biology and Ecology of Arid Land, University of Sfax, Sfax, Tunisia). Aerial parts were dried at room temperature ( $45 \mathrm{~g})$.

E. davidii: Whole plants (15 kg) were collected near Igar, Hungary in September 2011, and identified by Dr. Gyula Pinke (Department of Botany, University of West Hungary, Mosonmagyaróvár, Hungary). The fresh plant material was stored at $-20^{\circ} \mathrm{C}$ until further preparation.

Voucher specimens of E. dulcis, E. taurinensis, and E. davidii (numbers: 838, 879, and 836, respectively) have been deposited in the Herbarium of the Department of Pharmacognosy, University of Szeged, Szeged, Hungary. A voucher specimen of E. guyoniana has been retained under the name of EUPH 07 in the Herbarium of University of Sfax, Sfax, Tunisia.

\subsection{Screening of plant materials for diterpenoid content}

The plant samples of E. dulcis, E. taurinensis, and E. davidii (each $50 \mathrm{~g}$ ) were crushed and thoroughly extracted with $\mathrm{MeOH}(500 \mathrm{~mL})$ in an ultrasonic bath $(45 \mathrm{~min})$ at room temperature. The concentrated extracts were diluted with $\mathrm{H}_{2} \mathrm{O}(30 \mathrm{~mL})$, and then subjected to solvent-solvent partitioning with $\mathrm{CHCl}_{3}$ $\left(3 \times 50 \mathrm{~mL}\right.$ ). The $\mathrm{CHCl}_{3}$-soluble phases were separated by polyamide OCC using gradient solvent systems of $\mathrm{MeOH}-\mathrm{H}_{2} \mathrm{O}[3: 2,4: 1$, and pure $\mathrm{MeOH}$ (each $150 \mathrm{~mL}$ ); mobile phases are given in terms of volume ratio, v/v]. The collected fractions were developed in cyclohexane-EtOAc-EtOH (30:10:1) and were visualized by $c c . \mathrm{H}_{2} \mathrm{SO}_{4}$ followed by heating at $110{ }^{\circ} \mathrm{C}$ for 2 minutes.

\subsection{Extraction and isolation, and preparation of plant extracts}

\subsubsection{Extraction}

The frozen plant material of E. dulcis and the fresh parts of E. taurinensis were crushed with a Waring CB-6 commercial blender (model 33BL13) and exhaustively percolated with $\mathrm{MeOH}$ (30 L and $10 \mathrm{~L}$ ) at room temperature. The extracts were concentrated in vacuo by a Büchi Rotavapor R-200 $\left(40{ }^{\circ} \mathrm{C}, 337\right.$ mbar) and resuspended in $\mathrm{H}_{2} \mathrm{O}(500 \mathrm{~mL}$ and $300 \mathrm{~mL})$ prior to liquid-liquid partitioning with $\mathrm{CHCl}_{3}(5 \mathrm{x}$ $500 \mathrm{~mL}$ and $6 \times 300 \mathrm{~mL})$.

The air-dried herbal sample of E. guyoniana was powdered with a Bosch MKM 6000 grinder. The raw material was extracted with $\mathrm{CHCl}_{3}(3 \times 300 \mathrm{~mL})$ in an ultrasonic bath $(3 \times 15 \mathrm{~min})$ at room temperature. The extracts were concentrated in vacuo $\left(30^{\circ} \mathrm{C}, 474 \mathrm{mbar}\right)$.

The frozen plant parts of $E$. davidii were crushed with a Waring CB-6 blender and extracted with $\mathrm{MeOH}$ (15 L) at room temperature. The solvent was evaporated in vacuo (40 ${ }^{\circ} \mathrm{C}, 337$ mbar). After concentration, the crude residue was diluted with water $(1000 \mathrm{~mL})$, and then subjected to repeated solvent-solvent extraction using $\mathrm{CHCl}_{3}(5 \times 1500 \mathrm{~mL})$ and $\mathrm{EtOAc}(5 \times 1000 \mathrm{~mL})$. 


\subsubsection{Purification and isolation of compounds}

Open-column chromatography: OCC was performed on polyamide (MP Polyamide, 50-160 $\mu \mathrm{m}$, MP Biomedicals) for column chromatography $(220 \mathrm{~g}, 70 \mathrm{~g}$, and $6 \mathrm{~g}$ for the plant extracts of E. dulcis, E. taurinensis and E. guyoniana, respectively). The crude extracts were dissolved in $\mathrm{CHCl}_{3}$ and adsorbed onto polyamide. The organic solvent was completely eliminated in a ventilated hood, and the obtained powdery materials were loaded into chromatographic columns. The plant extracts were eluted with mixtures of $\mathrm{MeOH}-\mathrm{H}_{2} \mathrm{O}$ [3:2 and 4:1 (E. dulcis: 4500 and $2200 \mathrm{~mL}$, E. taurinensis: $400 \mathrm{~mL}$ each, E. guyoniana: $50 \mathrm{~mL}$ each)].

Vacuum-liquid chromatography: For VLC, silica gel (Kieselgel $\mathrm{GF}_{254}, 15 \mu \mathrm{m}$, Merck) and RP silica gel (LiChroprep RP-18, 40-63 $\mu \mathrm{m}$, Merck) were used. The extracts were dissolved in $\mathrm{CHCl}_{3}$ and adsorbed onto one-tenth of the silica, then the organic solvent was completely removed in a ventilated hood. The dry-packed columns were prepared by filling the remaining silica gel into glass filter funnels containing fritted discs (G3) at their bottom. The powders of extracts were placed at the top of the stationary phase. The VLC columns were developed under gentle vacuum provided by a semiautomatic Büchi V-800 Vacuum Controller. The collected fractions were combined in accordance with their chemical compositions monitored by TLC.

Fractionation by VLC on normal phase silica gel

Column 1 eluent: cyclohexane-EtOAc-EtOH (70:10:0, 60:10:0, 50:10:0, 50:10:1, 40:10:1, 30:10:1, 20:10:1; $200 \mathrm{~mL}$ each); volumes of collected fractions: $25 \mathrm{~mL}$; sorbent: $75 \mathrm{~g}$

Column 2 eluent: toluene- $\mathrm{CHCl}_{3}-\mathrm{Me}_{2} \mathrm{CO}$ (70:10:1, $50 \mathrm{~mL} ; 60: 10: 1,50 \mathrm{~mL}$; 50:10:1, 50 $\mathrm{mL}$; 40:10:1, $50 \mathrm{~mL}$; 30:10:1, $100 \mathrm{~mL}$; 20:10:1, $100 \mathrm{~mL}$; 10:10:1, $50 \mathrm{~mL}$; volumes of collected fractions: $15 \mathrm{~mL}$; sorbent: $25 \mathrm{~g}$

Column 3 eluent: cyclohexane-EtOAc-EtOH (80:10:0, 60:10:0, 40:10:0, 30:10:0, 20:10:0, 20:10:2; $120 \mathrm{~mL}$ each); volumes of collected fractions: $10 \mathrm{~mL}$; sorbent: $50 \mathrm{~g}$

Column 4 eluent: cyclohexane-EtOAc-EtOH (60:10:0, 40:10:0, 30:10:0, 30:10:1, 30:20:1, 30:20:2; $200 \mathrm{~mL}$ each); volumes of collected fractions: $15 \mathrm{~mL}$; sorbent: $50 \mathrm{~g}$

Column 5 eluent: cyclohexane- $\mathrm{CHCl}_{3}-\mathrm{Me}_{2} \mathrm{CO}$ (15:10:0.5, 10:20:2, 10:20:3, 5:20:5; $70 \mathrm{ml}$ each); volumes of collected fractions: $5 \mathrm{~mL}$; sorbent: $25 \mathrm{~g}$

Column 6 eluent: cyclohexane-EtOAc-EtOH (60:10:0, 30:10:0, 30:10:1, 30:20:1; $120 \mathrm{~mL}$ each); volumes of collected fractions: $10 \mathrm{~mL}$; sorbent: $40 \mathrm{~g}$

Column 7 eluent: EtOAc-EtOH- $\mathrm{H}_{2} \mathrm{O}$ (32:2:0, 32:2:1, 32:2:1.5, 32:4:1.5, 32:4:2, 32:8:4, 32:16:8, 32:32:16; $1500 \mathrm{~mL}$ each); volumes of collected fractions: $100 \mathrm{~mL}$; sorbent: $330 \mathrm{~g}$ 
Fractionation by VLC on reversed-phase silica gel

Column 8 eluent: $\mathrm{MeOH}-\mathrm{H}_{2} \mathrm{O}$ (6:4, 7:3, 8:2, 10:2, 10:1; $100 \mathrm{~mL}$ each); volumes of collected fractions: $10 \mathrm{~mL}$; sorbent: $23 \mathrm{~g}$

Column 9 eluent: $\mathrm{MeOH}-\mathrm{H}_{2} \mathrm{O}$ (5:5, 6:4, 7:3, 8:2, 9:1; $200 \mathrm{~mL}$ each); volumes of collected fractions: $15 \mathrm{~mL}$; sorbent: $54 \mathrm{~g}$

Preparative layer chromatography: PLC was carried out on $10 \times 20 \mathrm{~cm}$ plates coated with NP and RP silica gel (TLC Silica gel $60 \mathrm{~F}_{254}$, and TLC Silica gel 60 RP-18 $\mathrm{F}_{2545}$, Merck). Separation was accomplished by developing the plates in glass chambers previously saturated with mobile phase vapor for 10 minutes. The chromatograms were visualized by:

- UV-light: the TLC plates were exposed to UV light at $254 \mathrm{~nm}$

- $c c . \mathrm{H}_{2} \mathrm{SO}_{4}$ : after spraying $c c . \mathrm{H}_{2} \mathrm{SO}_{4}$ at the right borders, $\mathrm{TLC}$ plates were heated at $110{ }^{\circ} \mathrm{C}$ for 2 minutes

The purified compounds were eluted from the scraped adsorbent with $\mathrm{CHCl}_{3}$.

$>$ Purification by PLC on normal phase silica gel

Mobile phase 1: toluene- $\mathrm{Me}_{2} \mathrm{CO}$ (10:2); mobile phase 2: toluene- $\mathrm{Me}_{2} \mathrm{CO}$ (8:2); mobile phase 3: cyclohexane- $\mathrm{CHCl}_{3}-\mathrm{MeOH}$ (15:10:1); mobile phase 4: cyclohexane-EtOAc-EtOH (25:15:1); mobile phase 5: EtOAc- $\mathrm{HCOOH}-\mathrm{H}_{2} \mathrm{O}(85: 10: 5)$

$>$ Purification by PLC on reversed-phase silica gel

Mobile phase 6: $\mathrm{MeOH}-\mathrm{H}_{2} \mathrm{O}$ (11:2); mobile phase 7: $\mathrm{MeCN}-\mathrm{H}_{2} \mathrm{O}$ (11:1); mobile phase 8: $\mathrm{MeOH}-\mathrm{H}_{2} \mathrm{O}(10: 1)$; mobile phase 9: $\mathrm{MeCN}-\mathrm{H}_{2} \mathrm{O}(3: 1)$

HPLC: separations by HPLC were performed on pre-packed Hibar RT LiChrospher Si 100 and LiChrospher RP-18 columns ( $250 \times 4$ mm, $5 \mu \mathrm{m}$, Merck), using a Waters Millipore instrument consisted of a Controller 600, a Pump 600, a Photodiode Array Detector 2998, an In-Line Degasser AF, and an Injector Rheodyne 7725i. Chromatographic separations were monitored at 254 and $366 \mathrm{~nm}$. The samples were filtered through PTFE-L syringe filters (pore size $0.45 \mu \mathrm{m}$, FilterBio) before injection. 
Purification by NP-HPLC

Method 1

eluent: cyclohexane-EtOAc-EtOH (90:15:0.2); flow rate: $0.6 \mathrm{~mL} / \mathrm{min}$

Method 2

eluent: cyclohexane-EtOAc-EtOH (25:15:1); flow rate: $1.5 \mathrm{~mL} / \mathrm{min}$

Method 3

eluent: cyclohexane-EtOAc-EtOH (50:10:1); flow rate: $1.5 \mathrm{~mL} / \mathrm{min}$

Method 4

eluent: cyclohexane-EtOAc-EtOH (30:10:1); flow rate: $1.5 \mathrm{~mL} / \mathrm{min}$

$>$ Purification by RP-HPLC

Method $5 \quad$ eluent: $\mathrm{MeCN}-\mathrm{H}_{2} \mathrm{O}$ (7:3); flow rate: $1.5 \mathrm{~mL} / \mathrm{min}$

Method 6 eluent: $\mathrm{MeCN}-\mathrm{H}_{2} \mathrm{O}$ (6:4); flow rate: $1.5 \mathrm{~mL} / \mathrm{min}$

Method $7 \quad$ eluent: $\mathrm{MeCN}-\mathrm{H}_{2} \mathrm{O}$ (1:1); flow rate: $1.5 \mathrm{~mL} / \mathrm{min}$

Method $8 \quad$ eluent: $\mathrm{MeOH}-\mathrm{H}_{2} \mathrm{O}-\mathrm{THF}$ (10:3:7); flow rate: $0.5 \mathrm{~mL} / \mathrm{min}$

Method $9 \quad$ eluent: $\mathrm{MeCN}-\mathrm{H}_{2} \mathrm{O}-\mathrm{HCOOH}$ (30:70:1); flow rate: $0.5 \mathrm{~mL} / \mathrm{min}$

The collected fractions were concentrated in vacuo under $40{ }^{\circ} \mathrm{C}$. The diterpenoids were kept in dark vials in a refrigerator. The purity of the obtained compounds was checked by TLC and HPLC methods prior to submitting them to pharmacological investigations.

\subsubsection{Preparation of plant extracts for pharmacological screening}

For pharmacological investigations, $50 \mathrm{~g}$ fresh plant material of $E$. davidii was extracted with $\mathrm{MeOH}$ $(500 \mathrm{~mL})$ in an ultrasonic bath. After filtration, the extract was evaporated to dryness under reduced pressure. The obtained viscous residue was dissolved in $50 \%$ aqueous $\mathrm{MeOH}(50 \mathrm{~mL})$ and was then subjected to solvent-solvent partition with $n$-hexane, $\mathrm{CHCl}_{3}$, and EtOAc (each $3 \times 50 \mathrm{~mL}$ ). In the next step, the dried plant material was subsequently extracted with boiling $\mathrm{H}_{2} \mathrm{O}$ (400 mL, $15 \mathrm{~min}$ ). The organic phases were concentrated under vacuum, while the aqueous portions were freeze-dried.

\subsection{Characterization and structure determination of the isolated compounds}

Mass spectroscopy: High-resolution MS data were recorded on a Thermo Q Exactive Plus Orbitrap mass spectrometer equipped with an ESI electrospray source and coupled with an Agilent 1100 HPLC system. The samples were measured with flow injection analysis method. The mass spectrometer was working in positive mode, and the scan mass range was set to $\mathrm{m} / \mathrm{z} 150-2000$ at a resolution of 140000 . The data were acquired and processed with Thermo Xcalibur 4.0 software.

Nuclear magnetic resonance spectroscopy: NMR spectra were recorded in $\mathrm{CDCl}_{3}, \mathrm{CD}_{3} \mathrm{OD}$, and $\mathrm{C}_{5} \mathrm{D}_{5} \mathrm{~N}$ on a Bruker Avance DRX 500 spectrometer at $500 \mathrm{MHz}\left({ }^{1} \mathrm{H}\right)$ and $125 \mathrm{MHz}\left({ }^{13} \mathrm{C}\right)$. The signals of the residual solvents $\left(\delta_{H} 7.26,3.31\right.$, and $8.74 \mathrm{ppm} ; \delta_{C} 77.16,49.00$, and $150.35 \mathrm{ppm}$, respectively) were taken as reference points. Chemical shifts are expressed in parts per million (ppm) and coupling constant $(J)$ 
values in $\mathrm{Hz}$. The 2D data were acquired and processed with MestReNova v6.0.2-5475 and TopSpin $3.5 p l 7$ softwares.

Ultraviolet spectroscopy: UV spectra were measured in MeOH by a Shimadzu UV-2101 spectrometer. $X$-ray crystallographic study: Intensity data of 1 was collected at synchrotron SOLEIL at the PROXIMA 1 beamline (macromolecular crystallography beamline, $\lambda=0.79990 \AA$, beam size $\mathrm{HxV}=40 \times 30 \mu \mathrm{m}^{2}$ ) at $100(2) \mathrm{K}$ in the range of $1.682^{\circ} \leq \theta \leq 31.198^{\circ}$. The structure was solved by direct methods and refined by full-matrix least squares.

Melting point: Melting point of compound 1 was determined by a Linkam hot stage microscope (temperature range of $-180-400^{\circ} \mathrm{C}$ ). Melting points of the rest of the diterpenoids are uncorrected. Optical rotation: Optical rotations were measured in $\mathrm{CHCl}_{3}$ by using a Perkin Elmer 341 polarimeter.

\section{Results}

\subsection{Screening of E. dulcis, E. taurinenis, and E. davidii for diterpenoid contents}

The extractions and preparations of the samples were carried out as described in section 3.2. Concerning the screening results of E. dulcis and E. taurinensis, TLC chromatograms of fractions eluted with $60 \%$ aqueous $\mathrm{MeOH}$ exhibited dense brown and black spots attributable to diterpenoid esters $\left(R_{f}\right.$ values: $0.15-0.70)$. TLC monitoring of fractions obtained with $\mathrm{MeOH}-\mathrm{H}_{2} \mathrm{O}(4: 1)$ revealed purple spots on the plates with higher $R_{f}$ values $(0.75-0.95)$, which indicated the predominant presence of triterpenes and fats. The aforementioned observations suggested that the apolar extracts of $E$. dulcis and E. taurinensis contain a series of different diterpenoids. In case of E. davidii, the lack of characteristic brown and black spots of diterpenoids implied that these secondary metabolites are absent or present in very low concentrations in the plant.

\subsection{Isolation procedures}

\subsubsection{Isolation of diterpenoids from $E$. dulcis}

Since diterpenoids have been reported from different organs of Euphorbia species, the whole plants of $E$. dulcis were collected. Post-mortem enzymatic activity was stopped by freezing the harvested fresh plants. The frozen plant material was crushed and exhaustively percolated with $\mathrm{MeOH}$ at room temperature. The crude extract was concentrated under reduced pressure, resuspended in $\mathrm{H}_{2} \mathrm{O}$, and subjected to solvent-solvent partitioning with $\mathrm{CHCl}_{3}$. Upon evaporation of the solvent, the organic phase yielded a dark green oily residue ( $33.6 \mathrm{~g}$ ), which was chromatographed on a polyamide column with mixtures of $\mathrm{MeOH}-\mathrm{H}_{2} \mathrm{O}$ (Figure 6). The TLC analysis showed that the diterpenoids accumulated in the fraction eluted with $\mathrm{MeOH}-\mathrm{H}_{2} \mathrm{O}(3: 2)$. The $\mathrm{MeOH}-\mathrm{H}_{2} \mathrm{O}(4: 1)$ eluate contained mainly chlorophyll, triterpenes, and fats, and was not investigated further. 
The diterpene-rich extract ( $5.90 \mathrm{~g})$ was separated on VLC column 1 using gradient mixtures of cyclohexane-EtOAc-EtOH to afford 55 fractions (A1-55). Combined fractions A21-32 were submitted to VLC column 8 and eluted with decreasingly polar mixtures of $\mathrm{MeOH}-\mathrm{H}_{2} \mathrm{O}$ to yield 45 subfractions (B1-45). Purification of subfraction B20 by RP-HPLC method 5 furnished EUD-6 (11) ( $t_{R}: 6.8$ min, 23.1 $\mathrm{mg}$ ) and EUD-4 (2) ( $\mathrm{t}_{\mathrm{R}}: 8.5 \mathrm{~min}, 83.0 \mathrm{mg}$ ). Pooled subfractions B21-25 were chromatographed under the same conditions to provide EUD-8 (1) ( $t_{R}: 11.5 \mathrm{~min}, 177.4 \mathrm{mg}$ ) and an additional portion of EUD-4 (2) (35.3 mg). Further separation of subfractions B29-36 was carried out on silica gel with mobile phase 1 to give EUD-19 (3) (9.4 mg). Subfractions B49-56 were sequentially purified by PLC over NP- and RP silica gel, using corresponding mobile phases 2 and 6, to isolate EUD-16 (4) (3.2 mg) and EUD-10 (5) (5.1 mg).

Combined fractions A38-47 were loaded onto VLC column 9 and was eluted with a gradient of $\mathrm{MeOH}-$ $\mathrm{H}_{2} \mathrm{O}$ to collect 62 subfractions (C1-62). Subfractions C32-42 were fractionated on VLC column 2 by toluene- $\mathrm{CHCl}_{3}-\mathrm{Me}_{2} \mathrm{CO}$ mixtures to yield 27 subfractions (D1-27). The eluates D6-7 and D8-10 were subjected to RP-HPLC method 6 to obtain EUD-2 (10) ( $t_{R}: 7.2 \mathrm{~min}, 8.2 \mathrm{mg}$ ) and EUD-3 (9) ( $\mathrm{t}_{\mathrm{R}}: 8.6 \mathrm{~min}$, $8.0 \mathrm{mg}$ ). Consecutive purification of subfractions D11-24 first by PLC with the use of mobile phase 3, and finally by RP-HPLC method 7 led to the isolation of pure compounds EUD-22 (8) ( $t_{R}: 9.2 \mathrm{~min}, 8.5$ $\mathrm{mg})$, EUD-21 (7) ( $\mathrm{t}_{\mathrm{R}}: 12.5 \mathrm{~min}, 16.8 \mathrm{mg}$ ), and EUD-23 (6) ( $\left.\mathrm{t}_{\mathrm{R}}: 17.4 \mathrm{~min}, 22.1 \mathrm{mg}\right)$.

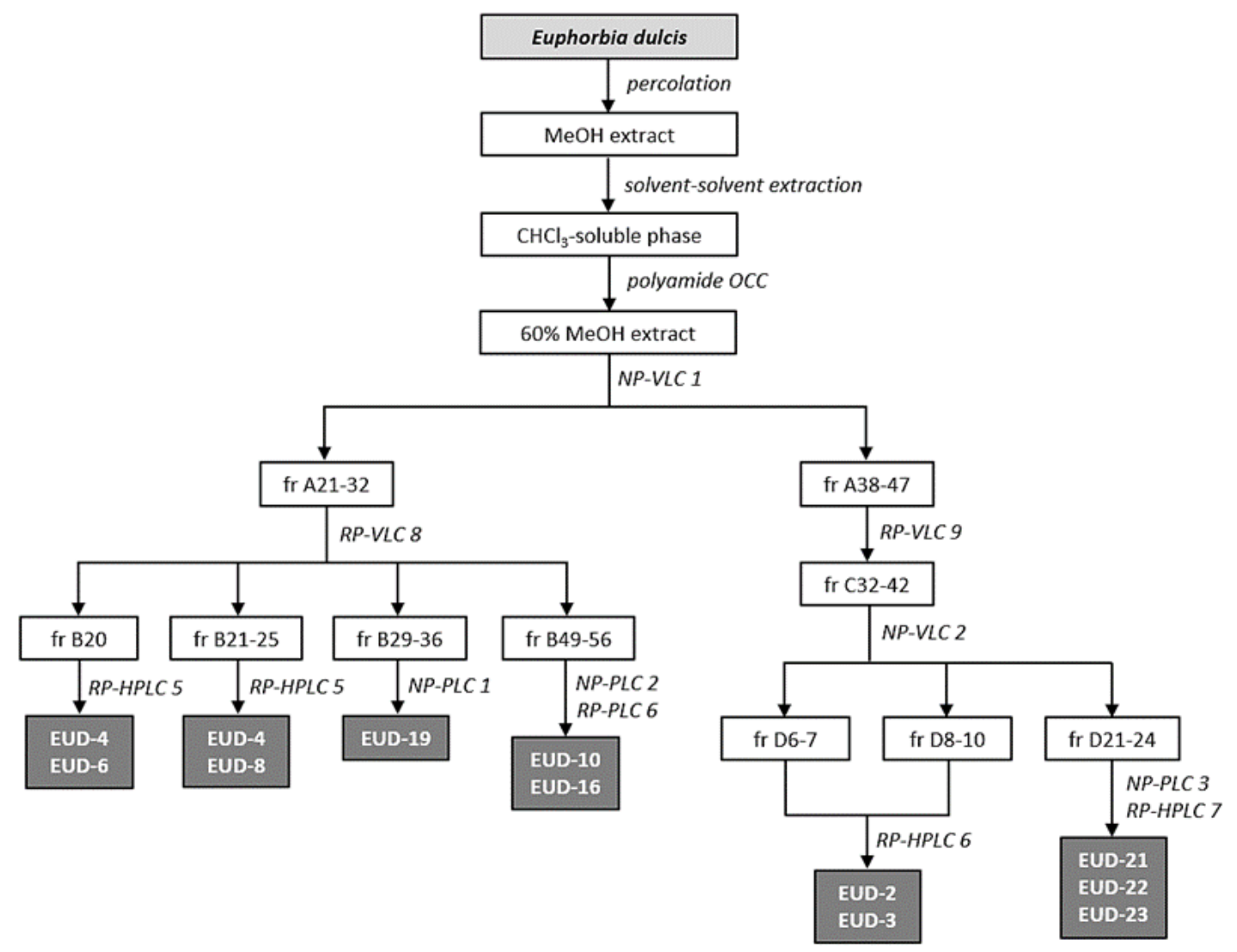

Figure 6. Isolation of diterpenoids from Euphorbia dulcis 


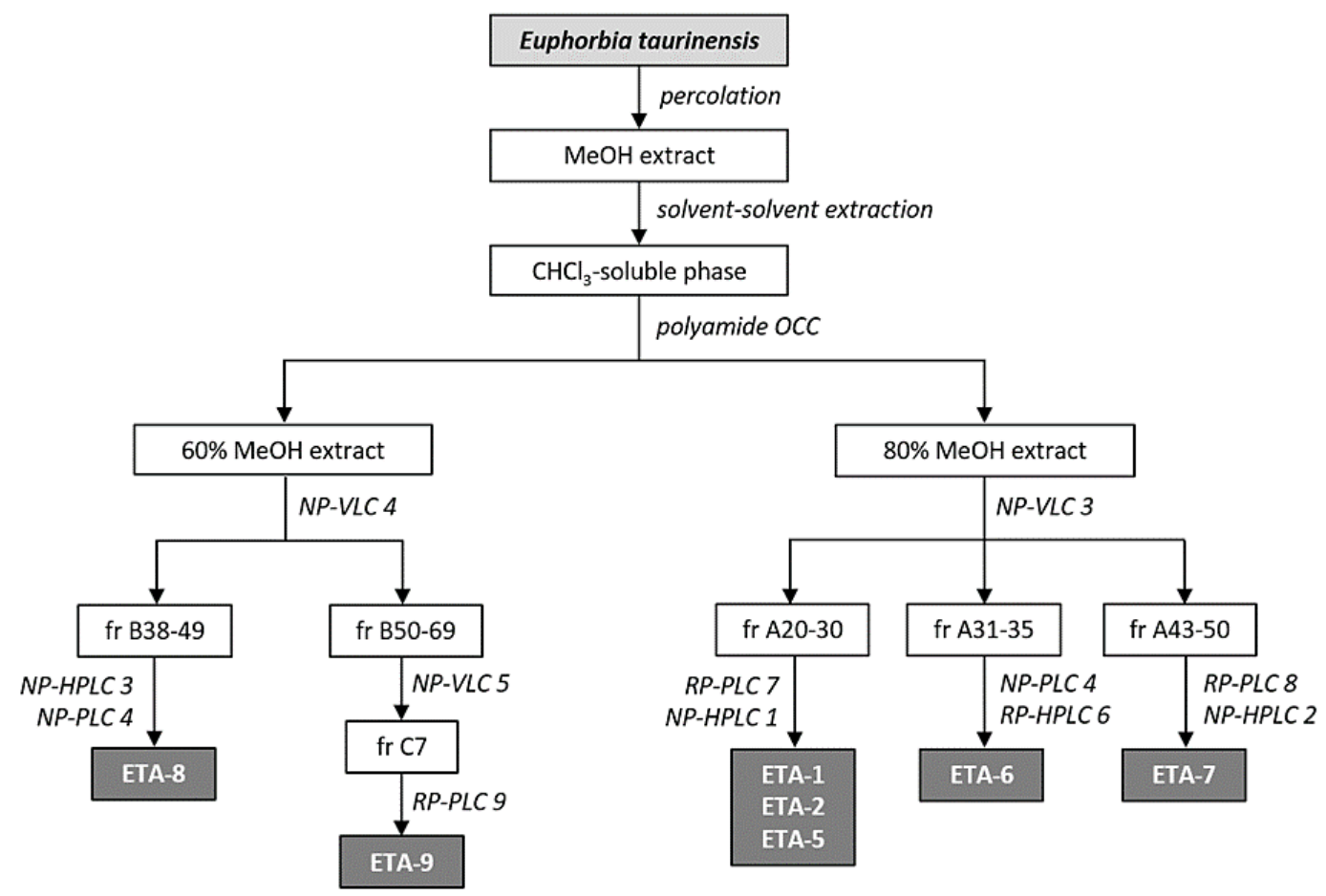

Figure 7. Isolation of diterpenoids from Euphorbia taurinensis

\subsubsection{Isolation of diterpenoids from $E$. taurinensis}

The fresh whole plants of $E$. taurinensis were grinded and percolated with $\mathrm{MeOH}$ at room temperature. After concentration in vacuo, the crude extract was diluted with $\mathrm{H}_{2} \mathrm{O}$ and partitioned with $\mathrm{CHCl}_{3}$. The organic phase on evaporation to dryness left a syrupy residue (16.65 g), which was separated by polyamide $\mathrm{OCC}$ with mixtures of $\mathrm{MeOH}-\mathrm{H}_{2} \mathrm{O}$ (Figure 7). Visualization of the collected fractions demonstrated that the diterpenoids occurred in both of the $60 \%$ and $80 \% \mathrm{MeOH}$ fractions.

The fraction obtained with $\mathrm{MeOH}-\mathrm{H}_{2} \mathrm{O}$ (3:2) was transferred onto silica gel vacuum column 4 and eluted in a gradient manner with cyclohexane-EtOAc-EtOH to collect 80 fractions (B1-80). Pooled fractions B38-49 were first subjected to NP-HPLC (method 3), then the compound observed at retention time of $6.2 \mathrm{~min}$ was rechromatographed on silica gel plates using mobile phase 4 to furnish ETA-8 (12) (12.9 mg). Combined fractions B50-69 were successfully separated on VLC column 5 with a gradient solvent system composed of cyclohexane- $\mathrm{CHCl}_{3}-\mathrm{Me}_{2} \mathrm{CO}$ to yield 51 subfractions (C1-51). $\mathrm{C7}$ was further purified by PLC (mobile phase 9) to afford ETA-9 (14) (12.1 mg).

The $80 \%$ methanolic extract was initially fractionated on VLC column 3 by eluting with a stepwise gradient of cyclohexane-EtOAc-EtOH to collect 70 fractions (A1-70). Fractions A20-30 were developed on silica gel plates with mobile phase 7 , and at the next step the proper separation of ETA-5 (15) $\left(t_{R}\right.$ : $5.3 \mathrm{~min}, 5.4 \mathrm{mg}$ ), ETA-1 (16) ( $t_{\mathrm{R}}: 6.7 \mathrm{~min}, 1.8 \mathrm{mg}$ ), and ETA-2 (17) ( $\mathrm{t}_{\mathrm{R}}: 7.4 \mathrm{~min}, 5.1 \mathrm{mg}$ ) was performed by HPLC method 1. Combined fractions A31-35 were repeatedly chromatographed on silica gel plates 
with mobile phase 4 and by RP-HPLC method 6 to obtain ETA-6 (13) ( $t_{R}: 5.5 \mathrm{~min}, 1.7 \mathrm{mg}$ ). Final purification of the main diterpenoid constituent of fractions A43-50, ETA-7 (18) ( $\left.t_{R}: 7.1 \mathrm{~min}, 2.1 \mathrm{mg}\right)$ was achieved by PLC (mobile phase 8) and NP-HPLC (method 2).

\subsubsection{Isolation of diterpenoids from E. guyoniana}

The dried aerial parts of E. guyoniana ( $45 \mathrm{~g}$ ) were powdered and thoroughly extracted with $\mathrm{CHCl}_{3}$ in an ultrasonic bath at room temperature. The crude extract was concentrated in vacuo to give a brown viscous residue (1.15 g). Rough fractionation of the lipophilic phase was performed by polyamide OCC using $\mathrm{MeOH}-\mathrm{H}_{2} \mathrm{O}$ mixtures as mobile phase (Figure 8). The TLC investigation showed that diterpenoids were present only in the $60 \%$ methanolic extract, which was further fractionated on NP-VLC column 6 by eluting with a gradient of cyclohexane-EtOAc-EtOH to collect 46 fractions. Purification of combined fractions $17-21$ by chromatographic techniques of NP-HPLC method 4 and RP-HPLC method 8 furnished EGU-4 (19) $(3.0 \mathrm{mg})$, detected at $4.2 \mathrm{~min}$ and $7.1 \mathrm{~min}$ retention times, respectively. By using the same HPLC methods, combined fractions 22-26 gave EGU-3 (20) (3.3 mg), observed at respective retention times $5.4 \mathrm{~min}$ and $5.7 \mathrm{~min}$.

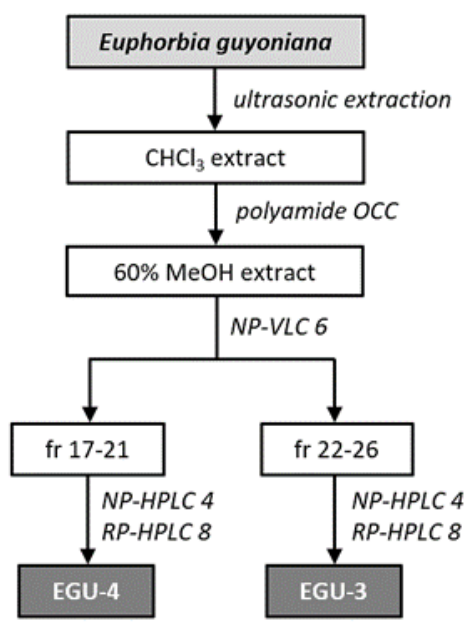

Figure 8. Isolation of diterpenoids from Euphorbia guyoniana

\subsubsection{Isolation of flavonoids from $E$. davidii}

The frozen plant material was grinded, percolated with $\mathrm{MeOH}$ at room temperature, then the solvent was evaporated under reduced pressure. The crude extract (182.55 g) was resuspended in $\mathrm{H}_{2} \mathrm{O}$ and subjected to a repetitive liquid-liquid extraction using $\mathrm{CHCl}_{3}$ and EtOAc (Figure 9). The latter phase was separated over VLC column 7 by eluting with mixtures of EtOAc-EtOH- ${ }_{2} \mathrm{O} .120$ fractions were collected, from which fraction 4, 5, and 6 with high content of flavonoids were further separated by PLC using mobile phase 5, and then by RP-HPLC method 9. The peaks collected at 5.3, 6.2, and 7.3 min 
retention times afforded EDI-17 (21) $(3.0 \mathrm{mg})$, EDI-18 (22) $(3.0 \mathrm{mg})$, and EDI-19 (23) (3.0 mg), respectively.

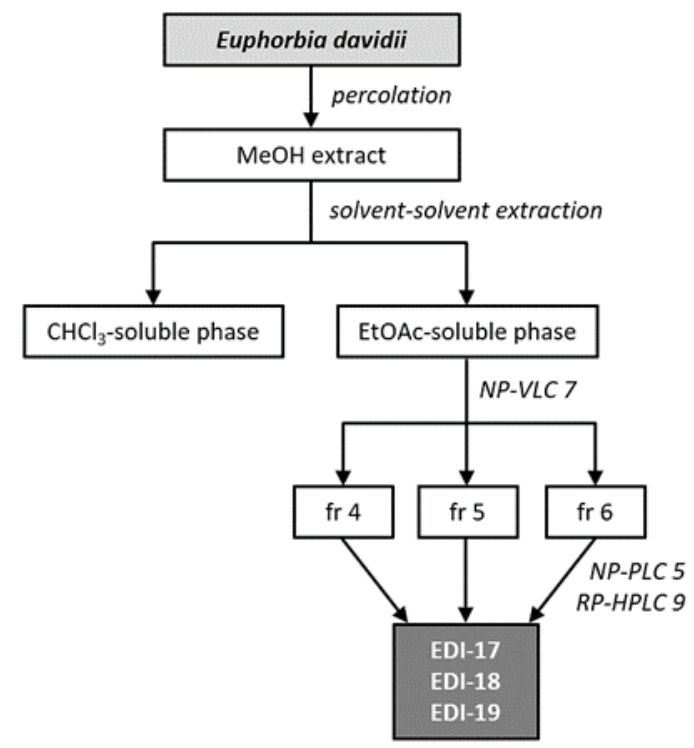

Figure 9. Isolation of flavonoid glycosides from Euphorbia davidii

\subsection{Structure determination of the isolated compounds}

$\operatorname{EUD}-8(\mathbf{1})$

The molecular formula of EUD-8 (1) was assigned as $\mathrm{C}_{36} \mathrm{H}_{48} \mathrm{O}_{9}$ by the peak of the protonated molecule at $\mathrm{m} / \mathrm{z} 625.3371\left[\mathrm{M}+\mathrm{H}^{+}\right.$(calcd 625.3377; HRESIMS data of the novel compounds isolated from E. dulcis, E. taurinensis, and E. guyoniana are summarized in Annex 1). Its ${ }^{1} \mathrm{H}$ and JMOD NMR spectra displayed characteristic signals of a benzoyl $\left(\delta_{\mathrm{H}} 7.98 \mathrm{~d}, 7.49 \mathrm{t}, 7.38 \mathrm{t} ; \delta_{\mathrm{c}} 165.8,132.8,130.4,130.0\right.$, 128.5), two acetyl $\left(\delta_{\mathrm{H}} 2.19 \mathrm{~s}, 1,86 \mathrm{~s} ; \delta_{\mathrm{C}} 171.4,169.5,2 \times 21.2\right)$, and a tigloyl group $\left(\delta_{\mathrm{H}} 6.50 \mathrm{q}, 1.28 \mathrm{~d}\right.$, $1.23 \mathrm{~s} ; \delta_{\mathrm{c}} 166.6,137.8,128.1,14.3,11.4$; for comprehensive 1D NMR data of 1-9, see Annexes 2 and 3). Besides the ester functionalities, the JMOD spectrum contained the resonances of 20 carbons attributable to a diterpene core. The HSQC spectrum showed that the skeleton of 1 comprises five methyls, two methylenes, seven methines (including four oxymethines), and three olefinic carbons. The resonances at $\delta_{c}$ 135.1, 84.0, and 40.2 that did not exhibit any correlations were classified as a nonprotonated $\mathrm{sp}^{2}$, an oxygenated tertiary, and a quaternary carbon, respectively. The ${ }^{1} \mathrm{H}-{ }^{1} \mathrm{H}$ COSY and HSQC spectra suggested the presence of a disubstituted $\left(\delta_{\mathrm{H}} 5.65 \mathrm{dd}, 5.11 \mathrm{~d} ; \delta_{\mathrm{C}} 129.6,138.3\right)$ and a trisubstituted $\left(\delta_{\mathrm{H}} 5.69 \mathrm{~d} ; \delta_{\mathrm{C}} 119.8,135.1\right)$ olefinic bond in the diterpenoid scaffold. Apart from the benzoyl and tigloyl groups, COSY cross-peaks revealed three further sequences of correlated protons: $-\mathrm{CH}_{2}-\mathrm{CH}\left(\mathrm{CH}_{3}\right)-\mathrm{CH}(\mathrm{OR})-\mathrm{CH}-\mathrm{CH}=\left(\delta_{\mathrm{H}} 2.04 \mathrm{~m}, 1.74 \mathrm{~m}, 2.11 \mathrm{~m}, 0.90 \mathrm{~d}, 5.38 \mathrm{br} \mathrm{s}, 2.89 \mathrm{dd}, 5.69 \mathrm{~d}\right)[A]$, $-\mathrm{CH}(\mathrm{OR})-\mathrm{CH}_{2}-\mathrm{CH}(\mathrm{OR})-\left(\delta_{\mathrm{H}} 5.08 \mathrm{br} \mathrm{s}, 1.99 \mathrm{~m}, 4.86 \mathrm{br} \mathrm{s}\right)[B]$, and $-\mathrm{CH}=\mathrm{CH}-\mathrm{CH}\left(\mathrm{CH}_{3}\right)-\mathrm{CH}(\mathrm{OR})-\left(\delta_{\mathrm{H}} 5.11 \mathrm{~d}\right.$, $5.65 \mathrm{dd}, 2.56 \mathrm{~m}, 0.94 \mathrm{~d}, 4.91 \mathrm{~d}$ ) [C]. In addition, a weak ${ }^{4} \mathrm{~J}_{\mathrm{H}-\mathrm{H}}$ (W-type) correlation between the protons 
resonating at $\delta_{\mathrm{H}} 5.69$ and 1.75 indicated their close proximity. ${ }^{184}$ According to the molecular formula, a bicyclic ring system was proposed for compound $\mathbf{1}$ in order to satisfy the 13 indices of hydrogen deficiency. Connectivities of partial structures were determined by means of an HMBC experiment. The two- and three-bond correlations of $\mathrm{H}-1 \mathrm{a} / \mathrm{b}, \mathrm{H}-3$, and $\mathrm{H}-4$ with $\mathrm{C}-15\left(\delta_{\mathrm{c}} 84.0\right)$, together with $\mathrm{H}$ 14/C-1 proved that segment $A$ forms a methyl-substituted cyclopentane moiety present in many types of Euphorbiaceae diterpenoids. ${ }^{30}$ The cross-peaks of $\mathrm{H}_{3}-17$ with $\mathrm{C}-5, \mathrm{C}-6\left(\delta_{\mathrm{C}} 135.1\right)$, and $\mathrm{C}-7$, as well as between $\mathrm{H}-9, \mathrm{H}-12, \mathrm{H}_{3}-18, \mathrm{H}_{3}-19$, and $\mathrm{C}-10\left(\delta_{\mathrm{C}} 40.2\right)$ demonstrated that subunits $A-C$ and two geminal methyls are involved in the formation of a 12-membered macrocycle characteristic of a jatrophane diterpenoid core. In view of the aforementioned $\mathrm{HMBC}$ interactions of the deshielded $\mathrm{H}_{3}-17\left(\delta_{\mathrm{H}} 1.75\right)$ and the lack of exomethylene signals, it was concluded that compound 1 contains a rare $\Delta^{(5,6)}$ olefinic bond instead of the regular $\Delta^{(6,17)}$ double bond. The locations of the ester substituents were determined by the correlations of skeletal oxymethines $\mathrm{H}-3, \mathrm{H}-7, \mathrm{H}-9$, and $\mathrm{H}-14$ with carbonyl carbons at $\delta_{\mathrm{C}} 165.8$ (benzoyl), 166.6 (tigloyl), 169.5, and 171.4 (acetyls), respectively. Although we did not observe any exhangeable proton signal in the ${ }^{1} \mathrm{H}$ NMR spectrum, the molecular formula and $\delta_{\mathrm{C} 15}$ at 84.0 clearly required the presence of a hydroxy group at C-15.

The relative configuration of compound 1 was assessed by analysing the NOESY spectrum and the pattern of coupling constants. A set of NOE cross-peaks of the frequently chosen reference $\mathrm{H}-4 \alpha$ with $\mathrm{H}-2, \mathrm{H}-3, \mathrm{H}-13$, and $\mathrm{H}-14$ dictated the $\beta$-orientation of the secondary methyls $\mathrm{H}_{3}-16$ and $\mathrm{H}_{3}-20$, the $\mathrm{C}-3$ benzoyl, and the $\mathrm{C}-14$ acetyl groups. ${ }^{185}$ The $\mathrm{C}-1$ geminal protons were distinguished via the $\mathrm{H}-1 \alpha / \mathrm{H}-14$ and $\mathrm{H}-1 \beta / \mathrm{H}_{3}-16$ NOE correlations. The large coupling constant between $\mathrm{H}-4$ and $\mathrm{H}-5\left({ }^{3} \mathrm{~J}_{\mathrm{H}-5}=10.4 \mathrm{~Hz}\right)$ suggested their location on the opposite sides of the molecule. ${ }^{127}$ With regard to the diagnostic NOE signals $\mathrm{H}-4 / \mathrm{H}_{3}-17$ and $\mathrm{H}-5 / \mathrm{H}-9$, as well as the absence of an $\mathrm{H}-5 / \mathrm{H}_{3}-17$ correlation, the trisubstituted $\Delta^{(5,6)}$ olefinic bond must have an $E$-configuration. ${ }^{24,185}$ The $E$ stereochemistry of the $\Delta^{(11,12)}$ double bond was evident from the large value of ${ }^{3} J_{\mathrm{H} 11-12}(15.8 \mathrm{~Hz})$. This finding was further corroborated by NOE cross-peaks of $\mathrm{H}-11$ with $\mathrm{H}-13$ and $\mathrm{H}_{3}-19$, and of $\mathrm{H}-12$ with $\mathrm{H}_{3}-18 .{ }^{24,106}$ The strong NOEs between $\mathrm{H}-$ $7 / \mathrm{H}_{3}-17, \mathrm{H}-5 / \mathrm{H}-9$, and $\mathrm{H}-9 / \mathrm{H}_{3}-18$ confirmed the $\beta$-orientation of the $\mathrm{C}-7$ tigloyl and the $\alpha$-position of the $\mathrm{C}-9$ acetyl groups, respectively. ${ }^{114,184} \mathrm{H}_{3}-20$ was presumed to occupy an equatorial-like position from its NOEs with $\mathrm{H}-14$, and from the missing $\mathrm{H}-11 / \mathrm{H}_{3}-20$ interaction. ${ }^{127,186}$ The $\mathrm{C}-15$ hydroxy group was assigned as $\beta$-oriented based on the fact that all of the jatrophane diterpenoids isolated to date contain a trans-fused bicyclo[10.3.0]pentadecane ring system. ${ }^{113}$ The rather sharp proton and carbon signals indicated that molecules with endo- and exo-conformations were undergoing fast interconversions and rapid equilibrium in solution. ${ }^{83,127}$ Considering the large value of ${ }^{3}{ }_{H 4-5}$, the NOE correlation between $\mathrm{H}-4$ and $\mathrm{H}_{3}-17$, and the restricted rotation around the $\mathrm{C}-5 / \mathrm{C}-6$ axis, it was certain that the $\mathrm{H}_{3}-17$ methyl is predominantly orthogonal to the mean plane of the macrocycle, implying that compound 1 preferentially adopted an endo-type conformation. ${ }^{83}$ 

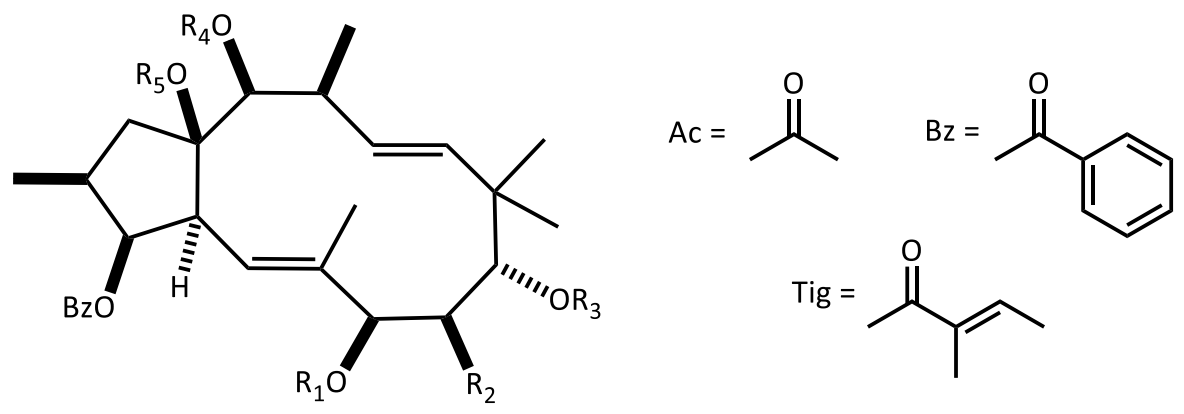

\begin{tabular}{|c|c|c|c|c|}
\hline & $\mathbf{R}_{\mathbf{1}}$ & $\mathbf{R}_{\mathbf{2}}$ & $\mathbf{R}_{3}$ & $\mathbf{R}_{\mathbf{4}}$ \\
\hline 1 (EUD-8) & Tig & $\mathrm{H}$ & $A c$ & $A c$ \\
\hline 2 (EUD-4) & Tig & OAC & $A c$ & $A c$ \\
\hline 3 (EUD-19) & Tig & OAC & $A c$ & Tig \\
\hline 4 (EUD-16) & $\mathrm{H}$ & OAC & $A c$ & Tig \\
\hline 5 (EUD-10) & $\mathrm{H}$ & OAC & $A c$ & $A c$ \\
\hline 6 (EUD-23) & Ac & $\mathrm{OH}$ & $A c$ & Ac \\
\hline 7 (EUD-21) & $A c$ & $\mathrm{OH}$ & $\mathrm{H}$ & $A c$ \\
\hline 8 (EUD-22) & $\mathrm{H}$ & $\mathrm{OH}$ & $\mathrm{H}$ & $A c$ \\
\hline 9 (EUD-3) & $A c$ & OAC & $A c$ & $\mathrm{H}$ \\
\hline 10 (EUD-2) & $A c$ & OAC & $A c$ & $A c$ \\
\hline 11 (EUD-6) & $A c$ & $\mathrm{H}$ & $A c$ & $A C$ \\
\hline
\end{tabular}

The absolute configuration of compound 1 was determined by single-crystal X-ray diffraction. A minuscule crystal with the size of $0.02 \times 0.02 \times 0.15 \mathrm{~mm}$ was mounted on a Kapton loop (for details of the crystallization procedure and the crystalline structure of $\mathbf{1}$, see Appendix I). Compound 1 crystallized in the monoclinic chiral space group $P 2_{1}$ with three crystallographically independent but chemically identical conformers in the asymmetric unit (Figure 10A). The conformational differences of the core are negligible despite the flexible 12-membered macrocycle, only the atomic positions at the terminal part of ester functions differ. The absolute configuration has been established in the diffraction measurement based on the anomalous dispersion effect of the nine oxygen atoms present in the diterpenoid. For all three conformers of $\mathbf{1}$, the assignment is most likely

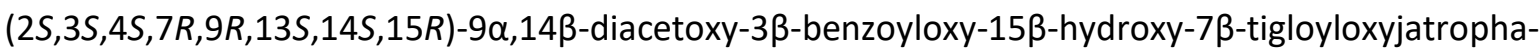

$5 E, 11 E$-diene (Figure 10B). As demonstrated by the NOESY and X-ray diffraction experiments, the conformers of compound $\mathbf{1}$ in the crystal state were in good agreement with the dominant conformer presents in solution. 


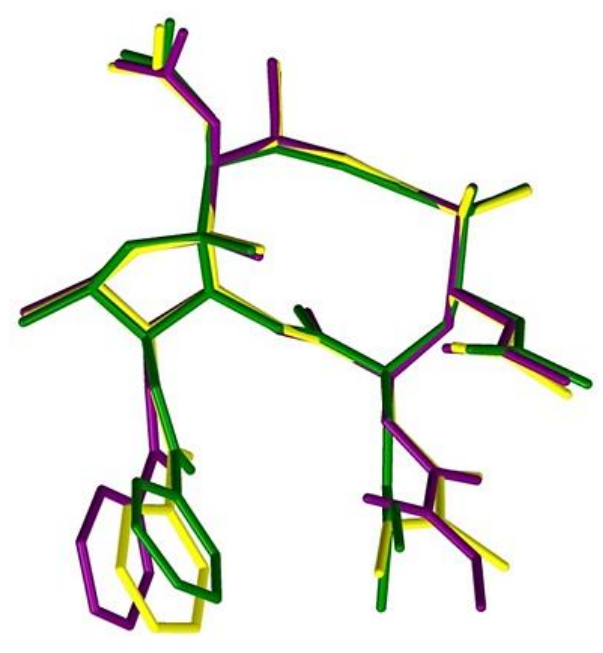

A

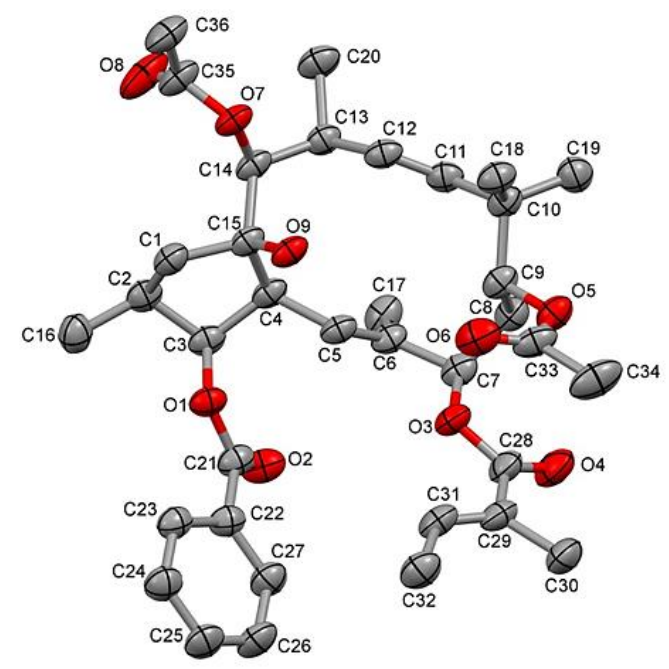

B

Figure 10. Panel A: Molecular overlay of the three conformers in the asymmetric unit. Panel B: Molecular structure of compound $\mathbf{1}$ with atomic labelling. The displacement ellipsoids are drawn at the $50 \%$ probability level.

EUD-4 (2)

The molecular formula of EUD-4 (2) was determined to be $\mathrm{C}_{38} \mathrm{H}_{50} \mathrm{O}_{11}$ by the HRESIMS ion at $\mathrm{m} / \mathrm{z}$ $705.3281[\mathrm{M}+\mathrm{Na}]^{+}($calcd 705.3251). Comparison of the NMR spectroscopic data of $\mathbf{1}$ and $\mathbf{2}$ indicated that the structures of these diterpenoids differ only in an acetoxy group. This conclusion was based on the presence of the additional oxymethine signal at $\delta_{\mathrm{H}} 5.14$ and methyl resonance at $\delta_{\mathrm{H}} 2.04$, which gave $\mathrm{HMBC}$ correlations with a carbonyl carbon at $\delta_{\mathrm{C}} 172.0$. The ${ }^{1} \mathrm{H}-{ }^{1} \mathrm{H}$ COSY spectrum defined subunit $B$ as $-\mathrm{CH}(\mathrm{OR})-\mathrm{CH}(\mathrm{OR})-\mathrm{CH}(\mathrm{OR})-\left(\delta_{\mathrm{H}} 5.08 \mathrm{br} \mathrm{s}, 5.14 \mathrm{br} \mathrm{s}, 5.31 \mathrm{br}\right.$ s). HMBC cross-peaks of H-7/C-8, H-8/C9, and $\mathrm{H}-8 / \mathrm{C}-10$ further confirmed that the above-mentioned acetoxy moiety is attached to $\mathrm{C}-8$. Interestingly, the hydrogen signals of segment $B$ appeared as broad singlets. The small or even zero ${ }^{3} J_{\mathrm{H7}-8}$ and ${ }^{3}{ }_{\mathrm{H} 8-9}$ coupling constants are characteristic of the 7,8,9-trisubstituted jatrophanes, and can be explained by the nearly $90^{\circ}$ dihedral angles between $\mathrm{H}-7 / \mathrm{H}-8$ and $\mathrm{H}-8 / \mathrm{H}-9 .{ }^{79}, 185$ The key heteronuclear correlations depicted in Figure $\mathbf{1 1}$ established the connectivities of spin systems $A-C$ through nonprotonated carbons at $\delta_{\mathrm{C}} 132.2$ (C-6), 84.3 (C-15), and 41.0 (C-10), and the locations of the esterifying groups on the diterpenoid core. The $\beta$-orientation of 8-OAc was shown by NOEs of H-8 with $\mathrm{H}_{3}-17$ and $\mathrm{H}_{3}-19,{ }^{24,129}$ while the other eight asymmetric carbons were found to be identical with those of compound 1. 


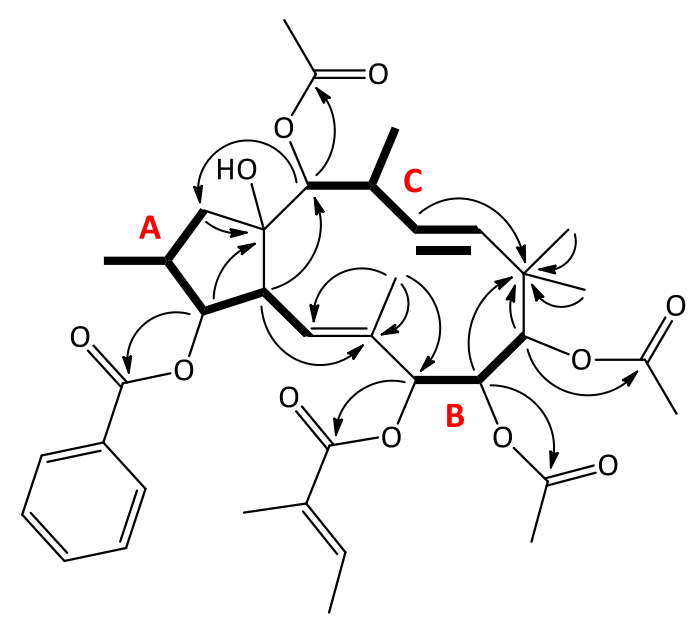

Figure 11. Relevant 2D correlations of compound 2. Bold bonds indicate COSY interactions between adjacent skeletal protons, while arrows $(\mathrm{C} \rightarrow \mathrm{H})$ illustrate $\mathrm{HMBC}$ cross-peaks.

EUD-19 (3)

EUD-19 (3) has the molecular formula $\mathrm{C}_{41} \mathrm{H}_{54} \mathrm{O}_{11}$ compatible with its sodiated HRESIMS ion at $\mathrm{m} / \mathrm{z}$ $745.3596[\mathrm{M}+\mathrm{Na}]^{+}$(calcd 745.3564). Preliminary investigation of the ${ }^{1} \mathrm{H}$ and JMOD spectra indicated the presence of a jatrophane parent system esterified with a benzoic, two acetic, and two tiglic acids. The HMBC cross-peaks of $\mathrm{H}-3, \mathrm{H}-7, \mathrm{H}-8, \mathrm{H}-9$, and $\mathrm{H}-14$ with carbonyl signals at $\delta_{\mathrm{c}} 167.4$ (benzoyl), 168.2 (tigloyl), 172.1, 171.6 (acetyls), and 170.0 (tigloyl), respectively, revealed the location of ester groups on the highly oxygenated terpenoid core. The proton resonances of 7-O-Tig $\left(\delta_{\mathrm{H}} 6.57 \mathrm{q}, 1.30 \mathrm{br} \mathrm{d}, 1.25\right.$ s) were significantly shielded compared to those of $14-O-T i g\left(\delta_{H} 7.07 \mathrm{dq}, 1.92 \mathrm{br} \mathrm{s}, 1.87 \mathrm{~d}\right)$, which was caused by the anisotropic effect of the cis-located C-3 aromatic substituent. ${ }^{187}$ NOEs permitted assignment of the same relative configurations of the stereogenic carbons as in compounds $\mathbf{1}$ and $\mathbf{2}$.

\section{EUD-16 (4)}

The molecular formula of EUD-16 (4) was determined to be $\mathrm{C}_{36} \mathrm{H}_{48} \mathrm{O}_{10}$ in accordance with its HRESIMS sodium adduct ion at $m / z 663.3172[\mathrm{M}+\mathrm{Na}]^{+}$(calcd 663.3145). The ${ }^{1} \mathrm{H}$ NMR spectrum contained the signals of a benzoyl, two acetyls, and a tigloyl group. The lack of diamagnetic shifted signals attributed to 7-O-Tig and a hydrogen resonance at $\delta_{\mathrm{H}} 3.78$ with no HSQC cross-peak demonstrated that the difference between $\mathbf{4}$ and $\mathbf{3}$ was restricted to the absence of an acyl residue at C-7. This hydroxy group was involved in the formation of subunit $B$ as follows: $-\mathrm{CH}(\mathrm{OH})-\mathrm{CH}(\mathrm{OR})-\mathrm{CH}(\mathrm{OR})-\left(\delta_{\mathrm{H}} 3.99 \mathrm{~d}, 3.78 \mathrm{br}\right.$, $5.15 \mathrm{~d}, 4.54 \mathrm{~d}$ ), and was assigned as $\beta$-oriented based on the strong $7-\mathrm{OH} / \mathrm{H}-9, \mathrm{H}-7 / \mathrm{H}-8$, and $\mathrm{H}-7 / \mathrm{H}_{3}-17$ NOE interactions. 
EUD-10 (5)

HRESIMS suggested the molecular formula $\mathrm{C}_{33} \mathrm{H}_{44} \mathrm{O}_{10}$ for EUD-10 (5) via the sodium adduct ion at $\mathrm{m} / \mathrm{z}$ 623.2858 [M + Na $]^{+}$(calcd 623.2832). The 1D NMR spectra displayed signals of a benzoyl and three acetyl groups. The proton and carbon chemical shifts of structural segments $A-C$ were virtually the same as those of compound 4. The HMBC correlations of skeletal oxymethines $\mathrm{H}-3, \mathrm{H}-8, \mathrm{H}-9$, and $\mathrm{H}-14$ with ester carbonyls at $\delta_{\mathrm{C}} 166.7$ (benzoyl), 169.9, 172.2, and 171.2 (acetyls) provided key information regarding the locations of substituents on the diterpenoid backbone. Thus, compound $\mathbf{5}$ was assignable as the $14-0$-acetyl analogue of 4 .

EUD-23 (6)

The sodiated ion at $m / z 623.2816[\mathrm{M}+\mathrm{Na}]^{+}$(calcd 623.2832) showed that compound 6 has the same molecular formula as 5. Taking into account the 1D NMR signals of one benzoyl and three acetyl groups, it was assumed that $\mathbf{6}$ is an isomer of 5. Because of the heavily overlapping hydrogen signals in $\mathrm{CD}_{3} \mathrm{OD}$ or $\mathrm{CDCl}_{3}$, pyridine- $d_{5}$ was chosen as solvent for the $2 \mathrm{D}$ NMR measurements. Although the chemical shifts of $\mathbf{5}$ and $\mathbf{6}$ were not directly comparable, differences in subunits $B$ of the two compounds $\left[-\mathrm{CH}(\mathrm{OR})-\mathrm{CH}(\mathrm{OH})-\mathrm{CH}(\mathrm{OR})-\left(\delta_{\mathrm{H}} 5.51 \mathrm{br} \mathrm{s}, 4.28 \mathrm{~d},-\mathrm{OH} 5.70 \mathrm{~d}, 5.63 \mathrm{br} s\right)\right.$ in 6 and $-\mathrm{CH}(\mathrm{OH})-\mathrm{CH}(\mathrm{OR})-\mathrm{CH}(\mathrm{OR})-$ in 5] were quickly revealed by the COSY spectra. The HMBC cross-peaks of $\mathrm{H}-3, \mathrm{H}-7, \mathrm{H}-9$, and H-14 with carbonyl carbons at $\delta_{\mathrm{C}} 166.1$ (benzoyl), 170.0, 169.6, and 171.8 (acetyls) placed the ester functions at C-3, C-7, C-9, and C-14. The location of 7-OAc in the shielding cone of C3 cis-benzoyl group was demonstrated by its upfield shifted methyl protons $\left(\delta_{\mathrm{H}} 1.32\right.$ vs. $\delta_{\mathrm{H}} 2.13-9$ $\mathrm{OAc}$, and $2.12-14-\mathrm{OAc}){ }^{185}$

EUD-21 (7)

The HRESIMS ion at $m / z 581.2732\left[\mathrm{M}+\mathrm{Na}^{+}\right.$(calcd 581.2727) provided the molecular formula $\mathrm{C}_{31} \mathrm{H}_{42} \mathrm{O}_{9}$ for EUD-21 (7), which could be derived from 6 by the loss of an acetyl unit. The 1D NMR spectra supported this deduction, as it displayed proton and carbon resonances ascribable to a benzoyl and two acetyl functions. As explained above, the diamagnetic shifted acetyl at $\delta_{\mathrm{H}} 1.25$ has to be attached to $\mathrm{C}-7$. Mutual ${ }^{1} \mathrm{H}-{ }^{1} \mathrm{H}$ COSY couplings between hydroxy groups $\left(\delta_{\mathrm{H}} 4.12 \mathrm{br}, 2.70 \mathrm{~d}\right)$ and neighbouring oxymethines $\mathrm{H}-8$ and $\mathrm{H}-9$ established substructure $B$ with a vicinal diol moiety $[-\mathrm{CH}(\mathrm{OR})-\mathrm{CH}(\mathrm{OH})-\mathrm{CH}(\mathrm{OH})-]$. The long-range $\mathrm{HMBC}$ interactions of $\mathrm{H}-3, \mathrm{H}-7$, and $\mathrm{H}-14$ with carbonyl signals at $\delta_{\mathrm{C}} 165.6,172.5$, and 171.3 determined the positions of benzoyloxy and acetoxy groups at the corresponding carbons $\mathrm{C}-3, \mathrm{C}-7$, and C-14. 
EUD-22 (8)

The molecular formula $\mathrm{C}_{29} \mathrm{H}_{40} \mathrm{O}_{8}$ was assigned to EUD-22 (8) with respect to its sodium adduct ion [M + $\mathrm{Na}^{+}$observed at $\mathrm{m} / \mathrm{z} 539.2644$ (calcd 539.2621). Its 1D NMR spectra exhibited the signals of a benzoyl and an acetyl group. Considering the HMBC cross peak of $\mathrm{H}-14$ with a carbonyl carbon at $\delta_{\mathrm{c}} 171.3$, the latter function was placed onto C-14.

\section{EUD-3 (9)}

The sodium adduct ion detected at $m / z 665.2960[\mathrm{M}+\mathrm{Na}]^{+}($calcd 665.2938$)$ in the HRESIMS data of EUD-3 (9) suggested the molecular formula $\mathrm{C}_{35} \mathrm{H}_{46} \mathrm{O}_{11}$. Initial analysis of the ${ }^{1} \mathrm{H}, J M O D$, and HSQC spectra showed substantial differences between compounds $\mathbf{9}$ and $\mathbf{1 - 8}$, namely, the remarkable paramagnetic shifts of $\mathrm{C}-1$ geminal protons $\left(\delta_{\mathrm{H}} 2.95 \mathrm{br} \mathrm{d}, 2.14 \mathrm{~m}\right)$, the acetyl resonance at $\delta_{\mathrm{H}} 2.41$, and the oxygenated tertiary $\mathrm{C}-15$ at $\delta_{\mathrm{C}}$ 94.8. In order to elucidate the structure of compound $\mathbf{9}$, a complete series of 2D NMR spectra were recorded and analysed. It was found that 9 is a structural isomer of the known euphomelliferene $B$, in which the ester and hydroxy substituents at C-14 and C-15 were interchanged. This unusual feature was confirmed by a COSY cross-peak between $\mathrm{H}-14\left(\delta_{\mathrm{H}} 3.54\right)$ and a hydroxy signal $\left(\delta_{H} 4.93\right)$ and by the absence of three-bond HMBC correlations of the acetyl carbonyl carbon at $\delta_{\mathrm{c}} 174.3$ with protons of the diterpenoid core. The correlations of oxymethines $\mathrm{H}-3, \mathrm{H}-7, \mathrm{H}-$ 8, and $\mathrm{H}-9$ with related carbonyl carbons at $\delta_{\mathrm{C}} 164.9$ (benzoyl), 168.9, 170.2, and 169.2 (acetyls) located the four other esters at C-3, C-7, C-8, and C-9, respectively. A set of NOEs in conjunction with the missing interaction between $\mathrm{H}-4 \alpha$ and $15-\mathrm{OAc}$ revealed the same relative configurations of stereogenic carbons as determined above for compounds $\mathbf{1 - 8} .^{184}$

EUD-2 (10) and EUD-6 (11)

According to the literature data, EUD-2 (10) and EUD-6 (11) were identified as euphomelliferene B and euphornin, respectively. ${ }^{185,187}$

\section{ETA-8 (12)}

The HRESIMS ion at $m / z 679.2729[\mathrm{M}+\mathrm{Na}]^{+}($calcd 679.2731$)$ provided the molecular formula $\mathrm{C}_{35} \mathrm{H}_{44} \mathrm{O}_{12}$ for ETA-8 (12). The ${ }^{1} \mathrm{H}$ and JMOD spectra contained the signals of a benzoyl $\left(\delta_{\mathrm{H}} 7.84 \mathrm{~d}, 7.58 \mathrm{t}, 7.46 \mathrm{t}\right.$; $\delta_{\mathrm{c}}$ $166.0,133.5,129.6,129.4$, and 128.9$)$ and three acetyl groups $\left(\delta_{\mathrm{H}} 2.15 \mathrm{~s}, 2.08 \mathrm{~s}, 2.07 \mathrm{~s} ; \delta_{\mathrm{c}} 170.9,170.5\right.$, 170.2, 21.9, 21.2, and 20.6) (for comprehensive 1D NMR data of 12, see Annex 4). The presence of an acetoxyacetate group was verified by $\mathrm{HMBC}$ correlations between an isolated oxymethylene $\left(\delta_{\mathrm{H}} 4.58\right.$ d, 4.48 d) and two ester carbonyl carbons at $\delta_{C} 167.0$ and 170.2. Apart from the ester residues, 20 resonances in the JMOD spectrum were classified on the basis of their HSQC cross-peaks and chemical 
shifts as four methyls, four methylenes, seven methines (including three oxymethines), and five nonprotonated carbons. The latter signals were assigned as a keto $\left(\delta_{\mathrm{C}} 220.1\right)$, two oxygenated tertiary $\left(\delta_{c} 83.1,82.4\right)$, and two quaternary $\left(\delta_{c} 45.8,41.3\right)$ carbons, respectively. Taking into account the benzene ring and the six carbonyls of the molecule, a tetracyclic diterpenoid core was proposed for $\mathbf{1 2}$ in order to satisfy the 14 indices of hydrogen deficiency. The ${ }^{1} \mathrm{H}-{ }^{1} \mathrm{H}$ COSY spectrum defined two sequences of adjacent protons as $-\mathrm{CH}_{2}-\mathrm{CH}\left(\mathrm{CH}_{3}\right)-\mathrm{CH}(\mathrm{OR})-\mathrm{CH}-\mathrm{CH}(\mathrm{OR})-\left(\delta_{\mathrm{H}} 2.37 \mathrm{dd}, 1.54 \mathrm{dd}, 2.07 \mathrm{~m}\right.$, 0.93 d, 5.79 br s, 3.28 dd, 5.29 d) [A], $-\mathrm{CH}_{2}-\mathrm{CH}-\mathrm{CH}-\mathrm{CH}_{2}-\left(\delta_{\mathrm{H}} 2.57 \mathrm{br} \mathrm{d}, 1.28 \mathrm{t}, 3.64 \mathrm{ddd}, 1.50 \mathrm{dd}, 1.92\right.$ br d, $1.85 \mathrm{dd}$ ) [B], and a geminal proton pair ( $\delta_{\mathrm{H}} 3.54 \mathrm{~d}, 1.05 \mathrm{~d}$ ) [C] (Figure 12A). The HMBC correlations from $\mathrm{H}-1 \mathrm{~b}, \mathrm{H}-3, \mathrm{H}-5, \mathrm{H}-14$, and $15-\mathrm{OH}$ to $\mathrm{C}-15\left(\delta_{\mathrm{C}} 83.1\right)$ suggested that subunit $A$ forms a cyclopentane ring substituted with a methyl, a hydroxy, and an ester group. The long-range interactions between $\mathrm{H}$ 5, $\mathrm{H}-7 \mathrm{a} / \mathrm{b}, \mathrm{H}-17 \mathrm{a} / \mathrm{b}$, and $\mathrm{C}-6\left(\delta_{\mathrm{c}} 82.4\right)$, as well as between $\mathrm{H}-11 \mathrm{a}, \mathrm{H}-12, \mathrm{H}-14, \mathrm{H}-17 \mathrm{a} / \mathrm{b}, \mathrm{H}-20$, and C-13 $\left(\delta_{C} 41.3\right)$ indicated that spin systems $A-C$ and the oxymethine $\mathrm{H}-14$ are incorporated into a bicyclo[4.3.1] decane ring system. ${ }^{157}$ The $\mathrm{HMBC}$ cross-peaks of $\mathrm{H}-11 \mathrm{a} / \mathrm{b}, \mathrm{H}_{3}-18$, and $\mathrm{H}_{3}-19$ with $\mathrm{C}-10\left(\delta_{\mathrm{C}}\right.$ 45.8), and of $\mathrm{H}-7 \mathrm{~b}, \mathrm{H}-8, \mathrm{H}-11 \mathrm{~b}, \mathrm{H}-12, \mathrm{H}_{3}-18$, and $\mathrm{H}_{3}-19$ with $\mathrm{C}-9\left(\delta_{\mathrm{c}} 220.1\right)$ showed that the fourth ring of the terpenoid skeleton is composed of subunit $B$, a quaternary carbon attached to the gem-methyls, and a keto group. The locations of ester moieties were determined by the heteronuclear correlations of $\mathrm{H}-3, \mathrm{H}-5$, and $\mathrm{H}-14$ with carbonyl carbons at $\delta_{c} 166.0$ (benzoyl), 167.0 (acetoxyacetyl), and 170.5 (acetyl). In addition, a weak four-bond HMBC correlation of the acetyl methyl at $\delta_{\mathrm{H}} 2.07$ with C-6 established its position.

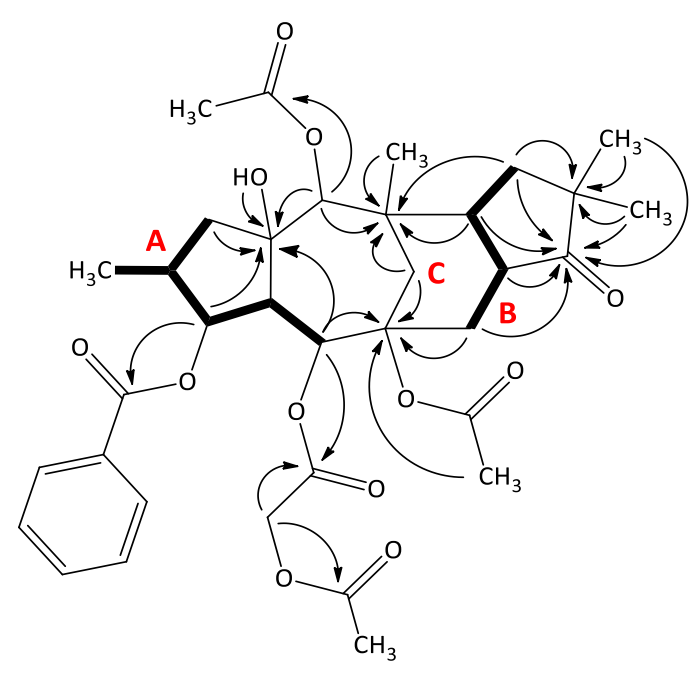

A

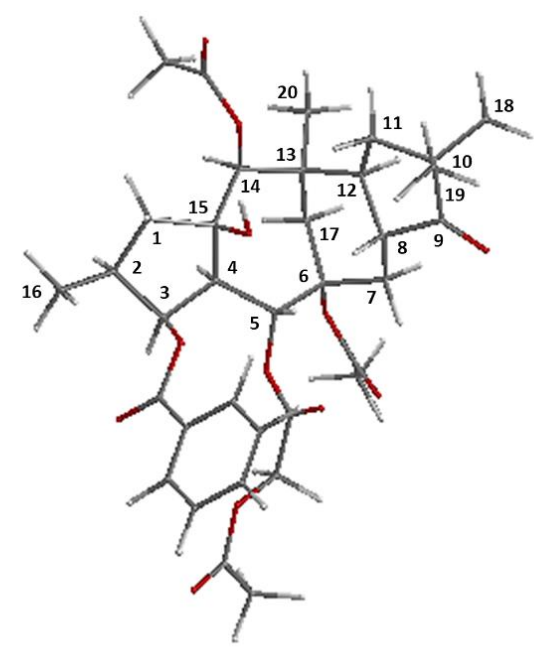

B

Figure 12. Panel A: Key 2D correlations of 12. Bold bonds indicate COSY interactions between nearby skeletal protons, while arrows $(\mathrm{C} \rightarrow \mathrm{H})$ highlight important $\mathrm{HMBC}$ cross-peaks.

Panel B: Calculated molecular structure of 12.

The relative configurations of the asymmetric carbons were elucidated by means of a NOESY experiment. $\mathrm{H}-4$ at the junction of rings was chosen as the initial $\alpha$ reference point. The cross-peaks of 
$\mathrm{H}-4$ with $\mathrm{H}-2$ and $\mathrm{H}-3$, and of the aromatic protons $\mathrm{H}-3^{\prime} / \mathrm{H}-7^{\prime}$ with $15-\mathrm{OH}$ showed the $\beta$-orientation of the $\mathrm{H}_{3}-16$ methyl and $\mathrm{C}-3$ benzoyl groups. A further correlation of $\mathrm{H}-4$ with $\mathrm{H}-17$ a indicated the $\alpha$-orientation of the $\mathrm{C}-17$ bridge. ${ }^{155}$ The NOE correlations of $\mathrm{H}-5$ with $\mathrm{H}-7 \beta, \mathrm{H}-8$, and $15-\mathrm{OH}$ led to the assignment of the $\mathrm{C}-5$ acetoxyacetyl unit as $\alpha$, while the $15-\mathrm{OH} / \mathrm{H}-1 \beta, \mathrm{H}-14 / \mathrm{H}-1 \alpha$, and $\mathrm{H}-14 / \mathrm{H}_{3}-20$ correlations confirmed that the C-14 acetyl moiety occupied a $\beta$-position. ${ }^{157}$ The large coupling constant between $\mathrm{H}-8$ and $\mathrm{H}-12\left({ }^{3} \mathrm{~J}_{\mathrm{H}-\mathrm{H}}=15.1 \mathrm{~Hz}\right)$ demonstrated their rigid antiperiplanar relationship. ${ }^{118}$ The C-11 geminal protons were readily distinguished by NOEs between $\mathrm{H}-11 \beta / \mathrm{H}_{3}-19, \mathrm{H}-11 \alpha / \mathrm{H}_{3}-18$, and $\mathrm{H}-12 / \mathrm{H}_{3}-18$. The above findings were in great agreement with a minimum energy conformation generated by molecular dinamics calculations using the MM2 force field method (Figure 12B).

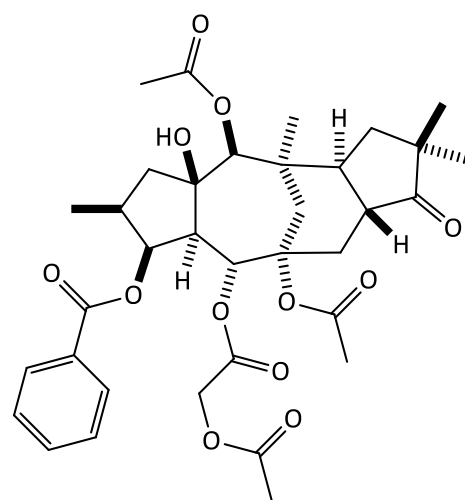

12

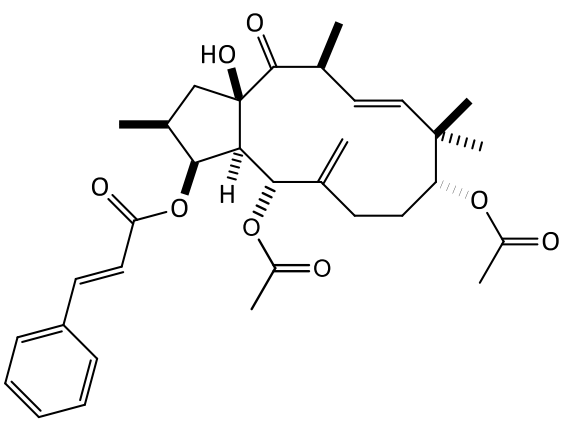

13

\section{ETA-6 (13)}

The molecular formula $\mathrm{C}_{33} \mathrm{H}_{42} \mathrm{O}_{8}$ of ETA-6 (13) was compatible with the HRESIMS ion at 589.2773 [ $\mathrm{M}+$ $\mathrm{Na}^{+}$(calcd 589.2777). Comparison of its 1D NMR data with those of the known jatrophane diterpenoid 15 (see later) revealed only minor differences between them, including the absent resonances of a cinnamoyl group, the presence of two acetyl singlets at $\delta_{\mathrm{H}} 2.05$ and 1.93, and the slightly downfield shifted H-9 ( $\delta_{\mathrm{H}} 4.36 \mathrm{~d}$ vs. $4.51 \mathrm{~d}$ in 15) (for comprehensive $1 \mathrm{D}$ NMR data of 13, see Annex 4). These observations, together with the HMBC cross-peaks of $\mathrm{H}-9$ and an acetyl methyl with a carbonyl carbon at $\delta_{C} \mathbf{1 7 0 . 9}$ suggested that compound $\mathbf{1 3}$ bears an acetyl function at C-9 instead of a cinnamate. The relative configuration was determined through NOE cross-peaks between $\mathrm{H}-2 / \mathrm{H}-3, \mathrm{H}-3 / \mathrm{H}-4, \mathrm{H}-4 / \mathrm{H}-13$, $\mathrm{H}-11 / \mathrm{H}-13, \mathrm{H}-5 / 15-\mathrm{OH}, \mathrm{H}-9 / \mathrm{H}-12, \mathrm{H}-9 / \mathrm{H}_{3}-19$, and $\mathrm{H}-12 / \mathrm{H}_{3}-20$. The NOE correlation of $\mathrm{H}-5$ with $\mathrm{H}-17 \mathrm{a}$ and the large ${ }^{3} \mathrm{H}_{\mathrm{H}-5}$ coupling constant $(10.1 \mathrm{~Hz})$ indicated that the exomethylene is perpendicular to the mean plane of the macrocycle, thus $\mathbf{1 3}$ favoured an endo-type conformation. ${ }^{83,188}$ 


\section{ETA-9 (14)}

The structure of ETA-9 (compound 14) was determined by 1D and 2D NMR spectroscopy, and it was found to be paralinone $A$, which is a known metabolite of E. segetalis and E. paralias. ${ }^{118,155}$

\section{ETA-5 (15)}

ETA-5 (15) was identified as 5-acetoxy-3,9-dicinnamoyloxy-15-hydroxy-14-oxojatropha-6(17),11Ediene, which was isolated from Euphorbia segetalis prior to our work. ${ }^{118}$

\section{ETA-1 (16), ETA-2 (17), and ETA-7 (18)}

The structures of ETA-1, ETA-2, and ETA-7 (16-18, respectively) were solved by 1D and 2D NMR measurements. Comparison of the proposed structures with literature data allowed the assignment of these diterpenoids as 3-O-angeloyl-20-deoxyingenol (16), ${ }^{189}$ 3-O-angeloyl-17-angeloyloxy-20deoxyingenol (17), ${ }^{156}$ and 20-O-acetyl-3-O-angeloyl-17-angeloyloxyingenol (18). ${ }^{118}$

\section{EGU-4 (19)}

The molecular formula $\mathrm{C}_{39} \mathrm{H}_{52} \mathrm{O}_{13}$ of $(\mathbf{1 9}$, guyonianin $\mathrm{G})$ was confirmed by the HRESIMS sodium adduct ion at $m / z 751.3338[\mathrm{M}+\mathrm{Na}]^{+}$(calcd 751.3306). According to the ${ }^{1} \mathrm{H}$ and JMOD spectra, the core of the molecule was pentaesterified with a benzoic acid $\left(\delta_{\mathrm{H}} 7.99 \mathrm{~d}, 7.57 \mathrm{t}, 7.42 \mathrm{t} ; \delta_{\mathrm{c}} 165.2,133.8,130.2,129.5\right.$, and 128.8), two acetic acids ( $\delta_{\mathrm{H}} 2.06 \mathrm{~s}, 2.03 \mathrm{~s} ; \delta_{\mathrm{C}} 170.4,169.4,21.4$, and 20.9), and two isobutyric acids $\left(\delta_{\mathrm{H}} 2.70 \mathrm{sept}, 2 \times 1.36 \mathrm{~d} ; \delta_{\mathrm{c}} 176.0,35.6,19.3,19.2\right.$, and $\delta_{\mathrm{H}} 1.84 \mathrm{sept}, 0.87 \mathrm{~d}, 0.51 \mathrm{~d} ; \delta_{\mathrm{c}} 175.1,33.7,19.1$, 17.7) (for comprehensive 1D NMR data of 19 and 20, see Annex 4). Not counting the esters, the 20 further signals displayed in the JMOD spectrum were categorized as four methyls, a methylene, an exo-methylene, seven methines (including five oxymethines), and two olefinic carbons. In addition, the five resonances of nonprotonated carbons were labelled as one keto $\left(\delta_{\mathrm{c}} 212.4\right)$, one olefinic $\left(\delta_{\mathrm{c}} 144.5\right)$, two oxygen-attached $\left(\delta_{c} 89.6\right.$ and 89.1$)$, and one quaternary $\left(\delta_{c} 41.7\right)$, respectively. The presence of two hydroxy groups in the molecule was shown by signals at $\delta_{H} 4.97$ and 4.43 with no HSQC correlations. The ${ }^{1} \mathrm{H}-{ }^{1} \mathrm{H}$ COSY spectrum defined a geminal proton pair $\left(\delta_{\mathrm{H}} 3.05 \mathrm{~d}, 2.10 \mathrm{~d}\right)[A]$, and three spin systems: $-\mathrm{CH}(\mathrm{OR})-\mathrm{CH}-\mathrm{CH}(\mathrm{OH})-\left(\delta_{\mathrm{H}} 5.75 \mathrm{~d}, 3.39 \mathrm{br} \mathrm{d}, 4.15 \mathrm{br} \mathrm{s}, 4.43 \mathrm{br} \mathrm{s}\right)[B],-\mathrm{CH}(\mathrm{OR})-\mathrm{CH}(\mathrm{OR})-$

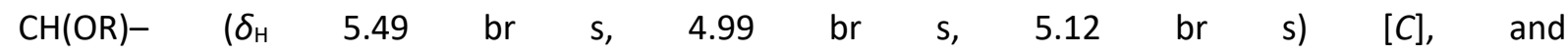
$-\mathrm{CH}=\mathrm{CH}-\mathrm{CH}\left(\mathrm{CH}_{3}\right)-\left(\delta_{\mathrm{H}} 6.04 \mathrm{~d}, 5.42 \mathrm{dd}, 3.86 \mathrm{dq}, 1.29 \mathrm{~d}\right)[D]$. The HMBC correlations $\mathrm{H}_{3}-16$ with $\mathrm{C}-1, \mathrm{C}-2$ $\left(\delta_{c} 89.1\right)$, and $\mathrm{C}-3$ connected subunits $A$ and $B$ together. The cross-peaks between $\mathrm{H}-1 \mathrm{~b}, \mathrm{H}-3,15-\mathrm{OH}$, and $C-15\left(\delta_{c} 89.6\right)$ suggested that $A$ and $B$ are incorporated into a cyclopentane ring. In order to satisfy the 14 degree of unsaturation indicated by the molecular formula, structural parts $B-D$ were 
assembled into a 12-membered macrocycle. Heteronuclear correlations of $\mathrm{H}-5,5-\mathrm{OH}, \mathrm{H}-7, \mathrm{H}-8$, and $\mathrm{H}-$ $17 \mathrm{a} / \mathrm{b}$ with $\mathrm{C}-6\left(\delta_{\mathrm{C}} 144.5\right)$, and of $\mathrm{H}-8, \mathrm{H}-9, \mathrm{H}-11, \mathrm{H}-12, \mathrm{H}_{3}-18$, and $\mathrm{H}_{3}-19$ with $\mathrm{C}-10\left(\delta_{\mathrm{C}} 41.7\right)$ established a jatrophane scaffold. The long-range correlations of $\mathrm{H}-1 \mathrm{a}, \mathrm{H}-13, \mathrm{H}_{3}-20$, and $15-\mathrm{OH}$ with the carbon at $\delta_{\mathrm{C}} 212.4$ required the keto group to be at $\mathrm{C}-14$. The diagnostic interactions of oxymethines $\mathrm{H}-3, \mathrm{H}-7$, $\mathrm{H}-8$, and $\mathrm{H}-9$ with respective ester carbonyls at $\delta_{\mathrm{c}} 169.4$ (acetyl), 175.1 (isobutyryl), 170.4 (acetyl), and 165.2 (benzoyl) determined the locations of the ester moieties. The second isobutyryl group could only be situated at $\mathrm{C}-2$, because no three-bond $\mathrm{HMBC}$ correlation was observed between its carbonyl atom $\left(\delta_{\mathrm{c}} 176.0\right)$ and protons of the terpenoid core. The hydrogens of 7-OiBu resonated in an upfield region than those of 2-OiBu $\left(\delta_{\mathrm{H}} 1.84\right.$ sept, $0.87 \mathrm{~d}, 0.51 \mathrm{~d}$, vs. 2.70 sept, $\left.2 \times 1.36 \mathrm{~d}\right)$, which was caused by the shielding effect of the C-9 benzoyl substituent. This phenomenon occurs when the ester group on C-7 is parallel with an aromatic functional group at C-9, and therefore its chemical shifts are heavily influenced by the aromatic ring current effect. ${ }^{190}$

The relative configuration of $\mathbf{1 9}$ was evaluated by a NOESY experiment. Concerning the NOEs between $\mathrm{H}-3 / \mathrm{H}-4, \mathrm{H}-4 / \mathrm{H}-5$, and $\mathrm{H}-4 / \mathrm{H}-7$, the $\mathrm{C}-3$ acetyl, $\mathrm{C}-5$ hydroxy, and $\mathrm{C}-7$ isobutyryl moieties were marked as $\beta$-oriented. From the NOE correlations between $5-\mathrm{OH} / \mathrm{H}_{3}-16,15-\mathrm{OH} / \mathrm{H}_{3}-16, \mathrm{H}-4 / \mathrm{H}-13, \mathrm{H}-1 \alpha / \mathrm{H}-13$, and $\mathrm{H}-5 / \mathrm{H}-8$, it was deduced that the methyls at $\mathrm{C}-2$ and $\mathrm{C}-13$, the $15-\mathrm{OH}$, and the 8-OAc groups occupy $\beta$-positions. A strong cross-peak from 5-OH to $\mathrm{H}-9$ disclosed the $\alpha$-position of the $\mathrm{C}-9$ benzoyl group. The geminal methyls $\mathrm{H}_{3}-18$ and $\mathrm{H}_{3}-19$ were distinguished via the $\mathrm{H}-11 / \mathrm{H}-13, \mathrm{H}-11 / \mathrm{H}_{3}-19, \mathrm{H}-12 / \mathrm{H}_{3}-20$, and $\mathrm{H}-12 / \mathrm{H}_{3}-18$ interactions. Interpretation of the coupling constants also offered valuable information regarding the conformation of the molecule. To start with, the $E$ stereochemistry of the $\Delta^{11,12}$ double bond was dictated by the large value of ${ }^{3} J_{\mathrm{H} 11-12}(15.8 \mathrm{~Hz})$. The small ${ }^{3} \mathrm{~J}_{\mathrm{H} 4-5}$ coupling constant (2.7 Hz), the NOE cross-peaks between $\mathrm{H}-4 / \mathrm{H}-7, \mathrm{H}-5 / \mathrm{H}-8$, together with the missing correlation of $\mathrm{H}-4$ with $\mathrm{H}-17$, revealed the exo-conformation of the diterpenoid. ${ }^{188,190}$

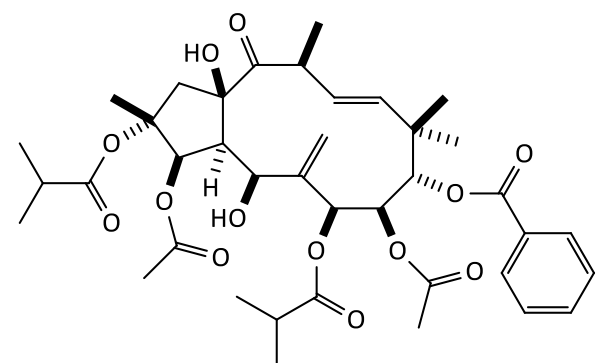

19

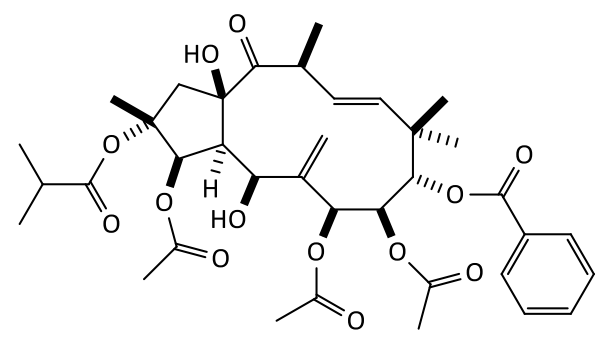

20 
EGU-3 (20)

The HRESIMS spectrum of (20, guyonianin $\mathbf{H}$ ) gave the molecular formula $\mathrm{C}_{37} \mathrm{H}_{48} \mathrm{O}_{13}$ via the sodiated adduct ion at $m / z 723.3022[\mathrm{M}+\mathrm{Na}]^{+}$(calcd 723.2993). The 1D NMR spectra displayed the signals of a benzoyl, an isobutyryl, and three acetyl groups besides the jatrophane skeleton. The absence of the upfield shifted protons of 7-OiBu indicated its replacement by an acetyl function. In a similar vein, the anisotropic effect of $9-\mathrm{OBz}$ was demonstrated by the strongly shielded nature of the 7-OAc methyl $\left(\delta_{\mathrm{H}}\right.$ 1.32 vs. $\delta_{\mathrm{H}} 2.03-3-\mathrm{OAc}$, and $\left.\delta_{\mathrm{H}} 2.05-8-\mathrm{OAc}\right)$.

EDI-17 (21), EDI-18 (22), and EDI-19 (23)

The ${ }^{1} \mathrm{H}$ and ${ }^{13} \mathrm{C}$ NMR data of compounds 21-23 were identical with those of kaempferol 3-Orhamnoside (21), ${ }^{191}$ quercetin 3-O-rhamnoside (22), ${ }^{192}$ and myricetin 3-O-rhamnoside (23), ${ }^{193}$ respectively.

\section{Discussion}

In the last few decades considerable attention has been devoted to the possible applications of spurge species and their metabolites in the treatment of human diseases. According to Vasas et al., the probability of finding new macrocyclic diterpenoids is very high (almost $70 \%$ of the isolated compounds are newly discovered). Until 2014 approximately 100 Euphorbia species had been subjected to phytochemical analysis. Although the number of the investigated species comprise only less than $5 \%$ of the plants belonging to the genus, spurges have already provided numerous compounds with valuable therapeutic properties. ${ }^{91}$ For example, ingenol 3-angelate is approved for the treatment of actinic keratosis, considered as the most common pre-cancerous skin lesion. Tigilanol tiglate (EBC-46), isolated from the Australian native plant Fontainea picrosperma (blushwood tree), has recently been approved for the therapy of advanced solid tumors of companion animals. Moreover, EBC-46 applied as intratumoral injection has demonstrated encouraging results in a human phase I clinical trial evaluating its safety, tolerability and preliminary efficacy. ${ }^{194}$ Resiniferatoxin is a macrocyclic diterpenoid possessing a highly potent agonist activity towards the transient vanilloid receptor 1 (TRPV1). In an ongoing phase I trial intrathecally administered reziniferatoxin is being evaluated for its ability to alleviate intractable pain associated with advanced cancer. ${ }^{195}$ Preliminary findings show that reziniferatoxin can selectively and irreversibly ablate nociceptive neurons, which could be used to control chronic pain. ${ }^{196}$ This diterpenoid is also investigated in a phase 3, randomized, multicentre, placebo-controlled study for its potential application in severe knee pain caused by osteoarthritis. ${ }^{197}$ These data demonstrate why Euphorbia diterpenoids represent a hot topic in pharmacognosy, definitely considered as natural compounds worthy of further investigations. 
Phytochemical investigations of E. dulcis, E. taurinensis, E. guyoniana, and E. davidii led to the isolation of 23 compounds. The structures of 20 diterpenoids, including 13 novel natural products, and 3 known flavonoid glycosides were established by NMR spectroscopy and HRESIMS measurements. Some of the isolated compounds exerted promising pharmacological (GIRK channel blocking, cytotoxic, and MDR modulating) activities.

\subsection{Isolation and purification of the diterpenoids and flavonoid glycosides}

Diterpenoids have previously been reported from various parts of Euphorbia species. Thus, the whole plants of E. dulcis and E. taurinensis, as well as all available aerial parts of E. guyoniana were processed in order to maximize the yields of compounds of interest. Structurally closely related diterpenoids display very similar chromatographic properties, hence their isolation is demanding and timeconsuming, and requires the application of multi-step chromatographic techniques. Since the diterpenoids are minor constituents of Euphorbia species, and only limited amounts of plant materials were accessible, the isolation procedures were carefully planned and performed under gentle conditions at neutral $\mathrm{pH}$. This way the chemical decomposition of diterpenoids (e.g. hydrolysis of the ester bonds in an acidic environment) was successfully prevented, which would otherwise result in the formation of misleading artefacts.

The fresh plant materials of $E$. dulcis and E. taurinensis were percolated with methanol at room temperature, while the dried sample of $E$. guyoniana was extracted with $\mathrm{CHCl}_{3}$ in an ultrasonic bath. Methanol is suitable for the extraction of a wide range of polar and apolar compounds because of its amphiphilic character. In the first step of separation, the diterpenoids of E. dulcis and E. taurinensis were enriched in $\mathrm{CHCl}_{3}$ by liquid-liquid partitioning. The concentrated crude extracts were chromatographed on polyamide columns with mixtures of $\mathrm{MeOH}-\mathrm{H}_{2} \mathrm{O}$. TLC analyses showed that the diterpenoids mostly accumulated in the fractions eluted with $60 \%$ and $80 \%$ aqueous $\mathrm{MeOH}$. Rough separations of the diterpenoid-rich eluates were performed by silica gel VLC, then the collected fractions were pooled according to similarities in their diterpenoid compositions. The initial fractionation of E. dulcis and E. taurinensis still resulted in complex mixtures of diterpenoids, therefore further VLC steps were carried out before using more selective chromatographic methods. The proper and complete separation of the individual compounds was achieved by PLC and HPLC.

In case of $E$. davidii, the $\mathrm{MeOH}$ extract was subjected to solvent-solvent extraction with $\mathrm{CHCl}_{3}$ and EtOAc. As the $\mathrm{CHCl}_{3}$-soluble fraction did not contain any compound worthy of an isolation attempt, the latter and more promising EtOAc phase was chosen for further separation. First, it was fractionated by VLC, then the flavonoid-rich subfractions were purified by PLC and HPLC. As a result of the isolation 
procedures, the plant materials yielded 20 diterpenoids (1-11 from E. dulcis, 12-18 from E. taurinensis, and 19 and 20 from E. guyoniana) and 3 flavonoid glycosides (21-23 from E. davidii).

\subsection{Structure elucidation of the isolated compounds}

The diterpenoids were isolated as white amorphous solids, and the flavonoids as yellow powders. The molecular formulas of diterpenoids were determined by means of HRESIMS measurements. The indices of hydrogen deficiency calculated from the molecular formulas were taken into account, because they provided valuable information on the number of rings and double bonds present in the molecules. The flavonoids were identified by comparison of their ${ }^{1} \mathrm{H}$ - and ${ }^{13} \mathrm{C} N M R$ data with literature values. The structures of diterpenoids were established by $1 \mathrm{D}$ and $2 \mathrm{D}$ NMR spectroscopy. The ${ }^{1} \mathrm{H}$, JMOD, ${ }^{1} \mathrm{H}-{ }^{1} \mathrm{H}$ COSY, HSQC, and HMBC spectra revealed the constitutions of terpenoid scaffolds, then the relative configurations of stereogenic carbons were deduced by relevant NOESY correlations. As a result of the NMR studies, complete ${ }^{1} \mathrm{H}$ - and ${ }^{13} \mathrm{C}$ NMR assignments were made for the new natural products. In addition, the absolute configuration of compound $\mathbf{1}$ was determined using single-crystal X-ray diffraction.

Fifteen of the isolated diterpenoids are based on jatrophane skeletons, while 3 were identified as ingenane, and 2 as segetane derivatives. Compounds $\mathbf{1 - 1 1}$ contain a $\Delta^{(5,6)}$ olefinic bond instead of the regular $\Delta^{(6,17)}$ double bond. The coupling constants between $\mathrm{H}-4$ and $\mathrm{H}-5(\sim 10 \mathrm{~Hz})$ are similar to the values previously reported for endo-conformers. Diagnostic NOE correlations of $\mathrm{H}-4$ with $\mathrm{H}_{3}-17$ further confirmed that these diterpenoids adopted an endo-type conformation. Compounds $\mathbf{1 3}$ and $\mathbf{1 5}$ were also determined as endo-conformers based on their large ${ }^{3} \int_{\mathrm{H} 4-5}$ coupling constants and indicative NOE interactions. Compounds 19 and $\mathbf{2 0}$ strongly prefer exo-conformations, corroborated by the small ${ }^{3} \mathrm{H}_{\mathrm{H}-}$ ${ }_{5}$ coupling constants $(\sim 3 \mathrm{~Hz})$, and by the results of the NOESY experiments.

Compounds 1-20 are highly esterified with acetyl, benzoyl, tigloyl, angeloyl, isobutyryl, cinnamoyl, and acetoacetyl groups (see Annexes $\mathbf{5}$ and $\mathbf{6}$ ). The diterpenoids of $E$. dulcis differ only in their esterification patterns at C-7, C-8, C-9, C-14, and C-15, while at C-3 they contain a conserved benzoyl moiety. Tigloyl groups were found exclusively on C-7 and C-14. Compound 9, a structural isomer of euphomelliferene B, has C-14 hydroxy and C-15 acetyl functions. To date only a few jatrophanes have been reported with the same arrangement of substituents. ${ }^{124,187}$ The EUD-series is stereochemically homogeneous, characterized by a trans-fused ring system, $2 \beta$ - and $13 \beta$-methyls, and $7 \beta, 8 \beta, 9 \alpha, 14 \beta$, and $15 \beta$ acyl or hydroxy functions. Compounds $\mathbf{1}$ and $\mathbf{1 1}$ are not substituted at C-8. The new jatrophane diterpenoid 13 has an $\alpha$-acetyl group at C-9, while a structurally related diterpenoid from $E$. segetalis possesses a C-9 $\beta$-cinnamoyl group. Compounds 19 and 20 bear isobutyryl and acetyl functions at C-7 and, similarly to other jatrophanes reported from E. guyoniana, are esterified at C-2. 
Segetanes represent a special class of diterpenoids: only 12 compounds had been isolated from E. segetalis, E. paralias, E. portlandica, and E. peplus prior to our work. Unlike the majority of segetanes, compound 12 bears a $\beta$-oriented acyl group at $C-14$, and the $C-17$ bridge is not substituted. Compounds $\mathbf{1 6 - 1 8}$ are known derivatives of ingenol.

\subsection{Chemotaxonomical aspects}

Macrocyclic diterpenoids are considered to be important taxonomic biomarkers because of their structural diversity and limited distribution in the plant kingdom. E. dulcis afforded a series of jatrophane diterpenoids bearing a $\Delta^{(5,6)}$ olefinic bond instead of the more frequent $6(17)$-exomethylene group. In fact, this structural feature has only been found in a minority of jatrophanes and, interestingly, most of those diterpenoids were isolated from spurge species of section Helioscopia of subgenus Esula, ${ }^{41}$ namely from E. helioscopia, ${ }^{114,132,151,187,198}$ E. mellifera, ${ }^{185}$ E. platyphyllos, ${ }^{29}$ E. gaditana, ${ }^{129}$ E. pubescens (syn. E. hirsuta), ${ }^{123,199}$ E. squamosa, ${ }^{136}$ E. stricta (syn. E. serrulata) ${ }^{24}$ and from E. dulcis in our study. Similar jatrophanes bearing a 6(17)-exomethylene moiety were reported from other sections as well (E. maddenii - sect. Arvales, ${ }^{200}$ E. lunulata - sect. Esula, ${ }^{186}$ and E. characias - sect. Patellares), ${ }^{75}$ and from one species of subgenus Euphorbia (Pedilanthus tithymaliodes, ${ }^{124,147}$ syn. $E$. tithymaloides - sect. Crepidaria). ${ }^{7}$ As the above data show, subgenus Esula of the genus Euphorbia is particularly rich in jatrophanes with a $\Delta^{(5,6)}$ double bond, thus the presence of such compounds might be a useful chemotaxonomic marker for the characterization of members of this subgenus.

Segetanes represent a unique group of diterpenoids with noteworthy chemotaxonomical aspects. According to an earlier classification, E. taurinensis and E. peplus were considered to be members of section Cymatospermum (Prokh.) Prokh., while E. segetalis, E. paralias, and E. portlandica belonged to the section Paralias Dumort. ${ }^{201}$ New phylogenetic studies suggest that E. taurinensis, E. segetalis, E. paralias, and E. portlandica belong to section Paralias. ${ }^{41,96}$ Our finding that E. taurinensis produces segetanes and no pepluanes strongly supports the new taxonomic classification of $E$. taurinensis. The close intra-generic relationships between E. taurinensis, E. segetalis, and E. paralias have also been demonstrated by similarities in their diterpenoid compositions: compounds 14, 16, and 17 have earlier been identified in both E. segetalis and E. paralias, ${ }^{118,155,156}$ while compounds $\mathbf{1 5}$ and $\mathbf{1 8}$ were described from E. segetalis. ${ }^{118}$

Regarding E. guyoniana, it is the only representative of section Guyonianae in subgenus Esula. ${ }^{41}$ Besides ent-abietane and atisane diterpenoids, numerous jatrophanes have been described from the plant. In previous studies plant materials of Algerian origin were investigated, while we have received the plant sample from Tunisia. The two isolated compounds (19 and 20) are not identical with any of the previously reported jatrophanes, which indicates the high chemical diversity of this species. 
The latest classification suggests that $E$. davidii belongs to section Poinsettia of subgenus Chamaesyce. ${ }^{42}$ Diterpenoids have only been detected in species of section Anisophyllum, and this fact could provide a reasonable explanation to why we failed to obtain any diterpenoids from E. davidii in spite of our best efforts. ${ }^{96}$ The chemical constituents of $E$. taurinensis and E. davidii have not been investigated previously. Furthermore, all of the isolated diterpenoids and flavonoid glycosides are described for the first time in the investigated plants.

\subsection{Bioactivity of the isolated compounds and plant extracts}

Pharmacological investigations were performed in cooperation with Rytmion Ltd. (Szeged, Hungary) ion channel blocking activity of the diterpenoids; the Department of Medical Microbiology and Immunobiology (University of Szeged, Szeged, Hungary) - MDR-reversing and cytotoxic activities of diterpenoids; and the Department of Pharmacodynamics and Biopharmacy (University of Szeged, Szeged, Hungary) - antiproliferative activity of plant extracts.

\subsubsection{Ion channel blocking activity of the diterpenoids}

Diterpenoids are characteristic secondary metabolites of the Euphorbia species, however, limited data are available on their cardiac effects. GIRK channels are involved in the fine electrical regulation of neurons, $\beta$-pancreatic cells, and atrial myocytes. It is suspected that malfunctions of GIRK channels contribute to the development of neuropathic pain, drug addiction, and cardiac arrhythmias. By prolonging atrial effective refractory period, the selective blockade of GIRK proteins appears to be a promising approach in searching for novel antiarrhythmic agents. ${ }^{202,203}$ hERG channels, frequently referred to as Kv 11.1, pass the rapid component of delayed rectifier $\mathrm{K}^{+}$current, and thus influence the duration of the plateau phase, as well as the pacemaking activity of sinoatrial and atrioventricular node cells. ${ }^{204}$ The inhibition of hERG channels significantly elongates the QT interval on the electrocardiogram, which predisposes patients to life-threatening Torsades de Pointes (TdP) arrhythmias and, even worse, to sudden cardiac death. Plenty of structurally unrelated (e.g. psychiatric, antihistamine, antimicrobial, and antiarrhythmic) drugs have been reported to exhibit a strong affinity for the hERG channels. ${ }^{205}$ Due to the clinical importance of the proarrhythmogenic potential of commonly used pharmaceuticals, screening drug candidates for their hERG channel selectivity during preclinical safety assessments is a common practice nowadays. ${ }^{206}$

Because of the serious disadvantages of current antiarrhythmic drugs (e.g. poor efficacy rate, lack of atrial specificity associated with an increased risk of side effects), many research efforts have been made to discover novel natural compounds with more selective effects on atrial ion channels. Vasas et al. reported that myrsinane, premyrsinane, and cyclomyrsinane diterpenoids isolated from E. falcata 
exert a selective GIRK blocking activity, ${ }^{207}$ and this finding served as a motivation to explore the electrophysiological effects of the isolated diterpenoids. Compounds 1-12 and 15-20 were investigated on a stable transfected HEK-GIRK1/4 (Kir3.1/3.4) cell line using an automated patch-clamp equipment (the methodology of GIRK and hERG assays is available in detail in the corresponding paper published by Vasas et al.). The majority of the tested compounds were found to exert a significant inhibitory effect on the GIRK proteins at $10 \mu \mathrm{m}$, and some of them displayed a notable blocking activity even at $1 \mu$ m concentrations (Table 1).

Table 1. Electrophysiological effects of compounds 1-12 and 15-20 on GIRK current in HEK-GIRK cells.

\begin{tabular}{|c|c|c|c|}
\hline \multirow[b]{3}{*}{ Compound } & \multicolumn{3}{|c|}{ GIRK inhibition" (\%) } \\
\hline & \multicolumn{2}{|c|}{ Concentrations of the applied diterpenoids } & \multirow{2}{*}{$\begin{array}{c}\text { Propafenone* } \\
1 \mu \mathrm{M}\end{array}$} \\
\hline & $1 \mu \mathrm{M}$ & $10 \mu \mathrm{M}$ & \\
\hline 1 & $35.5 \pm 5.6$ & $88.7 \pm 2.4$ & $93.2 \pm 1.7$ \\
\hline 2 & $38.5 \pm 3.5$ & $85.0 \pm 0.8$ & $92.6 \pm 3.2$ \\
\hline 3 & $23.5 \pm 0.3$ & $35.7 \pm 7.4$ & $70.1 \pm 5.9$ \\
\hline 4 & $15.3 \pm 2.7$ & $60.8 \pm 6.8$ & $60.6 \pm 2.6$ \\
\hline 5 & $16.8 \pm 2.1$ & $66.6 \pm 3.5$ & $64.2 \pm 2.5$ \\
\hline 6 & $16.0 \pm 10.2$ & $26.8 \pm 6.9$ & $65.2 \pm 3.4$ \\
\hline 7 & $11.2 \pm 6.3$ & $23.5 \pm 3.3$ & $72.7 \pm 1.5$ \\
\hline 8 & $15.7 \pm 9.0$ & $25.7 \pm 1.7$ & $69.4 \pm 3.0$ \\
\hline 9 & $27.2 \pm 4.8$ & $66.0 \pm 8.2$ & $76.3 \pm 6.7$ \\
\hline 10 & $33.8 \pm 4.9$ & $83.4 \pm 0.6$ & $94.2 \pm 2.4$ \\
\hline 11 & $31.1 \pm 1.9$ & $78.7 \pm 6.1$ & $74.7 \pm 6.2$ \\
\hline 12 & $17.7 \pm 1.3$ & $28.6 \pm 2.8$ & $68.0 \pm 5.0$ \\
\hline 15 & $22.2 \pm 5.8$ & $23.7 \pm 8.1$ & $61.2 \pm 2.5$ \\
\hline 16 & $23.8 \pm 11.4$ & $52.3 \pm 5.4$ & $75.8 \pm 2.5$ \\
\hline 17 & $43.9 \pm 13.8$ & $80.4 \pm 0.3$ & $83.8 \pm 1.4$ \\
\hline 18 & $16.4 \pm 4.3$ & $45.1 \pm 5.4$ & $70.6 \pm 1.2$ \\
\hline 19 & $19.2 \pm 1.4$ & $70.4 \pm 4.2$ & $73.1 \pm 4.1$ \\
\hline 20 & $20.3 \pm 8.1$ & $48.4 \pm 4.3$ & $58.1 \pm 3.0$ \\
\hline
\end{tabular}

The $\mathrm{IC}_{50}$ values were calculated from the dose-response curves (Appendix I). Compounds $\mathbf{1}$ and $\mathbf{1 7}$ were the most effective diterpenoids, with $\mathrm{IC}_{50}$ values of $1.3 \pm 0.2$ and $1.5 \pm 0.1 \mu \mathrm{M}$, respectively. The $\mathrm{IC}_{50}$ values of compounds $\mathbf{2}$ and $\mathbf{1 0}$ were similar $\left(1.6 \pm 0.2\right.$ and $1.7 \pm 0.2 \mu \mathrm{M}$, respectively). The $\mathrm{IC}_{50}$ values were determined as $2.6 \pm 0.5 \mu \mathrm{M}$ for compound $11,3.4 \pm 0.1 \mu \mathrm{M}$ for compound 9 , and $12.2 \pm 0.5 \mu \mathrm{M}$ for compound 16. These jatrophane and ingenane diterpenoids were tested for their hERG-related cardiotoxicity on HEK-hERG (Kv11.1) cells. The presented data demonstrate that none of the jatrophanes interfered with the function of the hERG proteins, however, the outward $\mathrm{K}^{+}$flow was strongly hampered by compound $\mathbf{1 7}$ (Table 2). 
Table 2. hERG inhibitory effects of the selected diterpenoids.

\begin{tabular}{|c|c|c|c|}
\hline & \multicolumn{3}{|c|}{ hERG inhibition ${ }^{*}(\%)$} \\
\hline Compound & $1 \mu \mathrm{M}$ & $10 \mu \mathrm{M}$ & Amitriptyline* \\
\hline $\mathbf{1}$ & $10.8 \pm 5.7$ & $24.9 \pm 6.4$ & $10 \mu \mathrm{M}$ \\
\hline $\mathbf{2}$ & $6.5 \pm 5.2$ & $24.4 \pm 2.0$ & $97.7 \pm 0.8$ \\
\hline $\mathbf{9}$ & $11.2 \pm 0.6$ & $22.7 \pm 2.6$ & $99.1 \pm 0.9$ \\
\hline $\mathbf{1 0}$ & $13.2 \pm 2.2$ & $24.0 \pm 1.8$ & $99.3 \pm 0.7$ \\
\hline $\mathbf{1 1}$ & $3.3 \pm 1.5$ & $19.0 \pm 0.5$ & $98.1 \pm 0.5$ \\
\hline $\mathbf{1 6}$ & $1.8 \pm 0.4$ & $7.9 \pm 1.0$ & $99.3 \pm 0.7$ \\
\hline $\mathbf{1 7}$ & $11.2 \pm 0.1$ & $55.4 \pm 0.4$ & $99.2 \pm 0.8$ \\
\hline & \#Results are means \pm SEM, $n=2-3 ; *$ : positive control \\
\hline
\end{tabular}

Our investigations focusing on the GIRK channels showed no clear correlations between the inhibitory effect and the substitution patterns, so unfortunately, we could not establish any structure-activity relationships for the EUD-series. Nevertheless, jatrophane and ingenane diterpenoids were proven to be potent inhibitors of the atrial GIRK proteins. In case of the hERG experiment, a substantial difference was found between the effectiveness of compounds 16 and 17; the latter ingenane contains an angeloyl group at C-17, which might influence the affinity of that compound towards the hERG channels, although this piece of data is not enough to draw firm conclusions. Further investigations are required to obtain a deeper insight into how the structural characteristics of Euphorbia diterpenoids affect their interactions with the pharmacologically important GIRK and hERG channels.

\subsubsection{MDR-reversing and cytotoxic activities of diterpenoids isolated from $E$. taurinensis}

The development of multidrug resistance is a principal reason behind the failure of chemotherapy. The MDR phenotype is associated with the overexpression of ATP-binding casette $(A B C)$ transporters, including P-glycoprotein (P-gp/ABCB1), multidrug resistance protein (MRP1/ABCC1) and breast cancer resistance protein (BCRP/ABCG2). These membrane-associated efflux proteins are able to recognize and extrude numerous structurally unrelated anticancer drugs. Possible ways of overcoming MDR have been extensively investigated, but no breakthroughs have been achieved until today.

Euphorbia diterpenoids are best known for their strong MDR-reversing activities. Therefore, we examined the P-gp modulating and cytotoxic properties of compounds $\mathbf{1 2}$ and 15-18 on an L5178 mouse lymphoma cell line using rhodamine 123 accumulation and MTT cell viability assays (Appendix II). Retention of rhodamine 123 was measured by flow cytometry, and the fluorescence activity ratio (FAR) was calculated using the following equation: $F A R=\frac{F I_{M D R} \text { treated } / F I_{M D R} \text { control }}{F I_{P A R} \text { treated } / F I_{P A R} \text { control }}$. Fl represents the fluorescence intensities observed for MDR1 gene-transfected and drug-sensitive parent cell lines in 
the presence (treated) and absence (control) of the analyte. Compared to the positive control verapamil, all of the compounds were found to inhibit the P-gp efflux pump on the resistant mouse Tlymphoma cells (Figure 13). Compounds 12, 17, and 18 were shown to be the most powerful modulators at a concentration of $20 \mu \mathrm{M}$, with an efficacy of 7-9-fold higher compared to verapamil (FAR: 44.44, 59.36, and 56.16, respectively).

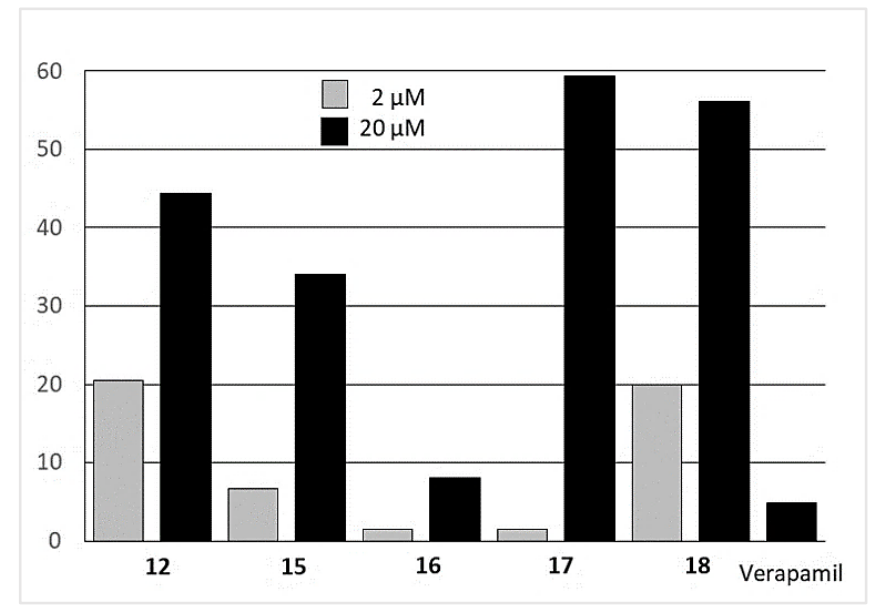

Figure 13. Efflux pump modulating activities of the tested diterpenoids.

Cell growth was determined by measuring the optical density at $550 \mathrm{~nm}$ with a multiscan EX ELISA reader. The results of the MTT assay are summarized in Table 3. Based on our findings, neither the segetane, nor the jatrophane diterpenoids tested exert any cytotoxic activity on the sensitive parent and on the resistant MDR cells. In contrast, the ingenane diterpenoids $\mathbf{1 7}$ and $\mathbf{1 8}$ displayed a cytotoxic effect on both cell lines. The $\mathrm{IC}_{50}$ values of the most active compound $\mathbf{1 7}$ on the two cell lines were almost equal, indicating that it has no selectivity towards the resistant cell line, while compound $\mathbf{1 8}$ was more potent on the resistant cell line. The presence of a larger ester function at C-17 might enhance the cytotoxicity of the ingenanes, however, further data are needed to confirm this speculation. 
Table 3. Cytotoxic activities of compounds $\mathbf{1 2}$ and 15-18 on parent and MDR mouse T-lymphoma cells.

\begin{tabular}{|c|c|c|c|c|}
\hline & \multicolumn{2}{|c|}{ Parent mouse T-Iymphoma cell line } & \multicolumn{2}{|c|}{ MDR mouse T-lymphoma cell line } \\
\hline Compound & $\mathrm{IC}_{50}(\mu \mathrm{M})$ & $\mathrm{Cl}^{\#}$ & $\mathrm{IC}_{50}(\mu \mathrm{M})$ & $95 \% \mathrm{Cl}$ \\
\hline 12 & $>100$ & - & $>100$ & - \\
\hline 15 & $>100$ & - & $>100$ & - \\
\hline 16 & $>100$ & - & $>100$ & - \\
\hline 17 & 53.35 & $51.34-55.36$ & 59.83 & $58.25-61.41$ \\
\hline 18 & 82.47 & $80.38-84.56$ & 62.81 & $61.65-63.97$ \\
\hline Doxorubicin* & 0.7 & $0.42-0.98$ & 2.14 & $1.76-2.52$ \\
\hline
\end{tabular}

\#: $95 \%$ confidence interval, $n=3 ; *$ : positive control

\subsubsection{Antiproliferative activities of the extracts of $E$. davidii}

The prepared extracts ( $n$-hexane, $\mathrm{CHCl}_{3}$, EtOAc, $50 \% \mathrm{MeOH}$ residue, $\mathrm{H}_{2} \mathrm{O}$ ) were screened in vitro for their antiproliferative activity against HeLa (cervix epithelial adenocarcinoma), MCF7 (breast epithelial adenocarcinoma), A2780 (ovarian carcinoma), and A431 (skin epidermoid carcinoma) cell lines using the MTT assay (Table 4). Cisplatin was applied as a reference compound. ${ }^{208}$ The $n$-hexane and $\mathrm{CHCl}_{3}$ extracts were found to exhibit a dose-dependent cell growth inhibitory activity on all cell lines. The flavonoid-rich EtOAc fraction did not inhibit the proliferation of any cancer cell lines.

Table 4. Antiproliferative effects of the prepared extracts against selected cancer cell lines.

\begin{tabular}{|c|c|c|c|c|c|}
\hline \multirow{2}{*}{ Extracts } & \multirow{2}{*}{$\begin{array}{l}\text { Concentration. } \\
(\mu \mathrm{g} / \mathrm{mL})\end{array}$} & \multicolumn{4}{|c|}{ Inhibition of cell growth ${ }^{\#}(\%)$} \\
\hline & & Hela & MCF7 & A2780 & A431 \\
\hline \multirow{2}{*}{$n$-Hexane } & 10 & $14.6 \pm 1.8$ & $33.1 \pm 2.0$ & $19.4 \pm 1.4$ & $18.1 \pm 0.8$ \\
\hline & 30 & $22.4 \pm 2.7$ & $45.9 \pm 1.6$ & $26.7 \pm 0.9$ & $25.7 \pm 3.0$ \\
\hline \multirow{2}{*}{ Chloroform } & 10 & $-*$ & $30.8 \pm 2.2$ & $21.8 \pm 0.7$ & - \\
\hline & 30 & $22.3 \pm 2.7$ & $52.6 \pm 0.9$ & $47.1 \pm 0.7$ & $21.6 \pm 0.4$ \\
\hline \multirow{2}{*}{ Ethyl acetate } & 10 & - & - & - & - \\
\hline & 30 & - & - & - & - \\
\hline \multirow{2}{*}{ 50\% Methanol } & 10 & - & - & - & - \\
\hline & 30 & - & $15.8 \pm 2.3$ & - & - \\
\hline \multirow{2}{*}{ Water } & 10 & - & - & - & - \\
\hline & 30 & - & $27.9 \pm 1.9$ & $15.2 \pm 0.8$ & - \\
\hline \multirow{2}{*}{ Cisplatin } & 10 & $42.6 \pm 2.3$ & $66.9 \pm 1.8$ & $83.6 \pm 1.2$ & $88.5 \pm 0.5$ \\
\hline & 30 & $99.9 \pm 0.3$ & $96.8 \pm 0.4$ & $95.0 \pm 0.3$ & $90.2 \pm 1.8$ \\
\hline
\end{tabular}

\#: Results are mean \pm SEM, $n=5$; : Extracts displaying less than $10 \%$ inhibition of cancer cell proliferation were regarded as ineffective, and therefore the values are omitted. 


\section{Summary}

The present work covered the phytochemical analysis of four spurge species, namely E. dulcis, E. taurinensis, E. guyoniana, and E. davidii, the isolation and structure determination of their diterpenoids and flavonoids, and the pharmacological investigations of extracts and compounds of these species. The isolation and purification procedures were carried out by multi-step chromatographic techniques, involving polyamide OCC, VLC, PLC, and HPLC on NP and RP silica gel. The structures of the isolated compounds were elucidated by means of HRESIMS, $1 D\left({ }^{1} \mathrm{H}, J M O D\right)$ and $2 \mathrm{D}$ (HSQC, HMBC, ${ }^{1} \mathrm{H}-{ }^{1} \mathrm{H}$ COSY, NOESY) NMR experiments. Interpretation of the spectral data allowed the complete and unambiguous ${ }^{1} \mathrm{H}$ - and ${ }^{13} \mathrm{C}$ assignments of the novel diterpenoids. In addition, the absolute configuration of compound $\mathbf{1}$ was determined by single-crystal X-ray diffraction.

The $\mathrm{MeOH}$ extract of $E$. dulcis yielded nine novel (1-9) and two known (10 and 11) jatrophane diterpenoids. The diterpenoids possess a $\Delta^{(5,6)}$ double bond, and are highly esterified with benzoic-, tiglic-, and acetic acids. Moreover, compound $\mathbf{9}$ was found to be an interesting structural isomer of euphomelliferene B. The compounds isolated from E. dulcis represent a stereochemically homogeneous series of diterpenoids with different substitution patterns. The diterpenoids were found to adopt endo-type conformations, as dictated by diagnostic coupling constant values and NOESY cross-peaks. The chemical composition of $E$. dulcis revealed its close relationship with other members of section Helioscopia of subgenus Esula.

The $\mathrm{MeOH}$ extract of E. taurinensis afforded seven diterpenoids with various parent skeletons, including a novel and a known segetane (12 and 14, respectively), a novel and a known jatrophane (13 and 15, respectively), and 3 known ingenanes (16-18). Unlike most of the previously described segetanes, compound 12 contains a $\beta$-oriented acetyl group at C-14 and is not substituted at C-17. Compounds 13 and 15 preferentially adopt endo-type conformations, and only differ in the esterification and relative configuration of C-9. The presence of segetane diterpenoids in E. taurinensis supports the latest chemotaxonomic classification of this spurge species.

As a result of our research, 2 novel jatrophane diterpenoids (19 and 20) were isolated from the $\mathrm{MeOH}$ extract of E. guyoniana. The polyhydroxylated cores of the molecules are esterified with benzoyl-, acetyl-, and isobutyryl groups. The exo-conformation of the diterpenoids was apparent from their NMR spectral properties. Ent-abietanes and jatrophanes are characteristic secondary metabolites of the plant, however, compounds $\mathbf{1 9}$ and $\mathbf{2 0}$ are not identical with previously reported diterpenoids. This finding suggests a great variation in the diterpenoid compositions of populations of $E$. guyoniana grown at different geographical locations.

The EtOAc phase of the $\mathrm{MeOH}$ extract of $E$. davidii yielded 3 ubiquitous flavonoid glycosides (the 3-Orhamnosides of kaempferol, quercetin, and myricetin), however, we failed to obtain any diterpenoids 
from the plant material. The absence of diterpenoids in this invasive weed is not surprising in the light of literature data; the sporadic occurrence of diterpenoids in subgenus Chamaesyce have only been described in members of section Anisophyllum, while E. davidii belongs to section Poinsettia.

The biological activities of the isolated diterpenoids and some of the plant extracts were investigated in collaboration with of our cooperative partners. Compounds 1-12 and 15-20 were studied on a stable transfected HEK-GIRK1/4 cell line, and the effect of diterpenoids on inward $\mathrm{K}^{+}$currents was measured by an automated patch-clamp equipment. Compounds $1, \mathbf{2}, \mathbf{9}, \mathbf{1 0}, \mathbf{1 1}, \mathbf{1 6}$, and $\mathbf{1 7}$, exerting the most pronounced inhibitory effects, were tested on HEK-hERG cells. The results demonstrated that while jatrophanes are potent blockers of the atrial GIRK channels, their interactions with hERG proteins are negligible. Significant inhibition of the hERG channels was only observed for compound 17 . To the best of our knowledge, our group is the first one to evaluate the electrophysiological effects of jatrophanes, segetanes, and ingenanes on GIRK and hERG proteins. Considering the selective activities of jatrophanes, they may represent a group of potential lead compounds for the development of novel therapeutic agents against atrial fibrillation. Diterpenoids of different skeletons isolated from $E$. taurinensis exerted notable MDR-reversing activities in an L5178 mouse lymphoma cell line. The novel segetane compound (12), as well as two ingenanes (17 and $\mathbf{1 8})$ were shown to be the most powerful among the tested diterpenoids, reaching an efficacy of 7-9-fold higher compared to the positive control verapamil. The ingenanes 17 and 18 were cytotoxic, while the segetanes and jatrophanes were ineffective in the cytotoxicity assay. Furthermore, the $n$-hexane and $\mathrm{CHCl}_{3}$ extracts of $E$. davidii exhibited a weak to moderate, dose-dependent cell growth inhibitory activity on four carcinoma cell lines. 


\section{References}

${ }^{1}$ Mwine JT, Van Damme P. J. Med. Plants. Res. 2011, 5: 652-662.

${ }^{2}$ Frodin DG. Taxon 2004, 53: 753-776.

${ }^{3}$ Király G. Új magyar füvészkönyv, Jósvafő: Aggteleki Nemzeti Park Igazgatóság, 2009, pp. 268-272.

${ }^{4}$ Barina Z, Shevera M, Sîrbu C, Pinke G. Cent. Eur. J. Biol. 2013, 8: 87-95.

${ }^{5}$ Wolf M, Király G. Acta Bot. Hung. 2014, 56: 243-250.

${ }^{6}$ Bátori Z, Erdős L, Somlyay L. Acta Bot. Hung. 2012, 54: 235-243.

${ }^{7}$ Dorsey BL, Haevermans T, Aubriot X, Morawetz JJ, Riina R, Steinmann VW, Berry PE. Taxon 2013, 62: $291-315$.

${ }^{8}$ Pintus F, Medda R, Rinaldi AC, Spanò D, Floris G. Plant Biosyst. 2010, 144: 381-391.

${ }^{9}$ Mangold JM, Fuller KB, Davis SC, Rinella MJ. Invasive Plant Sci. Manag. 2018, 11: 96-100.

${ }^{10}$ Appendino G, Szallasi A. Life Sci. 1997, 60: 681-696.

${ }^{11}$ Webster GL. Clin. Dermatol. 1986, 4: 36-45.

${ }^{12}$ Ernst M, Grace OM, Saslis-Lagoudakis CH, Nilsson N, Simonsen HT, Rønsted N. J. Ethnopharmacol. 2015, 176: 90-101.

${ }^{13}$ Liang QL, Dai CC, Jiang JH, Tang YP, Duan JA. Fitoterapia 2009, 80: 514-516.

${ }^{14}$ Huang L, Chen S, Yang M. J. Med. Plants Res. 2012, 6: 5176-5185.

${ }^{15}$ Liang X, Liu ZG, Cao YF, Meng DL, Hua HM. Biochem. Syst. Ecol. 2014, 57: 345-349.

${ }^{16}$ Schultes RE. Bot. J. Linn. Soc. 1987, 94: 79-95.

${ }^{17}$ Hohmann J, Vasas A, Günther G, Máthé I, Evanics F, Dombi G, Jerkovich G. J. Nat. Prod. 1997, 60: 331-335.

${ }^{18}$ Günther G, Hohmann J, Vasas A, Máthé I, Dombi G, Jerkovich G. Phytochemistry 1998, 47: 1309-1313.

${ }^{19}$ Hohmann J, Günther G, Vasas A, Kálmán A, Argay G. J. Nat. Prod. 1999, 62: 107-109.

${ }^{20}$ Hohmann J, Evanics F, Vasas A, Dombi G, Jerkovich G, Máthé I. J. Nat. Prod. 1999, 62: 176-178.

${ }^{21}$ Hohmann J, Vasas A, Günther G, Dombi G, Blazsó G, Falkay Gy, Máthé I, Jerkovich Gy. Phytochemistry 1999, 51: 673-677.

22 Hohmann J, Evanics F, Berta L, Bartók T. Planta Med. 2000, 66: 291-294.

${ }^{23}$ Hohmann J, Rédei D, Evanics F, Kálmán A, Argay G, Bartók T. Tetrahedron 2000, 56: 3619-3623.

${ }^{24}$ Hohmann J, Molnár J, Rédei D, Evanics F, Forgó P, Kálmán A, Argay G, Szabó P. J. Med. Chem. 2002, 45: $2425-$ 2431.

${ }^{25}$ Hohmann J, Evanics F, Dombi G, Molnár J, Szabó P. Tetrahedron 2001, 57: 211-215.

${ }^{26}$ Hohmann J, Evanics F, Dombi G, Szabó P. Tetrahedron Lett. 2001, 42: 6581-6584.

${ }^{27}$ Hohmann J, Rédei D, Forgó P, Molnár J, Dombi G, Zorig T. J. Nat. Prod. 2003, 66: 976-979.

${ }^{28}$ Rédei D, Hohmann J, Evanics F, Forgó P, Szabó P, Máthé I. Helv. Chim. Acta 2003, 86: 280-289.

${ }^{29}$ Hohmann J, Forgó P, Csupor D, Schlosser G. Helv. Chim. Acta 2003, 86: 3386-3393.

${ }^{30}$ Vasas A, Hohmann J, Forgó P, Szabó P. Tetrahedron 2004, 60: 5025-5030.

${ }^{31}$ Sulyok E, Vasas A, Rédei D, Dombi G, Hohmann J. Tetrahedron 2009, 65: 4013-4016.

${ }^{32}$ Vasas A, Sulyok E, Rédei D, Forgó P, Szabó P, Zupkó I, Berényi Á, Molnár J, Hohmann J. J. Nat. Prod. 2011, 74: 1453-1461.

${ }^{33}$ Forgó P, Rédei D, Hajdú Zs, Szabó P, Szabó L, Hohmann J. J. Nat. Prod. 2011, 74: 639-643.

${ }^{34}$ Sulyok E, Vasas A, Rédei D, Forgó P, Kele Z, Pinke G, Hohmann J. Tetrahedron 2011, 67: 7289-7293.

${ }^{35}$ Vasas A, Sulyok E, Martins A, Rédei D, Forgó P, Kele Z, Zupkó I, Molnár J, Pinke G, Hohmann J. Tetrahedron 2012, 68: 1280-1285.

${ }^{36}$ Rédei D, Forgó P, Molnár J, Szabó P, Zorig T, Hohmann J. Tetrahedron 2012, 68: 8403-8407.

${ }^{37}$ Rédei D, Boros K, Forgó P, Molnár J, Kele Z, Pálinkó I, Pinke G, Hohmann J. Chem. Biodivers. 2015, 12: 12141221.

${ }^{38}$ Tsai JY, Rédei D, Forgó P, Li Y, Vasas A, Hohmann J, Wu CC. J. Nat. Prod. 2016, 79: 2658-2666.

39 Prenner G, Rudall PJ. Am. J. Bot. 2007, 94: 1612-1629.

${ }^{40}$ Horn JW, van Ee BW, Morawetz JJ, Riina R, Steinmann VW, Berry PE, Wurdack KJ. Mol. Phylogenet. Evol. 2012 , 63: 305-326. 
${ }^{41}$ Riina R, Peirson JA, Geltman DV, Molero J, Frajman B, Pahlevani A, Barres L, Morawetz JJ, Salmaki Y, Zarre S, Kryukov A, Bruyns PV, Berry PE. Taxon 2013, 62: 316-342.

42 Yang Y, Riina R, Morawetz JJ, Haevermans T, Aubriot X, Berry PE. Taxon 2012, 61: 764-789.

${ }^{43}$ Tutin TG, Heywood VH, Burges NA, Moore DM, Valentine DH, Walters SM, Webb DA, eds. Flora Europea, Vol 2. Cambridge: University Press 1968, pp. 213-226.

${ }^{44}$ Ozenda P. Flore et végétation du Sahara. In : CNRS (Ed.), Paris, 1991.

45 Pottier-Alapetite G. Flore de la Tunisie (Angiospermes-Dicotylédones). 2 volumes. Publications scientifiques tunisiennes, Ministère de l'Enseignement supérieur et de la Recherche Scientifique, Ministère de l'Agriculture, Tunis, 1979-1981.

${ }^{46}$ Vladimirov V, Petrova AS. Phytol. Balcanica 2009, 15: 343-345.

${ }^{47}$ Ramos MV, Demarco D, da Costa Souza IC, de Freitas CDT. Trends Plant. Sci. 2019, 24: 553-567.

48 Mithöfer A, Boland W. Annu. Rev. Plant. Biol. 2012, 63: 431-450.

${ }^{49}$ Ernst M, Nothias LF, van der Hooft JJJ, Silva RR, Saslis-Lagoudakis CH, Grace OM, Martinez-Swatson K, Hassemer G, Funez LA, Simonsen HT, Medema MH, Staerk D, Nilsson N, Lovato P, Dorrestein PC, Rønsted N. Front. Plant Sci. 2019, 10: 846.

50 Domsalla A, Melzig MF. Planta Med. 2008, 74: 699-711.

${ }^{51}$ Badgujar SB. J. Ethnopharmacol. 2014, 151: 733-739.

52 Sytwala S, Günther F, Melzig MF. Plant Physiol. Biochem. 2015, 95: 35-40.

53 Siritapetawee J, Limphirat W, Wongviriya W, Maneesan J, Samosornsuk W. Int. J. Biol. Macromol. 2018, 120: 1846-1854.

${ }^{54}$ Salomé Abarca LF, Klinkhamer PGL, Choi YH. Planta Med. 2019, 85: 856-858.

55 Bigoniya P, Shukla A, Singh CH. Int. J. Phytomed. 2010, 2: 240-254.

${ }^{56}$ Wang S, Liang H, Zhao Y, Wang G, Yao H, Kasimu R, Wu Z, Li Y, Huang J, Wang J. Fitoterapia 2016, 108 : 33-40.

${ }^{57}$ Akihisa T, Kithsiri Wijeratne EM, Tokuda H, Enjo F, Toriumi M, Kimura Y, Koike K, Nikaido T, Tezuka Y, Nishino H. J. Nat. Prod. 2002, 65: 158-162.

${ }^{58}$ Wang SY, Huang C, Sun RK, Lu LN, Liang HG, Gao L, Huang J, Wang JH, Yang BF. Phytochem. Lett. 2019, 29: 220224.

${ }^{59}$ Giner JL, Berkowitz JD, Andersson T. J. Nat. Prod. 2000, 63: 267-269.

${ }^{60}$ Fajardo-Sánchez E, Galiano V, Villalaín J. J. Biomol. Struct. Dyn. 2017, 35: 2688-2700.

61 Patel AV, Sumner S, Thompson HL, Blunden G, Wright D, Liu JF, Zan JF. Nat. Prod. Commun. 2013, 8: 63-65.

${ }^{62}$ Fattorusso E, Lanzotti E, Taglialatela-Scafati O, Tron GC, Appendino G. Eur. J. Org. Chem. 2002, 71-78.

${ }^{63}$ Xu J, Kang J, Cao X, Sun X, Yu S, Zhang X, Sun H, Guo Y. J. Agr. Food. Chem. 2015, 63: 5902-5910.

${ }^{64}$ Hua J, Liu Y, Xiao CJ, Jing SX, Luo SH, Li SH. Phytochemistry 2017, 136: 56-64.

${ }^{65}$ Deng YY, Qu B, Zhan ZL, Wang AQ, Zhou W, Jia MY, Hua J, Luo SH. Nat. Prod. Res. 2019, 29: 1-9.

${ }^{66}$ Baloch IB, Baloch MK, Baloch AK. Eur. J. Med. Chem. 2009, 44: 3188-3194.

${ }^{67}$ Krstić G, Anđelković B, Choi YH, Vajs V, Stević T, Tešević V, Gođevac D. Phytochemistry 2016, 131: 17-25.

${ }^{68}$ Evans FJ, Taylor SE. Prog. Chem. Org. Nat. Prod. 1983, 44: 1-99.

69 Urones JG, Barcala PB, Sexmero Cuadrado MJ, Marcos IS. Phytochemistry 1988, 27: 207-212.

${ }^{70}$ Marco JA, Sanz-Cervera, Yuste A. Phytochemistry 1997, 45: 563-570.

${ }^{71}$ Vogg G, Mattes E, Rothenburger J, Hertkorn N, Achatz S, Sandermann Jr. H. Phytochemistry 1999, 51: $289-295$.

72 Betancur-Galvis L, Palomares E, Marco JA, Estornell E. J. Ethnopharmacol. 2003, 85: 279-282.

73 Baloch IB, Baloch MK, Saqib QN. Helv. Chim. Acta 2005, 88: 3145-3150.

${ }^{74}$ Baloch IB, Baloch MK, Baloch AK. Planta Med. 2010, 76: 809-814.

75 Seip EH, Hecker E. Phytochemistry 1984, 23: 1689-1694.

${ }^{76}$ Fakunle CO, Connolly JD, Rycroft DS. J. Nat. Prod. 1989, 52: 279-283.

77 Marco JA, Sanz-Cervera JF, Checa J, Palomares E, Fraga BM. Phytochemistry 1999, 52: 479-485.

78 Betancur-Galvis L, Checa J, Marco JA, Estornell E. Planta Med. 2003, 69: 177-178.

${ }^{79}$ Corea G, Fattorusso E, Lanzotti V, Taglialatela-Scafati O, Appendino G, Ballero M, Simon PN, Dumontet C, Di Pietro A. J. Med. Chem. 2003, 46: 3395-3402. 
${ }^{80}$ Corea G, Fattorusso E, Lanzotti V, Taglialatela-Scafati O, Appendino G, Ballero M, Simon PN, Dumontet C, Di Pietro A. Bioorg. Med. Chem. 2003, 11: 5221-5227.

81 Jadranin M, Pešić M, Aljančić IS, Milosavljević SM, Todorović NM, Podolski-Renić A, Banković J, Tanić N, Marković I, Vajs VV, Tešević VV. Phytochemistry 2013, 86: 208-217.

82 Hua J, Liu YC, Jing SX, Luo SH, Li SH. Nat. Prod. Commun. 2015, 10: 2037-2039.

${ }^{83}$ Esposito M, Nothias LF, Nedev H, Gallard, JF, Leyssen P, Retailleau P, Costa J, Roussi F, lorga BI, Paolini J, Litaudon M. J. Nat. Prod. 2016, 79: 2873-2882.

${ }^{84}$ Esposito M, Nim S, Nothias LF, Gallard JF, Rawal MK, Costa J, Roussi F, Prasad R, Di Pietro A, Paolini J, Litaudon M. J. Nat. Prod. 2017, 80: 479-487.

${ }^{85}$ Krstić G, Jadranin M, Todorović NM, Pešić M, Stanković T, Aljančić IS, Tešević VV. Phytochemistry 2018, 148: 104-112.

${ }^{86}$ Durán-Peña MJ, Flores-Giubi ME, Botubol-Ares JM, Escobar-Montaño F, Macías-Sánchez AJ, Echeverri LF, Collado IG, Hernández-Galán R. Nat. Prod. Commun. 2017, 12: 671-673.

87 Zhao ND, Ding X, Song Y, Yang DQ, Yu HL, Adelakun TA, Qian WD, Zhang Y, Di YT, Gao F, Hao XJ, Li SH. J. Nat. Prod. 2018, 81: 1209-1218.

${ }^{88}$ Wang SY, Li GY, Zhang K, Wang HY, Liang HG, Huang C, Huang J, Wang JH, Yang BF. J. Asian Nat. Prod. Res. 2019, 21: 1075-1082.

${ }^{89}$ Vasas A, Rédei D, Csupor D, Molnár J, Hohmann J. Eur. J. Org. Chem. 2012, 27: 5115-5130.

${ }^{90}$ Yan N, Du Y, Liu X, Zhang H, Liu Y, Zhang P, Gong D, Zhang Z. Ind. Crops Prod. 2016, 83: 66-80.

${ }^{91}$ Vasas A, Hohmann J. Chem. Rev. 2014, 114: 8579-8612.

92 Rinner U. Eur. J. Org. Chem. 2015, 15: 3197-3219.

${ }^{93}$ Bathe U, Tissier A. Phytochemistry 2019, 161: 149-162.

${ }^{94}$ Hecker E. Cancer Res. 1968, 28: 2338-2349.

${ }^{95}$ Adolf W, Hecker E, Balmain A, Lhomme MF, Nakatani Y, Ourisson G, Ponsinet G, Pryce RJ, Santhanakrishnan TS, Matyukhina LG, Saltikova IA. Tetrahedron Lett. 1970, 11: 2241-2244.

96 Onwukaeme N, Rowan MG. Phytochemistry 1992, 31: 3479-3482.

97 Shavarda AL, Geltman DV. Rastitelnye Resursy 2017, 53: 163-195.

98 Tian Y, Xu W, Zhu C, Lin S, Guo Y, Shi J. J. Nat. Prod. 2013, 76: 1039-1046.

${ }^{99}$ Remy S, Olivon F, Desrat S, Blanchard F, Eparvier V, Leyssen P, Neyts J, Roussi F, Touboul D, Litaudon M. J. Nat. Prod. 2018, 81: 901-912.

100 Wang JX, Zheng LL, Gao F, Zhou XL. Fitoterapia 2019, 133: 212-218.

101 Duarte N, Ferreira MJU. Org. Lett. 2007, 9: 489-492.

102 Kupchan SM, Sigel CW, Matz MJ, Saenz Renauld JA, Haltiwanger RC, Bryan RF. J. Am. Chem. Soc. 1970, 92 : 4476-4477.

103 Zechmeister K, Brandl F, Hoppe W, Hecker E, Opferkuch HJ, Adolf W. Tetrahedron Lett. 1970, 47: 4075-4078.

104 King AJ, Brown GD, Gilday AD, Larson TR, Graham IA. Plant Cell 2014, 26: 3286-3298.

105 Shi QW, Su XH, Kiyota H. Chem. Rev. 2008, 108: 4295- 4327.

106 Valente C, Pedro M, Duarte A, Nascimento MSJ, Abreu PM, Ferreira MJU. J. Nat. Prod. 2004, 67: $902-904$.

107 Reis MA, André V, Duarte MT, Lage H, Ferreira MJU. J. Nat. Prod. 2015, 78: 2684-2690.

108 Wang LY, Wang NL, Yao XS, Miyata S, Kitanaka S. Chem. Pharm. Bull. 2003, 51: 935-941.

109 Pan Q, Ip FC, Ip NY, Zhu HX, Min ZD. J. Nat. Prod. 2004, 67: 1548-1551.

110 Wang LY, Wang NL, Yao XS, Miyata S, Kitanaka S. J. Nat. Prod. 2002, 65: 1246-1251.

111 Liu LG, Meng JC, Wu SX, Li XY, Zhao XC, Tan RX. Planta Med. 2002, 68: 244-248.

112 Shadi S, Saeidi H, Ghanadian M, Rahimnejad MR, Aghaei M, Ayatollahi SM, Choudhary MI. Nat. Prod. Res. 2015, 29: 607-614.

${ }^{113}$ Nothias-Scaglia LF, Gallard JF, Dumontet V, Roussi F, Costa J, lorga BI, Paolini J, Litaudon M. J. Nat. Prod. 2015, 78: 2423-2431.

${ }^{114}$ Lu ZQ, Guan SH, Li XN, Chen GT, Zhang JQ, Huang HL, Liu X, Guo DA. J. Nat. Prod. 2008, 71: 873-876.

115 Marco JA, Sanz-Cervera JF, Yuste A, Jakupovic J, Lex J. J. Org. Chem. 1996, 61: 1707-1709.

116 Marco JA, Sanz-Cervera JF, Yuste A, Jakupovic J. Phytochemistry 1997, 45: 137-140. 
${ }^{117}$ Hu R, Gao J, Rozimamat R, Aisa HA. Eur. J. Med. Chem. 2018, 146: 157-170.

118 Jakupovic J, Jeske F, Morgenstern T, Tsichritzis F, Marco JA, Berendsohn W. Phytochemistry 1998, 47: 15831600.

119 Marco JA, Sanz-Cervera JF, Yuste A, Jakupovic J. J. Nat. Prod. 1999, 62: 110-113.

${ }^{120}$ Hegazy ME, Mohamed Ael-H, Aoki N, Ikeuchi T, Ohta E, Ohta S. Phytochemistry 2010, 71: 249-253.

${ }^{121}$ Huang Y, Aisa HA. Helv. Chim. Acta 2010, 93: 1156-1161.

122 Appendino G, Jakupovic S, Tron GC, Jakupovic J, Milon V, Ballero M. J. Nat. Prod. 1998, 61: 749-756.

${ }^{123}$ Valente C, Ferreira MJU, Abreu PM, Gyémánt N, Ugocsai K, Hohmann J, Molnár J. Planta Med. 2004, 70: 8184.

${ }^{124}$ Zhu J, Wang R, Lou L, Li W, Tang G, Bu X, Yin S. J. Med. Chem. 2016, 59: 6353-6369.

125 Mai ZP, Ni G, Liu YF, Li L, Li JY, Yu DQ. Org. Lett. 2018, 20: 3124-3127.

${ }^{126}$ Su JC, Cheng W, Song JG, Zhong YL, Huang XJ, Jiang RW, Li YL, Li MM, Ye WC, Wang Y. J. Nat. Prod. 2019, 82: 2818-2827.

127 Marco JA, Sanz-Cervera JF, Yuste A, Jakupovic J, Jeske F. Phytochemistry 1998, 47: 1621-1630.

${ }^{128}$ Mai ZP, Ni G, Liu YF, Li L, Shi GR, Wang X, Li JY, Yu DQ. Sci. Rep. 2017, 7: 4922.

129 Flores-Giubi ME, Durán-Peña MJ, Botubol-Ares JM, Escobar-Montaño F, Zorilla D, Macías-Sánchez AJ, Hernández-Galán R. J. Nat. Prod. 2017, 80: 2161-2165.

130 Mai ZP, Ni G, Liu YF, Li YH, Li L, Li JY, Yu DQ. J. Org. Chem. 2018, 83: 167-173.

${ }^{131}$ Li W, Tang YQ, Chen SX, Tang GH, Gan LS, Li C, Rao Y, Huang ZS, Yin S. J. Nat. Prod. 2019, 82: 412-416.

132 Mai ZP, Ni G, Liu Y, Zhang Z, Li L, Chen N, Yu D. Acta Pharm. Sinica B 2018, 8: 805-817.

133 Li J, Li HH, Wang WQ, Song WB, Wang YP, Xuan LJ. Fitoterapia 2018, 128: 102-111.

134 Hasan A, Liu GY, Hu R, Aisa HA. J. Nat. Prod. 2019, 82: 724-734.

${ }^{135}$ Fang Y, Sun J, Zhong X, Hu R, Gao J, Duan G, Ji C, Chen L, Zhang W, Miao C, Aisa HA, Zhang X. Pharm. Res. 2018, 129: 388-399.

${ }^{136}$ Rawal MK, Shokoohinia Y, Chianese G, Zolfaghari B, Appendino G, Taglialatela-Scafati O, Prasad R, Di Pietro A. J. Nat. Prod. 2014, 77: 2700-2706.

${ }^{137}$ Aljančić IS, Pešić M, Milosavljević SM, Todorović NM, Jadranin M, Milosavljević G, Povrenović D, Banković J, Tanić N, Marković ID, Ruždijić S, Vajs VE, Tešević VV. J. Nat. Prod. 2011, 74: 1613-1620.

138 Reis MA, Ahmed OB, Spengler G, Molnár J, Lage H, Ferreira MJU. Phytomedicine 2016, 23: 968-978.

139 Duarte N, Járdánházy A, Molnár J, Hilgeroth A, Ferreira MJU. Bioorg. Med. Chem. 2008, 16: 9323-9330.

${ }^{140}$ Ghanadian M, Saeidi H, Aghaei M, Rahiminejad MR, Ahmadi E, Ayatollahi SM, Choudhary MI, Bahmani B. Phytochem. Lett. 2015, 12: 302-307.

${ }^{141}$ Lanzotti V, Barile E, Scambia G, Ferlini C. Fitoterapia 2015, 104: 75-79.

142 Pešić M, Banković J, Aljančić IS, Todorović NM, Jadranin M, Vajs VE, Tešević VV, Vučković I, Momčilović M, Marković ID, Tanić N, Ruždijić S. Food Chem. Tox. 2011, 49: 3165-3173.

143 Miglietta A, Gabriel L, Appendino G, Bocca C. Cancer Chemother. Pharmacol. 2003, 51: 67-74.

144 Nothias-Scaglia LF, Retailleau P, Paolini J, Pannecouque C, Neyts J, Dumontet V, Roussi F, Leyssen P, Costa J, Litaudon M. J. Nat. Prod. 2014, 77: 1505-1512.

145 Bedoya LM, Márquez N, Martínez N, Gutiérrez-Eisman S, Álvarez A, Calzado MA, Rojas JM, Appendino G, Muñoz E, Alcamí J. Biochem. Pharmacol. 2009, 77: 965-978.

146 Geng D, Yi LT, Shi Y, Min ZD. Chin. J. Nat. Med. 2015, 13: 704-706.

147 Mongkolvisut W, Sutthivaiyakit S. J. Nat. Prod. 2007, 70: 1434-1438.

${ }^{148}$ Hadi V, Hotard M, Ling T, Salinas YG, Palacios G, Connelly M, Rivas F. Eur. J. Med. Chem. 2013, 65: 376-380.

149 Zhou B, Wu Y, Dalal S, Cassera MB, Yue JM. J. Nat. Prod. 2016, 79: 1952-1961.

150 Lee JW, Jin Q, Jang H, Lee D, Han SB, Kim Y, Hong JT, Lee MK, Hwang BY. Bioorg. Med. Chem. Lett. 2016, 26: 3351-3354.

${ }^{151}$ Chen H, Wang H, Yang B, Jin DQ, Yang S, Wang M, Xu J, Ohizumi Y, Guo Y. Fitoterapia 2014, 95: 133-138.

152 Wang H, Liu Y, Zhang J, Xu J, Cui CA, Guo Y, Jin DQ. Neurosci. Lett. 2016, 612: 149-154.

153 Wan LS, Shao LD, Fu L, Xu J, Zhu GL, Peng XR, Li XN, Li Y, Qiu MH. Org. Lett. 2016, 18: 496-499.

154 Barla A, Birman H, Kültür Ş, Öksüz S. Turk. J. Chem. 2006, 30: 325-332. 
155 Öksüz S, Gürek F, Yang SW, Lin LZ, Cordell GA, Pezzuto JM, Wagner H, Lotter H. Tetrahedron 1997, 53: 32153222.

156 Jakupovic J, Morgenstern T, Marco JA, Berendsohn W. Phytochemistry 1998, 47: 1611-1619.

${ }^{157}$ Abdelgaleil SAM, Kassem SMI, Doe M, Baba M, Nakatani M. Phytochemistry 2001, 58: 1135-1139.

158 Barile E, Lanzotti V. Org Lett. 2007, 9: 3603-3606.

${ }^{159}$ Madureira AM, Gyémánt N, Ascenso JR, Abreu PM, Molnár J, Ferreira MJU. J. Nat. Prod. 2006, 69: 950-953.

160 Alder RW, East SP. Chem. Rev. 1996, 96: 2097-2111.

161 Braekman JC, Daloze D, Dupont A, Pasteels J, Tursch B. Tetrahedron Lett. 1980, 21: 2761-2762.

162 Wu QC, Tang YP, Ding AW, You FQ, Zhang L, Duan JA. Molecules 2009, 14: 4454-4475.

163 Zani CL, Marston A, Hamburger M, Hostettmann K. Phytochemistry 1993, 34: 89-95.

164 Yan XL, Sang J, Chen SX, Li W, Tang GH, Gan LS, Yin S. Org. Lett. 2019, 21: 4128-4131.

165 McKerall SJ, Jørgensen L, Kuttruff CA, Ungeheuer F, Baran PS. J. Am. Chem. Soc. 2014, 136: 5799-5810.

166 https://www.ema.europa.eu/en/documents/assessment-report/picato-epar-public-assessmentreport_en.pdf (accessed on 28. 01. 2018.)

167 Sorg B, Schmidt R, Hecker E. Carcinogenesis 1987, 8: 1-4.

168 Alchin DR. Dermatol. Ter. (Heidelb.) 2014, 4: 157-164.

${ }^{169}$ Racke FK, Baird M, Barth RF, Huo T, Yang W, Gupta N, Weldon M, Rutledge H. PLOS ONE 2012, 7: e51059, doi: 10.1371/journal.pone.0051059.

${ }^{170}$ Shi J, Li Z, Nitoda T, Izumi M, Kanzaki H, Baba N, Kawazu K, Nakajima S. Z. Naturforsch. C. J. Biosci. 2008, 63: 59-65.

${ }^{171}$ Huang YS, Lu Y, Chen CH, Lee KH, Chen DF. J. Nat. Prod. 2019, 82: 1587-1592.

172 Yang $H$, Li X, Yang X, Lu P, Wang Y, Jiang Z, Jiang Z, Pan H, Zhao L, Zhu Y, Khan IU, Shen Y, Lu H, Zhang T, Jiang G, Ma Z, Wu H, Zhu H. Antivir. Res. 2019, 169: 104555

${ }^{173}$ Wang HB, Chen W, Zhang YY, Wang XY, Liu LP, Tong LJ, Chen Y. Fitoterapia 2013, 91: 211-216.

174 Oh S, Oh HW, Lee HR, Yoon SY, Oh SR, Ko YE, Yoo N, Jeong J, Kim JW. J. Sci. Food. Agr. 2016, 96: 2635-2640.

175 Pohl R, Janistyn B, Nahrstedt A. Planta Med. 1975, 27: 301-303.

${ }^{176}$ Amar Z, Labib SN, Noureddine G, Salah R. Der Pharm. Lett. 2012, 4: 1438-1444.

177 Boudiar T, Hichem L, Khalfallah A, Kabouche A, Kabouche Z, Brouard I, Bermejo J, Bruneau C. Nat. Prod. Commun. 2010, 5: 35-37.

${ }^{178}$ Haba H, Lavaud C, Harkat H, Alabdul Magid A, Marcourt L, Benkhaled M. Phytochemistry 2007, 68: 1255-1260.

179 Haba H, Lavaud C, Marcourt L, Long C, Harkat H. Benkhaled M. Biochem. Syst. Ecol. 2009, 37: 504-508.

180 Haba H, Marcourt L, Benkhaled M, Long C. Nat. Prod. Commun. 2013, 8: 1519-1522.

${ }^{181}$ Ahmed AA, Gherraf N, El-Bassuony AA, Rhouati S, Gad MH, Ohta S, Hirata T. Nat. Prod. Commun. 2006, 1: 273279.

182 El-Bassuony AA. Asian J. Chem. 2007, 6: 4553-4562.

183 Lakhdari W, Dehliz A, Acheuk F, Mlik R, Hammi H, Doumandji-Mitiche B, Gheriani S, Berrekbia M, Guermit K, Chergui S. J. Med. Plants Stud. 2016, 4: 204-211.

${ }^{184}$ Valente C, Pedro M, Ascenso A, Abreu PM, Nascimiento MSJ, Ferreira MJU. Planta Med. 2004, 70: $244-249$.

${ }^{185}$ Valente I, Reis M, Duarte N, Serly J, Molnár J, Ferreira MJU. J. Nat. Prod. 2012, 75: 1915-1921.

${ }^{186}$ Liu C, Liao ZX, Liu SJ, Qu YB, Wang HS. Fitoterapia 2014, 96: 33-38.

187 Yamamura S, Shizuri Y, Kosemura S, Ohtsuka J, Tayama T, Ohba S, Ito M, Saito Y, Terada Y. Phytochemistry 1989, 28: 3421-3436.

${ }^{188}$ Corea G, Fattorusso C, Fattorusso E, Lanzotti V. Tetrahedron 2005, 61: 4485-4494.

189 Gotta H, Adolf W, Opferkuch HJ, Hecker E. Z Naturforsch B 1984, 39: 683-694.

190 Jakupovic J, Morgenstern T, Bittner M, Silva M. Phytochemistry 1998, 47: 1601-1609.

${ }^{191}$ Strack D, Heilmann J, Mömken N, Wray W. Phytochemistry 1988, 27: 3517-3521.

192 Markham KR, Ternai B, Stanley R, Geiger H, Mabry TJ. Tetrahedron 1978, 34: 1389-1397.

${ }^{193}$ Mok SY, Lee S. Food Chem. 2013, 136: 969-974.

194 Panizza BJ, de Souza P, Cooper A, Roohullah A, Karapetis CS, Lickliter JD. EBioMedicine 2019, 50: 433-441.

195 https://clinicaltrials.gov/ct2/show/study/NCT00804154 
${ }^{196}$ Brown CD. Pharmaceuticals (Basel) 2016, 9: 47.

197 https://clinicaltrials.gov/ct2/show/NCT04044742

${ }^{198}$ Barile E, Borriello M, Di Pietro A, Doreau A, Fattorusso C, Fattorusso E, Lanzotti V. Org. Biomol. Chem. 2008, 6: 1756-1762.

${ }^{199}$ Valente C, Ferreira MJU, Abreu PM, Pedro M, Cerqueira F, Nascimiento MSJ. Planta Med. 2003, 69: 361-366.

200 Sahai R, Rastogi RP, Jakupovic J, Bohlmann F. Phytochemistry 1981, 20: 1665-1667.

${ }^{201}$ Tutin TG, Heywood VH, Burges NA, Moore DM, Valentine DH, Walters SM, Webb DA, eds. Flora Europea, Vol 2. Cambridge: University Press 1968, pp. 213-216.

202 Hashimoto N, Yamashita T, Tsuruzoe N. Pharmacol. Res. 2006, 54: 136-141.

${ }^{203}$ Walsh KB. Front. Pharmacol. 2011, 2, Article 64, 1-8.

204 Vandenberg JI, Perry MD, Perrin MJ, Mann SA, Ke Y, Hill AP. Physiol. Rev. 2012, 92: 1393-1478.

${ }^{205}$ Sanguinetti MC, Tristani-Firouzi M. Nature 2006, 440: 463-469.

${ }^{206}$ Whitebread S, Hamon J, Bojanic D, Urban L. Drug Discov. Today 2005, 10: 1421-1433.

${ }^{207}$ Vasas A, Forgó P, Orvos P, Tálosi L, Csorba A, Pinke G, Hohmann J. J. Nat. Prod. 2016, 26: 1990-2004.

${ }^{208}$ Schneider G, Kiss A, Mernyák E, Benke Zs, Wölfling J, Frank É, Bózsity N, Gyovai A, Minorics R, Zupkó I. Steroids 2016, 105: 113-120. 


\section{Acknowledgements}

I am grateful to Prof. Judit Hohmann for providing me with the opportunity to conduct my scientific work in the Department of Pharmacognosy, University of Szeged, during 2013-2018. I would like to express my deepest appreciation to my supervisors, Dr. Dóra Rédei and Prof. Judit Hohmann for their guidance and constant support. Writing this thesis would not have been possible without their persistent help, warm encouragement, and constructive criticism. The helpful attitude and honest enthusiasm of Prof. Judit Hohmann greatly inspired me when she introduced me to the field of NMR spectroscopy.

I would like to express my sincere thanks to Dr. Gusztáv Jakab (Institute of Environmental Sciences, Szent István University, Szarvas, Hungary), Dr. Zoltán Barina (Department of Botany, Hungarian Natural History Museum, Budapest, Hungary), Prof. Mohamed Chaieb (Department of Biology and Ecology of Arid Land, University of Sfax, Sfax, Tunisia), and Prof. Gyula Pinke (Department of Botany, University of West Hungary, Mosonmagyaróvár, Hungary) for the identification and collection of the plant materials.

I also wish to thank Dr. Péter Forgó (Department of Chemistry and Food Chemistry, Eszterházy Károly University, Eger, Hungary) for the NMR measurements; Attila Csorba (Institute of Plant Biology, Biological Research Centre, Szeged, Hungary) for the HRESIMS measurements; Dr. Petra Bombicz, Dr. Krisztina Bereczki (Chemical Crystallography Research Laboratory, Research Centre for Natural Sciences, Hungarian Academy of Sciences, Budapest, Hungary) and Dr. Pierre Fertey (Synchrotron SOLEIL L'Orme des Merisiers - Saint Aubin, Gif-sur-Yvette Cedex, France) for the X-ray data; Dr. Péter Orvos (Rytmion Ltd., Szeged, Hungary, and Department of Pharmacology and Pharmacotherapy, University of Szeged, Szeged, Hungary) for the investigations of diterpenoids on GIRK and hERG channels; Dr. Annamária Kincses, Dr. Gabriella Spengler, and Dr. Katalin Burián (Department of Medical Microbiology and Immunobiology, University of Szeged, Szeged, Hungary) for testing the compounds for their MDR modulating and cytotoxic activities; and Dr. István Zupkó (Department of Pharmacodynamics and Biopharmacy, University of Szeged, Szeged, Hungary) for measuring the antiproliferative activity of plant extracts.

I am indebted to Dr. Balázs Dankó for teaching me how to use the NMR instrument, and how to process NMR data. My special thanks is due to the staff members and laboratory personnel, especially to Erzsébet Berta and Anna Nagy who helped me so generously in the laboratory. I would also like to thank my colleagues, Dr. Andrea Vasas, Dr. Katalin Veres, and Dr. Dezsö Csupor, who have always provided me with help, advice, and positive reassurance. I am grateful to Dr. Dóra Bokor for proofreading my thesis. 
I am extremely grateful to my family and to my love of life, Dr. Fanni Fekete for giving me so much emotional support, and for standing by me through thick and thin.

This work was supported by the project GINOP-2.3.2-15-2016-00012 (New ways in the natural productbased drug discovery-system metabolomic approaches to discover biologically active terpenoids of herbal and microbial origin). 